In cooperation with the City of Houston

\title{
Estimated Effects on Water Quality of Lake Houston From Interbasin Transfer of Water From the Trinity River, Texas
}

Water-Resources Investigations Report 00-4082

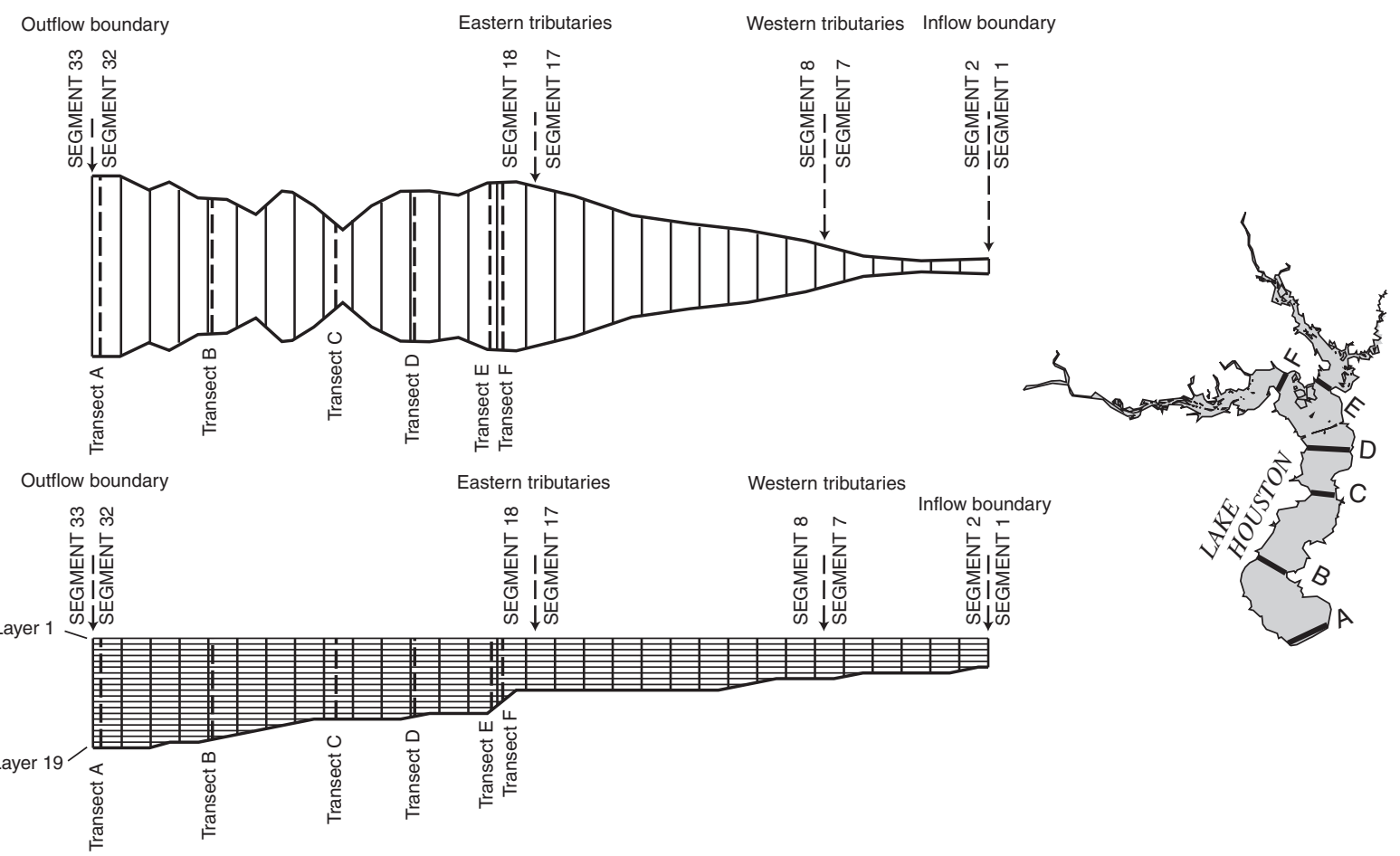

U.S. Department of the Interior U.S. Geological Survey 
U.S. Department of the Interior

U.S. Geological Survey

\section{Estimated Effects on Water Quality of Lake Houston From Interbasin Transfer of Water From the Trinity River, Texas}

By Fred Liscum and Jeffery W. East

U.S. GEOLOGICAL SURVEY

Water-Resources Investigations Report 00-4082

In cooperation with the City of Houston

Austin, Texas

2000 


\section{U.S. DEPARTMENT OF THE INTERIOR}

Bruce Babbitt, Secretary

\section{U.S. GEOLOGICAL SURVEY}

Charles G. Groat, Director

Any use of trade, product, or firm names is for descriptive purposes only and does not imply endorsement by the U.S. Government.

For additional information write to

\section{District Chief}

U.S. Geological Survey

8027 Exchange Dr.

Austin, TX 78754-4733

E-mail: dc_tx@usgs.gov

Copies of this report can be purchased from

U.S. Geological Survey

Branch of Information Services

Box 25286

Denver, CO 80225-0286

E-mail: infoservices@usgs.gov 


\section{CONTENTS}

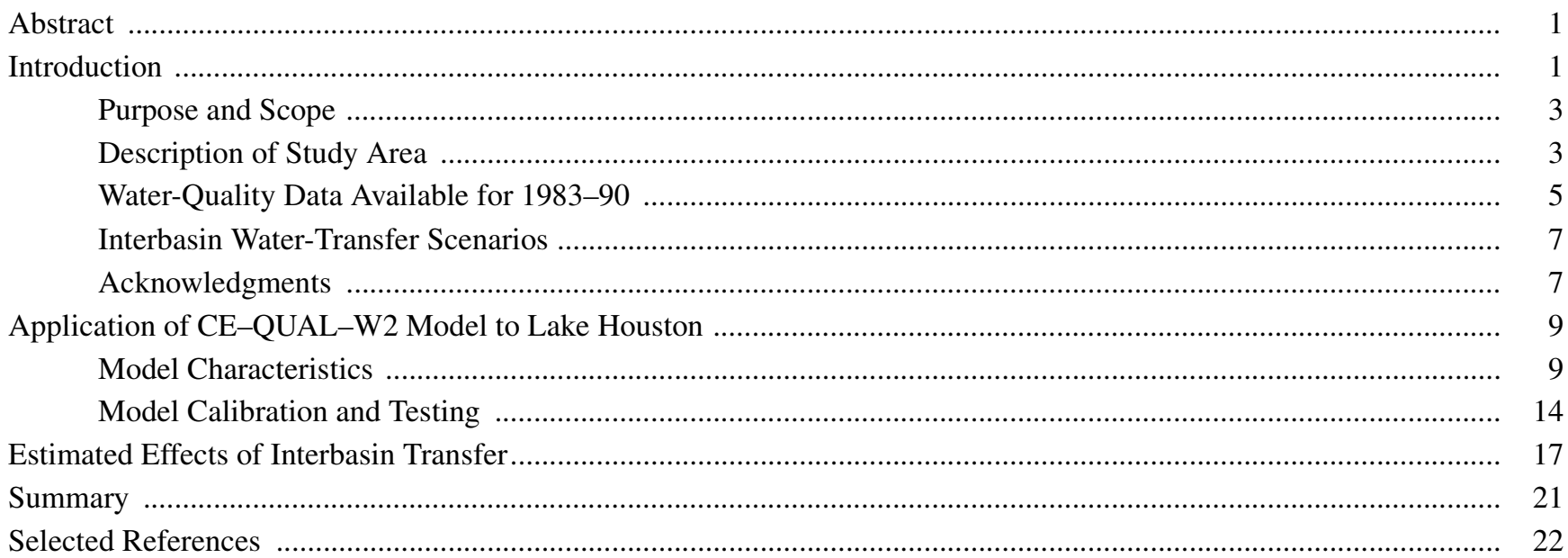

\section{FIGURES}

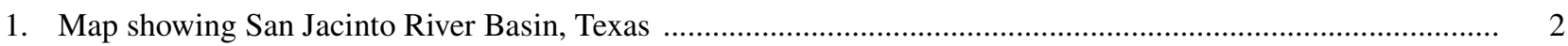

2. Map showing location of study area and data-collection sites ..................................................................... 4

3. Schematic showing views of Lake Houston as represented in CE-QUAL-W2 model: (a) Plan view of surface layer; (b) Longitudinal cross-section view

4. Graphs showing water-quality properties and constituents at segments 19 and 32 in Lake Houston for selected dates:

a. Water temperature as computed during model calibration .................................................................. 23

b. Water temperature as computed during model test run ....................................................................... 24

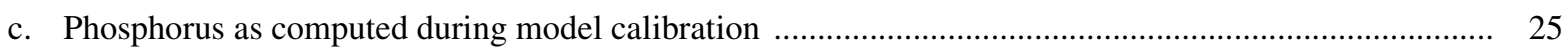

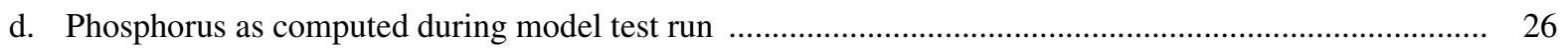

e. Ammonia nitrogen as computed during model calibration ............................................................... 27

f. Ammonia nitrogen as computed during model test run ........................................................................ 28

g. Nitrite plus nitrate nitrogen as computed during model calibration .................................................. 29

h. Nitrite plus nitrate nitrogen as computed during model test run ......................................................... 30

i. Algal biomass as computed during model calibration .................................................................... 31

j. Algal biomass as computed during model test run ..................................................................... 32

k. Dissolved oxygen as computed during model calibration .............................................................. 33

1. Dissolved oxygen as computed during model test run ...................................................................... 34

$\mathrm{m}$. Total dissolved solids as computed during model calibration ....................................................... 35

n. Total dissolved solids as computed during model test run .............................................................. 36

o. Labile dissolved organic matter as computed during model calibration ................................................... 37

p. Labile dissolved organic matter as computed during model test run .................................................. 38

q. Refractory dissolved organic matter as computed during model calibration ......................................... 39

r. Refractory dissolved organic matter as computed during model test run ............................................. 40

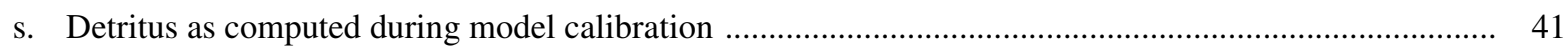

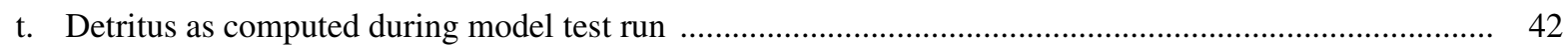

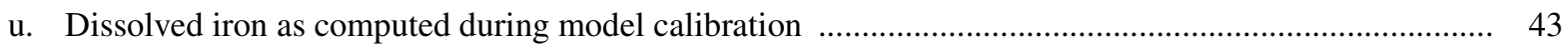

v. Dissolved iron as computed during model test run ................................................................................. 44 
5. Graphs showing simulated volume-weighted daily mean water-quality properties and constituents for segment 32 in Lake Houston using base dataset and six water-transfer scenarios for low- and high-flow years:
a. Water temperature
b. Phosphorus

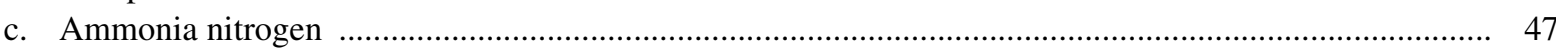

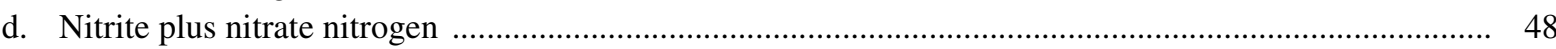

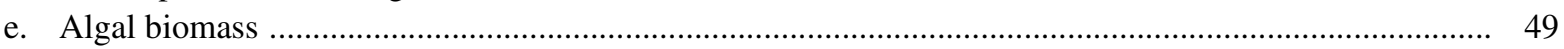

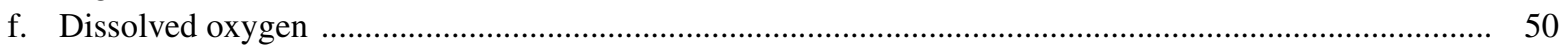

\title{
TABLES
}

1. Surface-water-quality sampling sites in Lake Houston, Trinity River, and tributaries to Lake Houston ............ 6

2. Summary of flow for six water-transfer scenarios, 1985-90, Trinity River into Lake Houston ......................... 8

3. Selected coefficients and constants determined for Lake Houston application of CE-QUAL-W2 .................... 12

4. Volume-weighted daily means computed for observed and simulated data for selected properties and constituents at segments 19 and 32 during calibration and test years .................................................... 16

5. Summary of reliability index computed for selected properties and constituents at segments 19 and 32 during calibration and test years

6. Summary of compatibility index for volume-weighted daily mean properties and constituents simulated for base dataset and for six water-transfer scenarios at segment 32 in Lake Houston, during selected simulation periods

7. Summary of percent change between volume-weighted mean properties and constituents simulated for base dataset and for six water-transfer scenarios at segment 32 in Lake Houston, 1985-90

\section{VERTICAL DATUM}

Sea level: In this report "sea level" refers to the National Geodetic Vertical Datum of 1929 (NGVD of 1929)—a geodetic datum derived from a general adjustment of the first-order level nets of both the United States and Canada, formerly called "Mean Sea Level of 1929."

\author{
Abbreviations: \\ acre-ft, acre-feet \\ $\mathrm{ft}^{3} / \mathrm{s}$, cubic feet per second \\ ${ }^{\circ} \mathrm{C}$, degrees Celsius \\ ${ }^{\circ} \mathrm{F}$, degrees Fahrenheit \\ $\mathrm{ft}$, feet \\ in., inches \\ $\mathrm{m}$, meters \\ mi, miles \\ $\mathrm{mi}^{2}$, square miles \\ $\mathrm{mi} / \mathrm{hr}$, miles per hour
}




\title{
Estimated Effects on Water Quality of Lake Houston From Interbasin Transfer of Water From the Trinity River, Texas
}

\author{
By Fred Liscum and Jeffery W. East
}

\begin{abstract}
The City of Houston is considering the transfer of water from the Trinity River to Lake Houston (on the San Jacinto River) to alleviate concerns about adequate water supplies for future water demands. The U.S. Geological Survey, in cooperation with the City of Houston, conducted a study to estimate the effects on the water quality of Lake Houston from the transfer of Trinity River water.
\end{abstract}

A water-quality model, CE-QUAL-W2, was used to simulate six water-quality properties and constituents for scenarios of interbasin transfer of Trinity River water. Three scenarios involved the transferred Trinity River water augmenting streamflow in the East Fork of Lake Houston, and three scenarios involved the transferred water replacing streamflow from the West Fork of the San Jacinto River.

The estimated effects on Lake Houston were determined by comparing volume-weighted daily mean water temperature, phosphorus, ammonia nitrogen, nitrite plus nitrate nitrogen, algal biomass, and dissolved oxygen simulated for each of the transfer scenarios to simulations for a base dataset. The effects of the interbasin transfer on Lake Houston do not appear to be detrimental to water temperature, ammonia nitrogen, or dissolved oxygen. Phosphorus and nitrite plus nitrate nitrogen showed fairly large changes when Trinity River water was transferred to replace West Fork San Jacinto River streamflow. Algal biomass showed large decreases when Trinity River water was transferred to augment East Fork Lake Houston streamflow and large increases when Trinity River water was transferred to replace West Fork San Jacinto River streamflow. Regardless of the scenario simulated, the model indicated that light was the limiting factor for algal biomass growth.

\section{INTRODUCTION}

Lake Houston on the San Jacinto River is a reservoir currently (1999) used as a water supply by the City of Houston, Texas (fig. 1). Because of concerns about adequate water supplies from Lake Houston to meet future water demands, the City of Houston is considering the transfer of water from adjacent or other nearby drainage basins to Lake Houston. The Trinity River is being considered as one of the potential sources for the transferred water. The water that would be transferred into Lake Houston could have different chemical and biological properties and constituents than the water currently supplied to the lake from its surrounding drainage basin. These properties and constituents are documented in Liscum and others (1999). Consequently, the introduction of Trinity River water into Lake Houston has the potential to substantially change or affect the current water quality of the lake. In addition, it is also possible that water could be exported from the Lake Houston watershed to augment water supplies in developing areas that are located west of the City of Houston. On the basis of these possible scenarios, the City of Houston needs to identify and assess the types and relative magnitude of water-quality changes that could occur to ensure that the water quality of Lake Houston is not degraded. This study was conducted by the U.S. Geological Survey (USGS), in cooperation with the City of Houston, to determine potential effects on the water quality of Lake Houston from interbasin transfer of water from the Trinity River. 


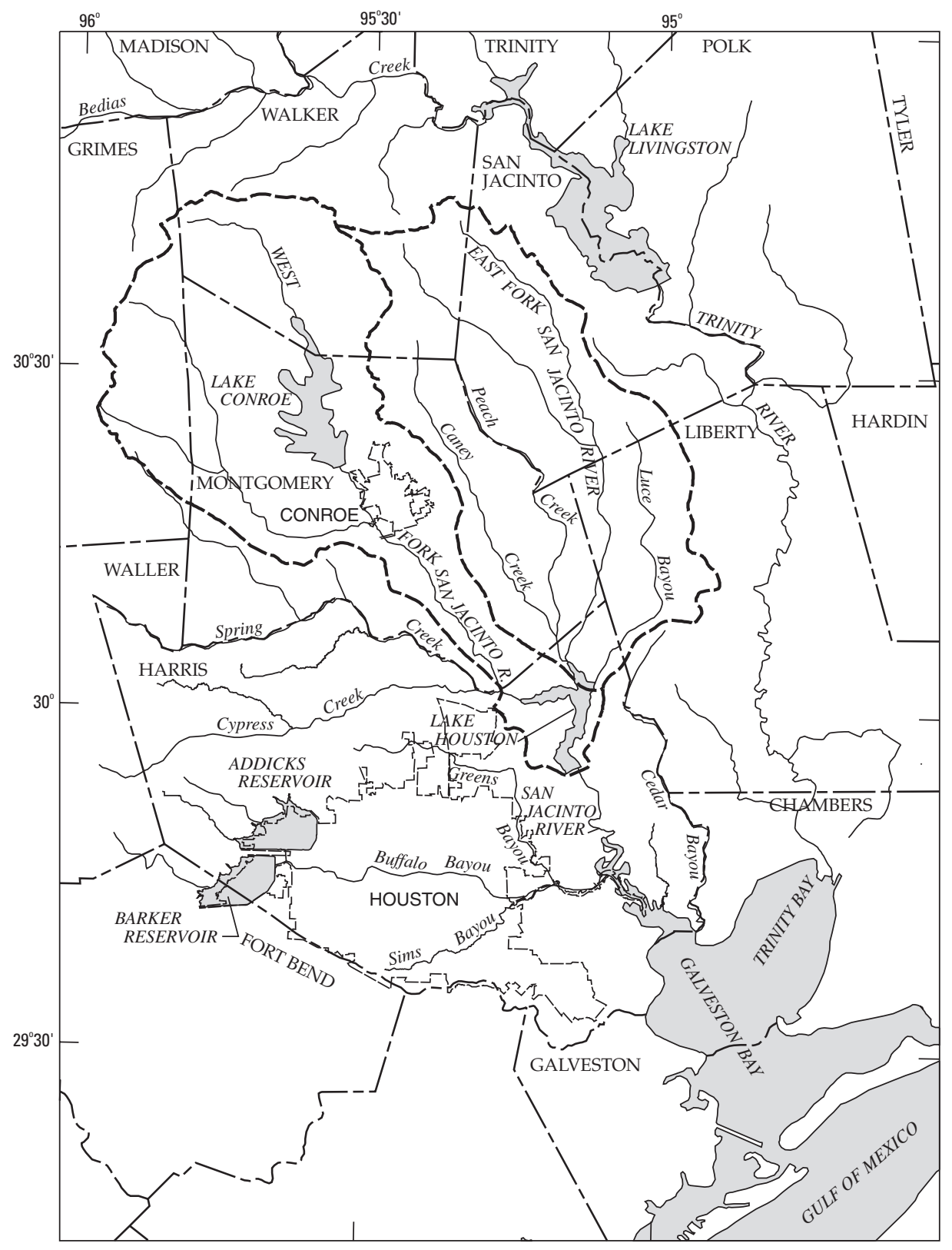

Base from U.S. Geological Survey

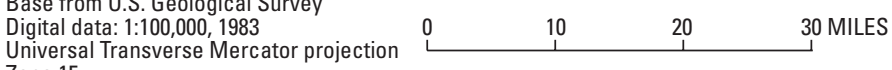

Zone 15

EXPLANATION

- - - Basin boundary

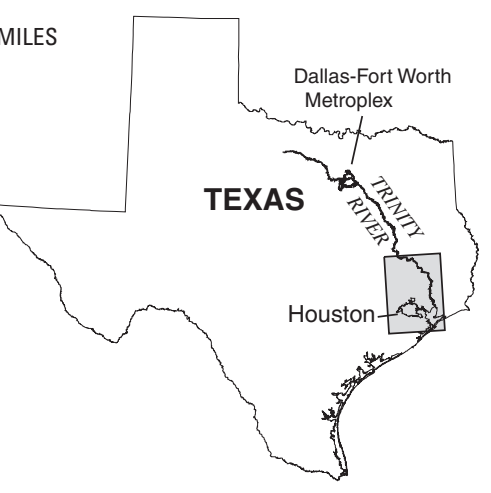

LOCATION MAP

Figure 1. San Jacinto River Basin, Texas. 


\section{Purpose and Scope}

The purpose of this report is to present the estimated effects on selected chemical and biological properties and constituents of Lake Houston that could result from interbasin transfer of water from the Trinity River. The City of Houston is concerned that Lake Houston has a strong potential for eutrophication, on the basis of nutrient inputs. These concerns are addressed by a study of water-quality changes as estimated using CE-QUAL-W2, a reservoir water-quality model developed by the U.S. Army Corps of Engineers (Cole and Buchak, 1995), for the following targeted properties and constituents: water temperature, selected nutrients (phosphorus, ammonia nitrogen, and nitrite plus nitrate nitrogen), algal biomass, and dissolved oxygen. To model these six targeted properties and constituents, five additional constituents must be calibratedtotal dissolved solids, labile dissolved organic matter (DOM), refractory DOM, detritus, and iron. The model allows for an evaluation of the primary limiting factors affecting eutrophication-nutrients (nitrogen or phosphorus) or light. The report includes an overview of the selected water-quality model, a summary of model calibration and testing, and a comparison of estimated water-quality effects for different interbasin-transfer scenarios. The effects of the transfer of Trinity River water on Lake Houston water quality were estimated using reservoir model simulations for January 1985September 1990. Inputs to the model were defined for the Lake Houston watershed and for the Trinity River using data collected during 1983-90 (Liscum and others, 1999). Pertinent data concerning water withdrawals from Lake Houston for the selected period also were used to configure the model.

\section{Description of Study Area}

Lake Houston is an impoundment located on the San Jacinto River, approximately 25 mi east-northeast of downtown Houston, in southeast Texas (fig. 2). Lake Houston was constructed by the City of Houston as a water supply for Houston, for the Houston-Baytown area industrial complex, and for local irrigators. The drainage basin for Lake Houston is $2,828 \mathrm{mi}^{2}$. The dam closure was completed on April 9, 1954. The dam forming the reservoir consists of two earthfill embankment sections and a 3,160-ft-long uncontrolled concrete spillway midway between the embankment sections, for a total length of 12,100 ft. Storage capacity of Lake
Houston at the spillway crest ( $43.8 \mathrm{ft}$ above sea level) is 146,700 acre-ft with a surface area of 12,240 acres. Mean depth for Lake Houston is $12 \mathrm{ft}$ with a maximum depth of about $50 \mathrm{ft}$. Theoretical residence time computed for Lake Houston varies with flow conditions from a maximum of about 400 days during extreme low flows (when the only withdrawals are by the City of Houston) to a minimum of about 0.5 day during extreme high flows. Theoretical residence time for average flow conditions is computed to be about 40 days.

The lake has two main inflow branches or forks. The eastern branch (East Fork) drains a mainly non-urbanized rural watershed, and the western branch (West Fork) drains a more urbanized drainage basin. The major tributaries that drain into the East Fork are the East Fork San Jacinto River, Caney Creek, Peach Creek, and Luce Bayou, which drain about $935 \mathrm{mi}^{2}$ (about 33 percent of the Lake Houston drainage basin). The major tributaries that drain into the West Fork are the West Fork San Jacinto River, Spring Creek, and Cypress Creek, which drain about 1,725 $\mathrm{mi}^{2}$ (about 61 percent of the drainage basin). The part of the watershed immediately surrounding Lake Houston below the tributary inflows drains about 6 percent of the watershed.

Land use in the Lake Houston drainage basin during the data-collection period was about 73 percent forest and about 14 percent pasture. Other land uses in the basin included gravel operations, oil production, agriculture, and urban. The East Fork tributary subbasin was predominantly agricultural, and the West Fork tributary subbasin was agricultural and urban (Matty and others, 1987). Other major land uses in the West Fork tributary subbasin included the Houston Intercontinental Airport (west of the lake), gravel operations, and transportation corridors (Bedient and others, 1980). The most active urban development during the study period occurred in the West Fork tributary subbasin along the lower part of the Cypress Creek watershed (fig. 2).

The climate of the study area is characterized by short mild winters, long hot summers, high relative humidity, and prevailing southeasterly winds. Annual precipitation in the Lake Houston drainage basin averages about 40 to 47 in. (Kingston, 1991). The temperatures typically range from a mean minimum of about $46^{\circ} \mathrm{F}\left(8^{\circ} \mathrm{C}\right)$ in January to a mean maximum of about $93{ }^{\circ} \mathrm{F}\left(34{ }^{\circ} \mathrm{C}\right)$ in July (Kingston, 1991). Wind speed 


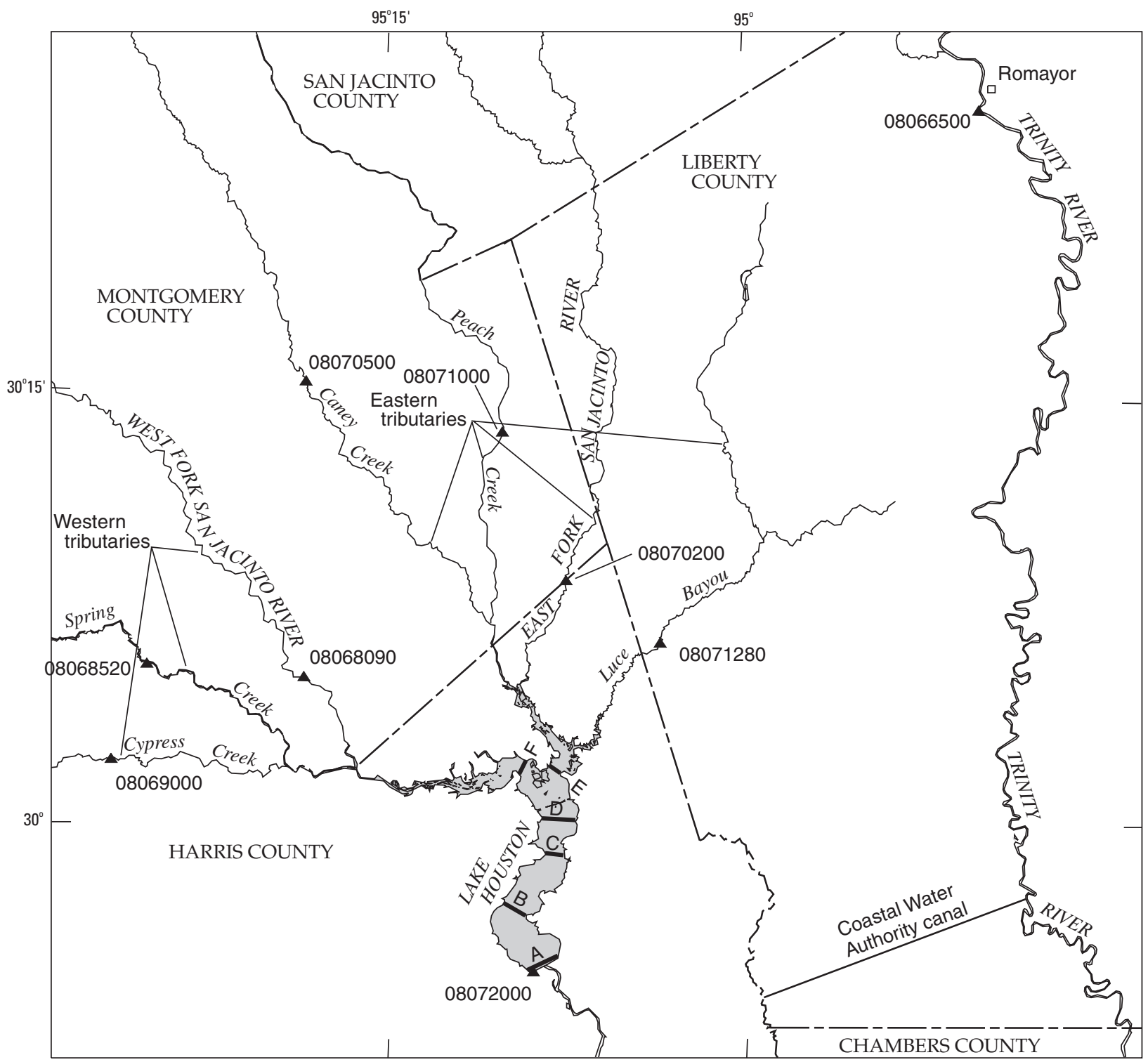

Base from U.S. Geological Survey Digital data: 1:100,000, 1983

Universal Transverse Mercator projection

Zone 15

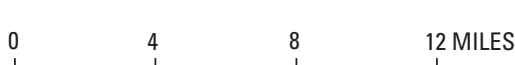

EXPLANATION

A Water-quality sampling transect

08072000_ USGS streamflow-gaging station and number

MILES

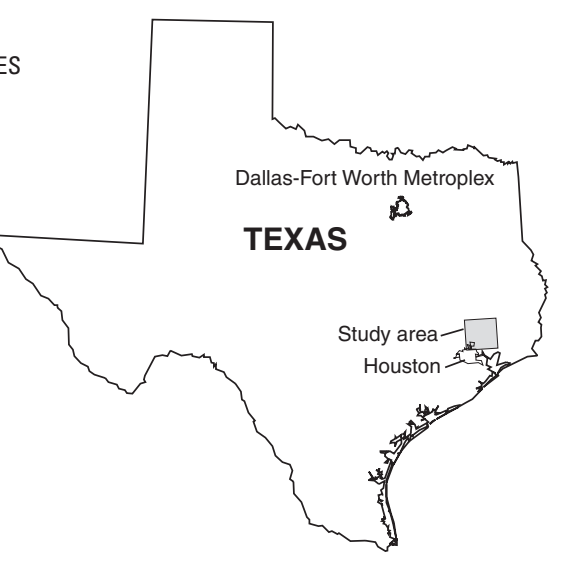

LOCATION MAP

Figure 2. Location of study area and data-collection sites. 
averages about $8 \mathrm{mi} / \mathrm{hr}$ and is from the south-southeast nearly the entire year (Baca and others, 1982; HoustonGalveston Area Council, 1984).

The Trinity River originates north of the DallasFort Worth metroplex, about 300 mi north-northwest of Houston (fig. 2). As the Trinity River flows south, it is impounded by Lake Livingston, about $50 \mathrm{mi}$ north of Lake Houston. Water-quality conditions upstream and downstream of Lake Livingston are considerably different, as suspended sediment and other water-borne constituents tend to settle out of suspension as velocity of the water slows as it passes through the reservoir. The Trinity River flows downstream from Lake Livingston and east of Lake Houston and, at its closest point to Lake Houston, is only about $3 \mathrm{mi}$ from the upstream end of Luce Bayou. Thus, Luce Bayou is a possible diversion point for the interbasin transfer of Trinity River water to Lake Houston.

\section{Water-Quality Data Available for 1983-90}

A total of 59 water-quality constituents and properties were sampled in Lake Houston, its tributaries, and the Trinity River during August 1983-September 1990. These data were used to define current hydrologic and water-quality conditions for the various water bodies. Nine of the available properties and constituents were used to calibrate and test the model and to simulate the various interbasin-transfer scenarios. Liscum and others (1999) provide a detailed characterization of the data.

The data-collection sites for Lake Houston and its tributaries (table 1) are grouped as: main body of the lake (transects A, B, C, and D), East Fork of the lake (transect E), West Fork of the lake (transect F), eastern tributaries (East Fork San Jacinto River, Caney Creek, Peach Creek, and Luce Bayou), and western tributaries (West Fork San Jacinto River, Spring Creek, and Cypress Creek) (fig. 2).

The lake sampling sites consist of the six transects (A-F) across the lake, each transect with a sampling site in the old river channel (center of transect) and a sampling site on either side of the center, between the old channel and the shoreline. Samples were collected at several points in the water column $(1 \mathrm{ft}$ beneath the surface, at selected intermediate depths, and $1 \mathrm{ft}$ above the bottom). Initially, samples were collected at the three sampling sites in each transect. However, statistical tests indicated no significant variance between the three sampling sites for constituents sampled at the same relative depth in the water column (Liscum and others, 1999). Beginning in May 1987, the center of transect sites were sampled more frequently than the two other sites on each transect. Only waterquality data were collected at the six transects. The volume of water stored in the reservoir and the amount of flow from the reservoir over the uncontrolled spillway were determined using USGS streamflow-gaging station 08072000 Lake Houston near Sheldon. Data describing public supply withdrawals from the lake just upstream of the spillway were obtained from the City of Houston.

The tributary sampling sites (fig. 2) are either existing or newly-established USGS streamflow-gaging stations. Stream-discharge and water-quality data were collected at the tributary sampling sites. Only six of the seven tributaries were sampled; Peach Creek was not sampled because it is hydrologically similar to nearby Caney Creek.

Trinity River water-quality samples were collected at station 08066500 Trinity River at Romayor (fig. 2, table 1), about $15 \mathrm{mi}$ upstream of a likely diversion point that would connect to Luce Bayou. Streamdischarge and water-quality data also were collected at this site.

Nine properties and constituents were required for the model to estimate selected water-quality changes-water temperature; total phosphorus; total ammonia nitrogen; total nitrite plus nitrate nitrogen; chlorophyll $a$; dissolved oxygen; total dissolved solids; total organic carbon (TOC); and dissolved iron (hereinafter referred to as iron). Water temperature and total dissolved solids affect water density and, thus, influence water movement throughout the reservoir. Total phosphorus, total ammonia nitrogen, and total nitrite plus nitrate nitrogen were the nutrients selected for this study. Chlorophyll $a$ is an indicator of the amount of algal biomass present. Chlorophyll $a$ was collected only at sampling sites in the euphotic zone (near the surface) of Lake Houston. Chlorophyll $a$ was greater during the summer at each site sampled (Liscum and others, 1999). Dissolved oxygen, which is essential for higher forms of life and controls many chemical reactions through oxidation, is an indicator of potential degradation of reservoir water quality. Dissolved oxygen concentrations indicate the general health of an aquatic system such as Lake Houston. TOC is a measure of the organic material that influences nutrient and algal biomass cycles in the reservoir; organic material for the model was defined as labile DOM, refractory DOM, 
Table 1. Surface-water-quality sampling sites in Lake Houston, Trinity River, and tributaries to Lake Houston

[mi ${ }^{2}$, square miles]

\begin{tabular}{|c|c|c|c|c|c|}
\hline $\begin{array}{l}\text { Station no. } \\
\text { or site } \\
\text { identification no. }\end{array}$ & Station or site name & $\begin{array}{l}\text { Drain- } \\
\text { age } \\
\text { area } \\
\left(\mathrm{mi}^{2}\right)\end{array}$ & $\begin{array}{l}\text { Lati- } \\
\text { tude }\end{array}$ & $\begin{array}{l}\text { Longi- } \\
\text { tude }\end{array}$ & Purpose \\
\hline \multicolumn{6}{|c|}{ Lake Houston sampling sites } \\
\hline 08072000 & Lake Houston near Sheldon, Tex. & 2,828 & $29^{\circ} 54^{\prime} 58^{\prime \prime}$ & $95^{\circ} 08^{\prime} 28^{\prime \prime}$ & $\begin{array}{l}\text { Define outflow from reservoir and volume } \\
\text { of water stored in Lake Houston }\end{array}$ \\
\hline 295516095080801 & Transect A, center at dam & -- & $29^{\circ} 55^{\prime} 16^{\prime \prime}$ & $95^{\circ} 08^{\prime} 08^{\prime \prime}$ & $\begin{array}{l}\text { Define water quality in main body of Lake } \\
\text { Houston }\end{array}$ \\
\hline 295702095091401 & Transect B, center & -- & $29^{\circ} 57^{\prime} 02^{\prime \prime}$ & $95^{\circ} 09^{\prime} 14^{\prime \prime}$ & $\begin{array}{l}\text { Define water quality in main body of Lake } \\
\text { Houston }\end{array}$ \\
\hline 295902095074201 & Transect $\mathrm{C}$, center & -- & $29^{\circ} 59^{\prime} 02^{\prime \prime}$ & $95^{\circ} 07^{\prime} 42^{\prime \prime}$ & $\begin{array}{l}\text { Define water quality in main body of Lake } \\
\text { Houston }\end{array}$ \\
\hline 300016095073401 & Transect $\mathrm{D}$, center & -- & $30^{\circ} 00^{\prime} 16^{\prime \prime}$ & $95^{\circ} 07^{\prime} 34^{\prime \prime}$ & $\begin{array}{l}\text { Define water quality in main body of Lake } \\
\text { Houston }\end{array}$ \\
\hline 300158095074601 & $\begin{array}{l}\text { Transect E, center at mouth of East } \\
\text { Fork to Lake Houston }\end{array}$ & -- & $30^{\circ} 01^{\prime} 58^{\prime \prime}$ & $95^{\circ} 07^{\prime} 46^{\prime \prime}$ & $\begin{array}{l}\text { Define water quality in East Fork of Lake } \\
\text { Houston }\end{array}$ \\
\hline 300209095091201 & $\begin{array}{l}\text { Transect F, center at mouth of West } \\
\text { Fork to Lake Houston }\end{array}$ & -- & $30^{\circ} 02^{\prime} 09^{\prime \prime}$ & $95^{\circ} 09^{\prime} 12^{\prime \prime}$ & $\begin{array}{l}\text { Define water quality in West Fork of Lake } \\
\text { Houston }\end{array}$ \\
\hline \multicolumn{6}{|c|}{ Trinity River and tributary sampling sites } \\
\hline 08066500 & Trinity River at Romayor, Tex. & 17,186 & $30^{\circ} 25^{\prime} 30^{\prime \prime}$ & $94^{\circ} 51^{\prime} 02^{\prime \prime}$ & $\begin{array}{l}\text { Define flow and water quality in Trinity } \\
\text { River }\end{array}$ \\
\hline 08068090 & $\begin{array}{l}\text { West Fork San Jacinto River above } \\
\text { Lake Houston near Porter, Tex. }\end{array}$ & 962 & $30^{\circ} 05^{\prime} 09^{\prime \prime}$ & $95^{\circ} 17^{\prime} 59^{\prime \prime}$ & $\begin{array}{l}\text { Define flow and water quality in West Fork } \\
\text { San Jacinto River }\end{array}$ \\
\hline 08068520 & Spring Creek at Spring, Tex. & 419 & $30^{\circ} 05^{\prime} 31^{\prime \prime}$ & $95^{\circ} 24^{\prime} 21^{\prime \prime}$ & $\begin{array}{l}\text { Define flow and water quality in Spring } \\
\text { Creek }\end{array}$ \\
\hline 08069000 & Cypress Creek near Westfield, Tex. & 285 & $30^{\circ} 02^{\prime} 08^{\prime \prime}$ & $95^{\circ} 25^{\prime} 43^{\prime \prime}$ & $\begin{array}{l}\text { Define flow and water quality in Cypress } \\
\text { Creek }\end{array}$ \\
\hline 08070200 & $\begin{array}{l}\text { East Fork San Jacinto River near } \\
\text { New Caney, Tex. }\end{array}$ & 388 & $30^{\circ} 08^{\prime} 43^{\prime \prime}$ & $95^{\circ} 07^{\prime} 27^{\prime \prime}$ & $\begin{array}{l}\text { Define flow and water quality in East Fork } \\
\text { San Jacinto River }\end{array}$ \\
\hline 08070500 & Caney Creek near Splendora, Tex. & 105 & $30^{\circ} 15^{\prime} 34^{\prime \prime}$ & $95^{\circ} 18^{\prime} 08^{\prime \prime}$ & $\begin{array}{l}\text { Define flow and water quality in Caney } \\
\text { Creek; estimate flow and water quality in } \\
\text { Peach Creek (08071000) }\end{array}$ \\
\hline 08071280 & $\begin{array}{l}\text { Luce Bayou above Lake Houston } \\
\text { near Huffman, Tex. }\end{array}$ & 218 & $30^{\circ} 06^{\prime} 34^{\prime \prime}$ & $95^{\circ} 03^{\prime} 35^{\prime \prime}$ & $\begin{array}{l}\text { Define flow and water quality in Luce } \\
\text { Bayou }\end{array}$ \\
\hline
\end{tabular}

and detritus, all determined from TOC. Iron affects nutrients through adsorption and settling.

Data collected August 1983-September 1990 indicated differences among the eastern and western tributaries and the Trinity River for eight of these properties and constituents (Liscum and others, 1999):

1. Total phosphorus, total ammonia nitrogen, total nitrite plus nitrate nitrogen, and total dissolved solids concentrations in the western tributaries generally were greater than in the eastern tributaries and were similar to concentrations in the Trinity River.

2. Water temperature and dissolved oxygen concentrations in the Trinity River generally were greater than in the eastern and western tributaries, which were similar.

3. Iron concentrations in the eastern tributaries were greater than in the western tributaries and 
Trinity River, and concentrations in the western tributaries were greater than in the Trinity River.

4. TOC concentrations, which were similar in the eastern and western tributaries, were slightly greater than concentrations in the Trinity River.

\section{Interbasin Water-Transfer Scenarios}

The objective of this study was to estimate the effects of transferring water into Lake Houston from a source outside the reservoir drainage basin that would provide additional water supply for the City of Houston. For this study, the Trinity River was selected as the source of interbasin transfer of water because it is the closest river basin of those considered (Trinity, Neches, and Sabine Rivers). A previous study (Turner, Collie, and Braden, Inc., 1972) also indicated the Trinity River as a potential source of water for transfer into Lake Houston.

To estimate the amount of water to be transferred into Lake Houston from the Trinity River, two assumptions were made regarding the need to supplement Lake Houston water. First, the continued population growth of Houston would require a larger supply of water than Lake Houston currently (1999) can provide. Second, if water from the San Jacinto River Basin that currently supplies Lake Houston was transferred to another basin (a possible result under a State water plan [Texas Water Development Board, 1990] to transfer water from the "water rich" areas of the State to those areas that are normally in need of water), additional water supply to Lake Houston would be needed to replace the water transferred out of the San Jacinto River Basin. These assumptions were used to develop six scenarios to transfer water from the Trinity River into Lake Houston.

The first three scenarios are related to East Fork streamflow and are based on the assumption that increased streamflow from the Trinity River would be transferred to the East Fork of the lake to satisfy increased demand for water supply. Streamflow is assumed to be transferred from the Trinity River unless any of the East Fork tributaries are in "flood." A "flood" is defined as flows greater than two times the annual mean discharge. The three scenarios are:

1. Trinity River streamflow equal to 50 percent of East Fork streamflow is transferred to stream- flow entering Lake Houston through the East Fork.

2. Trinity River streamflow equal to 100 percent of East Fork streamflow is added to streamflow entering Lake Houston through the East Fork.

3. Trinity River streamflow equal to 200 percent of East Fork streamflow is added to streamflow entering Lake Houston through the East Fork.

The last three scenarios are based on the assumption that streamflow from the West Fork San Jacinto River is being transferred to another basin in the State. Streamflow from the Trinity River is transferred to the East Fork (by way of Luce Bayou) so that the same amount of streamflow (as transferred from the West Fork San Jacinto River) enters Lake Houston. Streamflow is assumed to be transferred from the Trinity River unless any of the West Fork tributaries are in "flood." The three scenarios are:

4. Trinity River streamflow is used to replace 25 percent of West Fork streamflow, which has been transferred out of the basin.

5. Trinity River streamflow is used to replace 50 percent of West Fork streamflow, which has been transferred out of the basin.

6. Trinity River streamflow is used to replace 100 percent of West Fork streamflow, which has been transferred out of the basin.

Table 2 summarizes flow, including average annual import and export, for each of the six scenarios during 1985-90.

These scenarios were developed to represent a range of possible interbasin water transfers that could occur. The scenarios should provide estimates of the possible effects that such transfers might have on the water quality in Lake Houston.

\section{Acknowledgments}

The authors thank Jim Greenlee, Public Works Operations Manager, City of Houston, for helping to develop water-transfer scenarios involving transfer of streamflow from the Trinity River into Lake Houston. The authors also appreciate the comments and 
Table 2. Summary of flow for six water-transfer scenarios, 1985-90, Trinity River into Lake Houston

$\left[\mathrm{ft}^{3} / \mathrm{s}\right.$, cubic feet per second; --, not available]

\begin{tabular}{|c|c|c|c|c|c|}
\hline $\begin{array}{l}\text { Simulation } \\
\text { year }\end{array}$ & $\begin{array}{c}\text { Average annual Trinity } \\
\text { River flow imported } \\
\text { through East Fork } \\
\left(\mathrm{ft}^{3} / \mathrm{s}\right)\end{array}$ & $\begin{array}{l}\text { Average annual } \\
\text { flow in } \\
\text { East Fork } \\
\left(\mathrm{ft}^{3} / \mathbf{s}\right)\end{array}$ & $\begin{array}{c}\text { Average annual } \\
\text { flow in } \\
\text { West Fork } \\
\left(\mathrm{ft}^{3} / \mathrm{s}\right)\end{array}$ & $\begin{array}{l}\text { Average annual flow } \\
\text { exported from } \\
\text { West Fork } \\
\left(\mathrm{ft}^{3} / \mathrm{s}\right)\end{array}$ & $\begin{array}{c}\text { Average annual } \\
\text { water use, } \\
\text { Lake Houston } \\
\left(\mathrm{ft}^{3} / \mathrm{s}\right)\end{array}$ \\
\hline \multicolumn{6}{|c|}{ Scenario 1-Import Trinity River flow equal to 50 percent of East Fork flow } \\
\hline 1985 & 177 & 691 & 1,280 & 0 & 301 \\
\hline 1986 & 169 & 812 & 941 & 0 & 205 \\
\hline 1987 & 199 & 697 & 1,080 & 0 & 166 \\
\hline 1988 & 94.6 & 209 & 338 & 0 & 216 \\
\hline 1989 & 119 & 737 & 809 & 0 & 173 \\
\hline 1990 & 198 & 518 & 756 & 0 & 179 \\
\hline \multicolumn{6}{|c|}{ Scenario 2-Import Trinity River flow equal to 100 percent of East Fork flow } \\
\hline 1985 & 223 & 691 & 1,280 & 0 & 301 \\
\hline 1986 & 202 & 812 & 941 & 0 & 205 \\
\hline 1987 & 232 & 697 & 1,080 & 0 & 166 \\
\hline 1988 & 159 & 209 & 338 & 0 & 216 \\
\hline 1989 & 175 & 737 & 809 & 0 & 173 \\
\hline 1990 & 215 & 518 & 756 & 0 & 179 \\
\hline \multicolumn{6}{|c|}{ Scenario 3-Import Trinity River flow equal to 200 percent of East Fork flow } \\
\hline 1985 & 288 & 691 & 1,280 & 0 & 301 \\
\hline 1986 & 286 & 812 & 941 & 0 & 205 \\
\hline 1987 & 292 & 697 & 1,080 & 0 & 166 \\
\hline 1988 & 231 & 209 & 338 & 0 & 216 \\
\hline 1989 & 252 & 737 & 809 & 0 & 173 \\
\hline 1990 & 275 & 518 & 756 & 0 & 179 \\
\hline \multicolumn{6}{|c|}{$\begin{array}{l}\text { Scenario 4-Import Trinity River flow equal to } 25 \text { percent of West Fork flow, } \\
\text { which has been transferred out of basin }\end{array}$} \\
\hline 1985 & 243 & 691 & 1,280 & 576 & 301 \\
\hline 1986 & 202 & 812 & 941 & 435 & 205 \\
\hline 1987 & 209 & 697 & 1,080 & 468 & 166 \\
\hline 1988 & 84.4 & 209 & 338 & 165 & 216 \\
\hline 1989 & 126 & 737 & 809 & 355 & 173 \\
\hline 1990 & 178 & 518 & 756 & 344 & 179 \\
\hline \multicolumn{6}{|c|}{$\begin{array}{l}\text { Scenario 5-Import Trinity River flow equal to } 50 \text { percent of West Fork flow, } \\
\text { which has been transferred out of basin }\end{array}$} \\
\hline 1985 & 273 & 691 & 1,280 & 550 & 301 \\
\hline 1986 & 272 & 812 & 941 & 391 & 205 \\
\hline 1987 & 286 & 697 & 1,080 & 421 & 166 \\
\hline 1988 & 157 & 209 & 338 & 118 & 216 \\
\hline 1989 & 222 & 737 & 809 & 299 & 173 \\
\hline 1990 & 282 & 518 & 756 & 282 & 179 \\
\hline \multicolumn{6}{|c|}{$\begin{array}{l}\text { Scenario 6-Import Trinity River flow equal to } 100 \text { percent of West Fork flow, } \\
\text { which has been transferred out of basin }\end{array}$} \\
\hline 1985 & 389 & 691 & 1,280 & 493 & 301 \\
\hline 1986 & 341 & 812 & 941 & 363 & 205 \\
\hline 1987 & 347 & 697 & 1,080 & 389 & 166 \\
\hline 1988 & 287 & 209 & 338 & 32.8 & 216 \\
\hline 1989 & 286 & 737 & 809 & 271 & 173 \\
\hline 1990 & 299 & 518 & 756 & 280 & 179 \\
\hline
\end{tabular}


suggestions from the CE-QUAL-W2 model developer, T.M. Cole, U.S. Army Corps of Engineers, Vicksburg, Miss.

\section{APPLICATION OF CE-QUAL-W2 MODEL TO LAKE HOUSTON}

The introduction of transferred water into Lake Houston has the potential to substantially change or affect the water quality of the lake. Collection and analysis of hydrologic data alone do not provide a means to adequately assess possible future effects from interbasin transfer of water on the water quality of Lake Houston. A calibrated reservoir water-quality model, however, can be used to estimate these possible effects by simulating reservoir response to selected inflow scenarios.

Models are simplified representations of complex systems and allow the entire system to be visualized in a manner that otherwise might not be possible. The actual processes in nature cannot be described completely through mathematical formulas; therefore, models must be conceptual in nature. Additionally, models must be calibrated and tested using fieldcollected data. For this project, a large database was available to calibrate and test the model.

\section{Model Characteristics}

The U.S. Army Corps of Engineers water-quality model, CE-QUAL-W2, was chosen for this project. The model incorporates finite-difference techniques to approximate the solutions to the governing equations. The model "is a two-dimensional, longitudinal/vertical hydrodynamic and water-quality model" that is "best suited for relatively long and narrow water bodies exhibiting longitudinal and vertical water-quality gradients" (Cole and Buchak, 1995, p. 1). Additionally, the model accepts input from more than one inflow tributary, whereas many models accept input from only one inflow tributary. Lake Houston is a reservoir with seven major inflow tributaries and exhibits the longitudinal and vertical water-quality gradients recommended for the model.

CE-QUAL-W2 can be used to compute as many as 22 water-quality components. The model relies on a defined rectangular grid to describe the water body longitudinally and vertically. The water-quality components are modeled using either a conservative or nonconservative approach. For example, total dissolved solids are modeled conservatively; phosphorus, ammonia nitrogen, nitrite plus nitrate nitrogen, algal biomass, dissolved oxygen, labile DOM, refractory DOM, detritus, and iron are modeled using a nonconservative approach that includes tracking the internal flux between the target component and the other components (which are influences). The water-temperature dependence of the biological and chemical rates are controlled using a temperature-rate multiplier function. The controlling or limiting factor for biological activity (production and decline of algal biomass) is influenced predominantly by the interaction of three constituents or properties - the level of nitrogen in the lake, the level of phosphorus in the lake, or the amount of light energy available for photosynthesis in the lake. More detailed discussions regarding the theoretical basis and application of CE-QUAL-W2 are given by Cole and Buchak (1995).

Application of the model requires six types of data: (1) geometric data, (2) initial conditions, (3) boundary conditions, (4) coefficients and constants, (5) calibration data, and (6) simulation data.

Geometric data are used to define a rectangular grid for the finite-difference representation of the water body being modeled. These data, referred to as the bathymetry data, are composed of a sufficient number of typical cross sections to define the geometry of the water body. Bathymetry data define the longitudinal spacing between typical cross sections; the vertical spacing represents depth. A typical cross section is used to define a segment. A group of linearly linked segments define a branch for a water body. The vertical spacing is referred to as layer thickness. The computational grid for Lake Houston was defined as one branch with 31 active segments and 19 active layers (fig. 3). The model used a longitudinal spacing (DLX) of $1,000 \mathrm{~m}$, a layer thickness $(\mathrm{H})$ of $1.0 \mathrm{~m}$, and average cross-sectional widths defined using data interpreted from sonar surveys at multiple traverses on the reservoir. The most upstream active segment for the model, segment 2, is at the location of the West Fork San Jacinto River near Porter (08068090). Tributary inflow enters the computational grid at segment 7 for the remaining western tributaries, Spring Creek (08068520) and Cypress Creek (08069000), and at segment 17 for the eastern tributaries, East Fork San Jacinto River (08070200), Caney Creek (08070500), Peach Creek (08071000), and Luce Bayou (08071280). Segment 19 is located at transect E, just downstream from sampling transect F; and segment 32 is located 


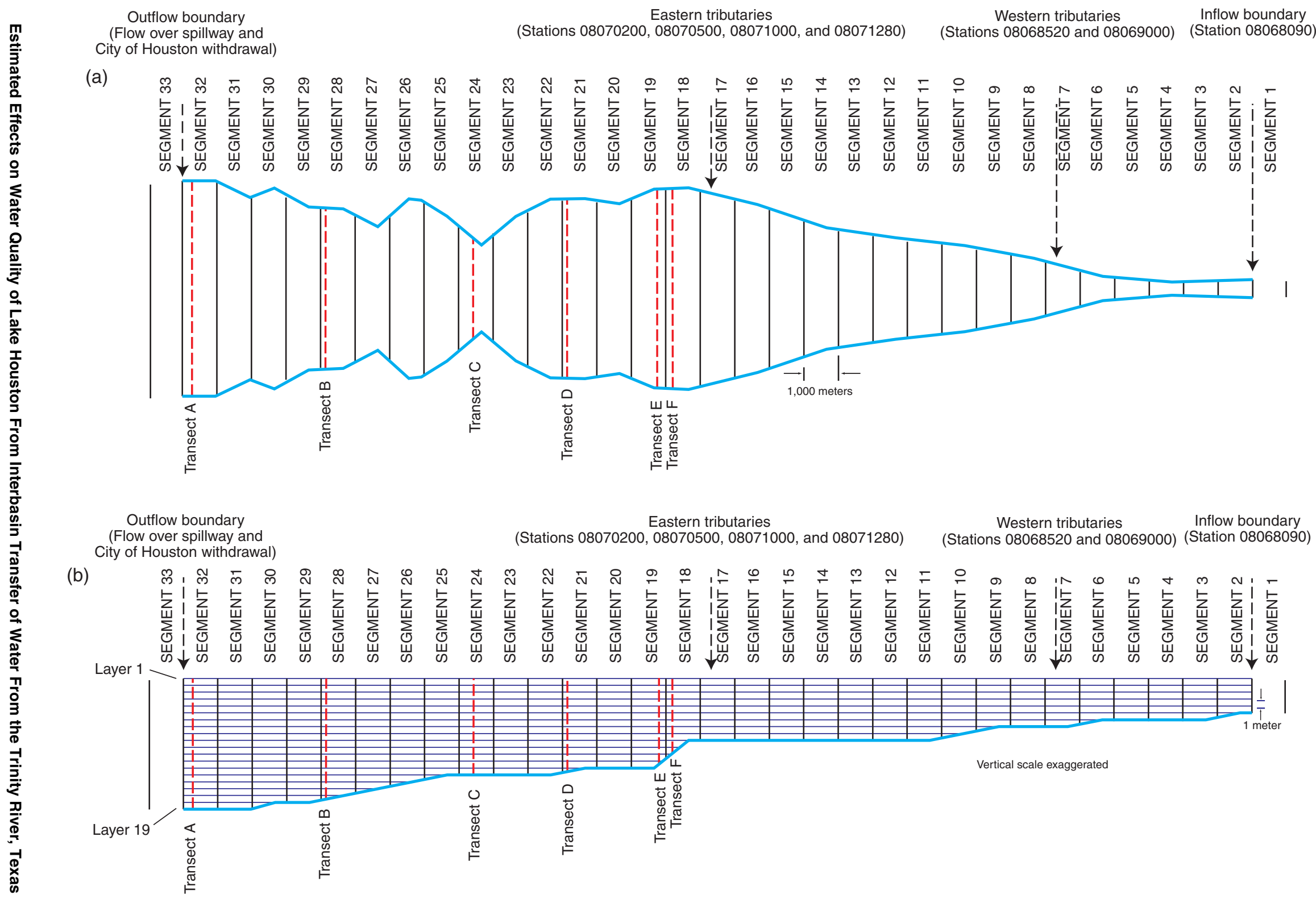

Figure 3. Schematic showing views of Lake Houston as represented in CE-QUAL-W2 model: (a) Plan view of surface layer; (b) Longitudinal cross-section view. 
near the dam, at the reservoir outflow and city withdrawal point (fig. 3).

Initial conditions set the beginning values for the water-surface elevation of the reservoir, water temperature throughout the reservoir, and concentrations of each water-quality constituent. Application of the model on Lake Houston was restricted to calendar year runs. Thus, initial values of the water-surface elevation, water temperature throughout the reservoir, and water-quality constituents were determined for January 1 of each year modeled (1985-90) from available observed data. The reservoir was assumed to be well mixed.

Boundary conditions set the limits for computing the various governing equations. The type and number of boundary conditions required were determined by the physiography of the water body being modeled. The required boundary conditions for Lake Houston were divided into three groups: inflows into the reservoir, outflows from the reservoir, and conditions between the water and the atmosphere at the boundary.

Lake Houston was modeled as one branch (fig. 3) with a single inflow (West Fork San Jacinto River) and six tributaries (Spring Creek, Cypress Creek, East Fork San Jacinto River, Caney Creek, Peach Creek, and Luce Bayou). The "one branch" configuration was adequate as depths were not sufficiently different in the two forks of the reservoir to require more branches; also, the use of "one branch" reduced computational time. The West Fork was chosen as the "branch" as opposed to the East Fork because the drainage area for the West Fork tributaries is about twice that of the East Fork tributaries. Observed data were used to define streamflow, water temperature, and concentrations of the waterquality constituents for the single inflow and for five of the six tributaries. Data for Peach Creek were estimated on the basis of the observed data for Caney Creek (08070500). Distributed tributary inflow was also used to define flow into the reservoir from areas (about 6 percent of the drainage basin) that were not gaged. The distributed tributary inflow was estimated as a prorated average of the inflow from the gaged basins (08068090, 08068520, 08069000, 08070200, 08070500, and 08071280).

Two outflows were defined for the reservoir. One was the flow over a nearly 3,200-ft-wide uncontrolled spillway, and the other was the flow withdrawn from Lake Houston for public supply. The outflow over the spillway was estimated on the basis of a stagedischarge relation that was accurate for flows greater than $2,500 \mathrm{ft}^{3} / \mathrm{s}$ and a mass balance of all flows into and out of the reservoir for flows less than $2,500 \mathrm{ft}^{3} / \mathrm{s}$ (when wind can affect flow over the wide spillway). The data describing public supply withdrawals from Lake Houston (just upstream of the spillway) were furnished by the City of Houston.

Knowledge of boundary conditions between the water and the atmosphere is required so that surface heat exchange, solar radiation absorption, wind stress, and gas exchange can be included in the model.

Detailed meteorologic data were available from the National Weather Service recording gage at Houston Intercontinental Airport (about $10 \mathrm{mi}$ west of Lake Houston). These data, which include hourly values of air and dew point temperatures, wind speed, wind direction, and cloud cover, were provided by the U.S. Army Corps of Engineers Waterways Experiment Station at Vicksburg, Miss.

For this study, CE-QUAL-W2 was used to compute 11 of the possible 22 water-quality componentswater temperature, phosphorus, ammonia nitrogen, nitrite plus nitrate nitrogen, algal biomass, dissolved oxygen, total dissolved solids, labile DOM, refractory DOM, detritus, and iron. Six of the water-quality components-water temperature, phosphorus, ammonia nitrogen, nitrite plus nitrate nitrogen, algal biomass, and dissolved oxygen - are also the targeted properties and constituents that are the main focus of this report. Five of the water-quality components-total dissolved solids, labile DOM, refractory DOM, detritus, and iron-are required by the model to compute the targeted properties and constituents. To compute the water temperature and water budget, the model requires 10 coefficients (table 3 ). A total of 42 coefficients affect constituent kinetics for the 10 remaining water-quality properties and constituents computed for the report (table 3). The values for the kinetic coefficients were determined during calibration, although Cole and Buchak (1995) provide guidelines and ranges to aid in the calibration process. In addition to the 42 kinetic coefficients, 8 other constants are defined; 7 of these define required stoichiometric equivalents and 1 defines the limiting value for dissolved oxygen concentrations, below which anaerobic processes begin. Table 3 presents all 60 coefficients and constants with their final values, typically the default values, which have been shown in applicable literature to provide the best model results. Cole and Buchak (1995) list default values and present a more complete discussion concerning recommendations for model coefficient selection. 
Table 3. Selected coefficients and constants determined for Lake Houston application of CE-QUAL-W2

[m, meter; sec, second; --, not applicable; W, watts; ${ }^{\circ} \mathrm{C}$, degrees Celsius; g, gram; SOD, sediment oxygen demand; DOM, dissolved organic matter]

\begin{tabular}{|c|c|c|c|}
\hline $\begin{array}{l}\text { Applicable model } \\
\text { component }\end{array}$ & Coefficient or constant & Value & Unit \\
\hline \multirow[t]{11}{*}{ Water temperature } & Longitudinal eddy viscosity & 1.0 & $\mathrm{~m}^{2}-\mathrm{sec}^{-1}$ \\
\hline & Longitudinal eddy diffusivity & 1.0 & $\mathrm{~m}^{2}-\sec ^{-1}$ \\
\hline & Chezy coefficient & 70.0 & $\mathrm{~m}^{0.5}-\mathrm{sec}^{-1}$ \\
\hline & Wind sheltering coefficient & 1.0 & -- \\
\hline & Fraction of incident solar radiation absorbed in the surface layer & .45 & -- \\
\hline & Coefficient of bottom heat exchange & $7.0^{-8}$ & $\mathrm{~W}-\mathrm{m}^{2}-\mathrm{sec}^{-1}$ \\
\hline & Bottom-sediment temperature & $20.4(1988)$ & ${ }^{\circ} \mathrm{C}$ \\
\hline & & $21.0(1989)$ & \\
\hline & Extinction coefficient for pure water & .45 & $\mathrm{~m}^{-1}$ \\
\hline & Extinction coefficient for inorganic solids & .01 & $m^{2}-g^{-1}$ \\
\hline & Extinction coefficient for organic solids & .40 & $m^{2}-g^{-1}$ \\
\hline \multirow[t]{3}{*}{ Phosphorus } & Sediment release rate of phosphorus as fraction of SOD & .005 & -- \\
\hline & Phosphorus partitioning coefficient for suspended solids & 1.2 & -- \\
\hline & Algal half-saturation constant for phosphorus & .003 & $\mathrm{~g}-\mathrm{m}^{-1}$ \\
\hline \multirow[t]{7}{*}{ Ammonia nitrogen } & Sediment release rate of ammonia as fraction of SOD & .005 & -- \\
\hline & Ammonia decay rate & .05 & day $^{-1}$ \\
\hline & Algal half-saturation constant for ammonia & .007 & $\mathrm{~g}-\mathrm{m}^{-1}$ \\
\hline & Lower temperature for ammonia decay & 5.0 & ${ }^{\circ} \mathrm{C}$ \\
\hline & Lower temperature for maximum ammonia decay & 25.0 & ${ }^{\circ} \mathrm{C}$ \\
\hline & Fraction of nitrification rate at lower temperature for ammonia decay & .1 & -- \\
\hline & Fraction of nitrification rate at lower temperature for maximum ammonia decay & .98 & -- \\
\hline \multirow{5}{*}{$\begin{array}{l}\text { Nitrite plus nitrate } \\
\text { nitrogen }\end{array}$} & Nitrate decay rate & 2.0 & day $^{-1}$ \\
\hline & Lower temperature for nitrate decay & 5.0 & ${ }^{\circ} \mathrm{C}$ \\
\hline & Lower temperature for maximum nitrate decay & 25.0 & ${ }^{\circ} \mathrm{C}$ \\
\hline & Fraction of denitrification rate at lower temperature for nitrate decay & .1 & -- \\
\hline & Fraction of denitrification rate at lower temperature for maximum nitrate decay & .98 & -- \\
\hline \multirow[t]{15}{*}{ Algal biomass } & Algal growth rate & 1.10 & day $^{-1}$ \\
\hline & Algal mortality rate & .01 & day $^{-1}$ \\
\hline & Algal excretion rate & .01 & day $^{-1}$ \\
\hline & Algal dark respiration rate & .045 & day $^{-1}$ \\
\hline & Algal settling rate & .01 & day $^{-1}$ \\
\hline & Saturation intensity at maximum photosynthetic rate & 100.0 & $\mathrm{~W}-\mathrm{m}^{2}$ \\
\hline & Fraction of algal biomass lost by mortality to detritus & .80 & -- \\
\hline & Lower temperature for algal growth & 10.0 & ${ }^{\circ} \mathrm{C}$ \\
\hline & Lower temperature for maximum algal growth & 30.0 & ${ }^{\circ} \mathrm{C}$ \\
\hline & Upper temperature for maximum algal growth & 35.0 & ${ }^{\circ} \mathrm{C}$ \\
\hline & Upper temperature for algal growth & 40.0 & ${ }^{\circ} \mathrm{C}$ \\
\hline & Fraction of algal growth rate at lower temperature for algal growth & .1 & -- \\
\hline & Fraction of maximum algal growth rate at lower temperature for maximum algal growth & .99 & -- \\
\hline & Fraction of maximum algal growth rate at upper temperature for maximum algal growth & .99 & -- \\
\hline & Fraction of algal growth rate at upper temperature for algal growth & .1 & -- \\
\hline
\end{tabular}


Table 3. Selected coefficients and constants determined for Lake Houston application of CE-QUAL-W2-Continued

\begin{tabular}{|c|c|c|c|}
\hline $\begin{array}{l}\text { Applicable model } \\
\text { component }\end{array}$ & Coefficient or constant & Value & Unit \\
\hline $\begin{array}{l}\text { Dissolved oxygen } \\
\text { and others (sedi- } \\
\text { ment, phospho- } \\
\text { rus, ammonia } \\
\text { nitrogen, carbon } \\
\text { dioxide, and iron) }\end{array}$ & Sediment oxygen demand & $\begin{array}{c}2.10 \\
\text { (segment 19) } \\
1.10 \\
\text { (segment 32) }\end{array}$ & g-m ${ }^{2}$ day $^{-1}$ \\
\hline Dissolved oxygen & Dissolved oxygen concentration at which anaerobic processes begin & .2 & $g-m^{-3}$ \\
\hline \multirow{3}{*}{$\begin{array}{l}\text { DOM, labile and } \\
\text { refractory }\end{array}$} & Labile DOM decay rate & .001 & day $^{-1}$ \\
\hline & Labile to refractory decay rate & .001 & day $^{-1}$ \\
\hline & Maximum refractory DOM decay rate & .0005 & day $^{-1}$ \\
\hline \multirow{6}{*}{$\begin{array}{l}\text { Particulate organic } \\
\text { matter (detritus) }\end{array}$} & Detritus decay rate & .001 & day $^{-1}$ \\
\hline & Detritus settling rate & .001 & day $^{-1}$ \\
\hline & Lower temperature for organic matter decay & 4.0 & ${ }^{\circ} \mathrm{C}$ \\
\hline & Lower temperature for maximum organic matter decay & 25.0 & ${ }^{\circ} \mathrm{C}$ \\
\hline & Fraction of organic matter decay at lower temperature for organic matter decay & .1 & -- \\
\hline & $\begin{array}{l}\text { Fraction of organic matter decay at lower temperature for maximum organic matter } \\
\text { decay }\end{array}$ & .98 & -- \\
\hline \multirow[t]{2}{*}{ Iron } & Iron sediment release rate as fraction of SOD & .30 & -- \\
\hline & Iron settling velocity & .50 & m-day ${ }^{-1}$ \\
\hline \multirow{7}{*}{$\begin{array}{l}\text { Algae, organic mat- } \\
\text { ter, phosphorus, } \\
\text { ammonia, nitrate, } \\
\text { and dissolved } \\
\text { oxygen }\end{array}$} & Oxygen stoichiometric equivalent for ammonia decay & 4.57 & -- \\
\hline & Oxygen stoichiometric equivalent for organic matter decay & 1.4 & -- \\
\hline & Oxygen stoichiometric equivalent for dark respiration & 1.4 & -- \\
\hline & Oxygen stoichiometric equivalent for algal growth & 1.4 & -- \\
\hline & Stoichiometric equivalent between organic matter and phosphorus & .011 & -- \\
\hline & Stoichiometric equivalent between organic matter and nitrogen & .08 & -- \\
\hline & Stoichiometric equivalent between organic matter and carbon & .45 & -- \\
\hline
\end{tabular}

Calibration data are crucial for any model application and, in this instance, consist of data to define the conditions in the water body at selected times as well as the contributions from inflows into the reservoir. Calibration data for Lake Houston were collected at six transects (fig. 2) in the reservoir during August 1983September 1990. Most of the data were collected at transect A, indicative of the water quality for the main body of Lake Houston and the public supply; transect E, representing the East Fork of the lake; and transect F, representing the West Fork of the lake. The greatest number of samples were collected during intensive sampling May 1987-September 1990 (Liscum and others, 1999). Water-quality data also were collected during these periods at the tributaries so that the contributions from the inflows could be defined.

Four constituents included in the model application could not be sampled directly-algal biomass, labile DOM, refractory DOM, and detritus. Chlorophyll $a$ (in milligrams per liter), measured during the study as an indicator for algal biomass, was used to define the algal biomass (in milligrams per liter) by the following relation (Cole and Buchak, 1995):

$$
\text { algal biomass }=67 * \text { chlorophyll } a .
$$

TOC (in milligrams per liter) was used to define DOM (labile and refractory) and particulate organic 
matter (detritus) (in milligrams per liter) by the following relations (Walter Rast, U.S. Geological Survey, written commun., 1991; Martin, 1987):

$$
\begin{gathered}
\text { labile DOM }=0.30 * \frac{(\mathrm{TOC})}{0.45}, \\
\text { refractory DOM }=\frac{0.70 *(\mathrm{TOC})}{0.45}, \text { and } \\
\text { detritus }=\frac{0.30 *(\mathrm{TOC})}{0.45} .
\end{gathered}
$$

The final type of data required for a model application is simulation data. To simulate water-quality conditions in Lake Houston, data characterizing inflow and outflow conditions are required. Inflow conditions are described using the six tributary sites, stations 08068090, 08068520, 08069000, 08070200, 08070500, and 08071280 (table 1). Outflow conditions are characterized by data from the reservoir site (station 08072000, table 1), and by data from the City of Houston detailing withdrawals from Lake Houston for public supply. Also, this application for Lake Houston required data representing water from the Trinity River. The Trinity River at Romayor (08066500) is the site closest to the probable withdrawal point (fig. 2). The data from this site are used to define the water quality of any flow withdrawn from the Trinity River and transferred to Lake Houston.

\section{Model Calibration and Testing}

Model calibration is an iterative process in which the user adjusts model coefficients until there is acceptable agreement between observed data and simulated results for the calibration period. Testing is a check of the calibrated model to determine if simulations are acceptable for a period different from that used for calibration. If the results of testing indicate poor agreement between observed and simulated data, the model is recalibrated and retested.

The Lake Houston CE-QUAL-W2 model was calibrated using observed flow and water-quality data for the 1988 calendar year; the model was tested using data for the 1989 calendar year. These periods were selected because more water-quality data were available for Lake Houston and the six tributaries for these 2 years than for other years. It is assumed that model calibration is more accurate and model testing is more representative using periods of the most observed data available. Streamflows for the 1988 calendar year are the smallest of any of the 6 years considered (1985-90), with a mean of $209 \mathrm{ft}^{3} / \mathrm{s}$ for the combined eastern tributaries and $338 \mathrm{ft}^{3} / \mathrm{s}$ for the combined western tributaries. Streamflows for the 1989 calendar year are larger, with a mean of $739 \mathrm{ft}^{3} / \mathrm{s}$ for the combined eastern tributaries and $809 \mathrm{ft}^{3} / \mathrm{s}$ for the combined western tributaries.

Calibration consisted of three steps. First, the model was checked to ensure that the observed water budget was reproduced by comparing observed and simulated water-surface elevations for the reservoir and by comparing associated computed volumes of water in the reservoir. Differences between observed and simulated water-surface elevations and differences between the associated computed reservoir volumes result from incorrect bathymetric data, incomplete or inaccurate flow data, poor simulation of evaporation, and seepage gains or losses. The bathymetric data were checked to within about 10 percent of the current capacity table throughout the range of water-surface elevations. All inflow and outflow water data were checked using simple mass-balance computations; when problems developed from using estimated flows, model inputs were adjusted to provide for mass balance. The effects of evaporation were accounted for by the original observed data; seepage gains or losses for Lake Houston were not substantial enough to affect calibration. Comparisons of the hydrographs of observed and simulated water-surface elevations for the calibration year (1988) and for the test year (1989) indicate that the shape of the hydrographs are reproduced very well. Differences between computed volumes of water in the reservoir for the observed and simulated water-surface elevations were less than 1 percent.

Second, the model was calibrated for simulation of water temperature. Water temperature is affected by surface and bottom heat exchange, as well as by hydrodynamics. Modeling water temperature is affected by mainstem and tributary inflows and their water temperature and location; outlet and withdrawal flows and their location; bathymetric data; and meteorologic variables. The model coefficients and constants that affect temperature (table 3 ) are longitudinal eddy viscosity; longitudinal eddy diffusivity; Chezy coefficient; wind-sheltering coefficient; fraction of incident solar radiation absorbed in the surface layer; coefficient of bottom heat exchange; bottom-sediment temperature; and extinction coefficient for light (consisting of a coefficient for pure water, for inorganic solids, and for 
organic solids). Cole and Buchak (1995, p. 26) state "applications on numerous reservoirs under a wide variety of conditions have shown that the model generates remarkable, accurate predictions using default values," and "the wind-sheltering coefficient has the most effect on temperature." This was the case for Lake Houston, where default values proved to be adequate for most of the previously mentioned coefficients and constants after the wind-sheltering coefficient was set to 1.00 (for open land) and the bottom-sediment temperature for each calendar year was set to the average yearly temperature for Lake Houston.

The third step of calibration was to determine the values of the kinetic coefficients needed to compute the 10 remaining water-quality constituents (phosphorus, ammonia nitrogen, nitrite plus nitrate nitrogen, algal biomass, dissolved oxygen, total dissolved solids, labile DOM, refractory DOM, detritus, and iron). This consisted of iterative runs using 1988 calendar year data, comparing plots of various simulated water-quality properties and constituents versus observed data for selected days, and comparing "goodness-of-fit" criteria among model runs using kinetic coefficients with different values. Testing was similar for 1989 calendar year data. The "goodness-of-fit" criteria were defined by the following evaluations:

1. Profile plots of the 11 properties and constituents on selected dates of data collection at the sampling transects in the lake were reviewed for visual comparison between observed and simulated data.

2. Volume-weighted concentration of each property and constituent at defined segments for each 1-hour increment during a model run were computed as:

$$
\mathrm{VWC}_{\mathrm{ji}}=\frac{\sum\left(\mathrm{C}_{\mathrm{j}}(\mathrm{k}, \mathrm{i}) * \operatorname{DLX}(\mathrm{i}) * \mathrm{BH}(\mathrm{k}, \mathrm{i})\right)}{\sum(\mathrm{DLX}(\mathrm{i}) * \mathrm{BH}(\mathrm{k}, \mathrm{i}))}
$$

where

$$
\begin{aligned}
& \text { VWC }=\text { volume-weighted concentration of } \\
& \text { constituent } j \text { at active segment } i \text {, } \\
& \mathrm{C}_{\mathrm{j}}(\mathrm{k}, \mathrm{i})=\text { concentration of constituent } \mathrm{j} \text { at layer } \mathrm{k} \text { in } \\
& \text { segment } i \text {, } \\
& \operatorname{DLX}(i)=\text { reach length for segment } i \text {, and } \\
& \mathrm{BH}(\mathrm{k}, \mathrm{i})=\text { product of the thickness of layer } \mathrm{k} \text { times } \\
& \text { the width of segment } i \text { at layer } k \text {. }
\end{aligned}
$$

From these data, the annual volume-weighted daily means were determined for observed and simulated data. A comparison of these values indicates how well the model performs for the annual time series.

3. The reliability index (RI), which compares the observed to the simulated data, was computed and used to evaluate how well the model performs (Leggett and Williams, 1981). The $\mathrm{RI}$ for a constituent is as follows:

$$
\mathrm{RI}=\frac{1+\sqrt{\frac{1}{\mathrm{~N}} \cdot \sum_{\mathrm{n}=1}^{\mathrm{N}}\left[\frac{1-\left(\mathrm{Y}_{\mathrm{o}}\right) /\left(\mathrm{Y}_{\mathrm{S}}\right)}{1+\left(\mathrm{Y}_{\mathrm{o}}\right) /\left(\mathrm{Y}_{\mathrm{s}}\right)}\right]^{2}}}{1-\sqrt{\frac{1}{\mathrm{~N}} \cdot \sum_{\mathrm{n}=1}^{\mathrm{N}}\left[\frac{1-\left(\mathrm{Y}_{\mathrm{o}}\right) /\left(\mathrm{Y}_{\mathrm{S}}\right)}{1+\left(\mathrm{Y}_{\mathrm{o}}\right) /\left(\mathrm{Y}_{\mathrm{s}}\right)}\right]^{2}}},
$$

where

$\mathrm{N}=$ all matching pairs of observed and simulated data, $\mathrm{Y}_{\mathrm{O}}=$ observed data, and $\mathrm{Y}_{\mathrm{s}}=$ simulated data.

An RI of 1.0 indicates perfect agreement between observed and simulated data; RI increases as observed and simulated data diverge. RI values do not depend on whether the observed or simulated value is greater. If all comparisons are on average one-half order of magnitude apart, RI would be 5.0 (Environmental Laboratory, 1986). Wlosinski (1984) considered $\mathrm{RI}$ to be the best statistic for aggregating model results using CE-QUAL-R1, the predecessor to CE-QUAL-W2. Martin (1987) also relied on RI to evaluate CE-QUAL-W2 in his study. RI values less than about 3.0 are considered to indicate an acceptable calibration. An RI greater than 10 might indicate extremely small values, usually for simulated data, which can mislead interpretation of results (Environmental Laboratory, 1986). RI values were used in this report to evaluate the final calibration and test run data.

The coefficients and constants required to calibrate CE-QUAL-W2 are summarized in table 3. The coefficients and constants determined for the Lake Houston model appear reasonable when compared to those determined by other users of this and similar models (Bowie and others, 1985; Cole and Buchak, 1995; Environmental Laboratory, 1986; Martin, 1987). The calibration and test run results were evaluated using the 
Table 4. Volume-weighted daily means computed for observed and simulated data for selected properties and constituents at segments 19 and 32 during calibration and test years

$\left[{ }^{\circ} \mathrm{C}\right.$, degrees Celsius; $\mathrm{mg} / \mathrm{L}$, milligrams per liter; DOM, dissolved organic matter]

\begin{tabular}{|c|c|c|c|c|c|c|c|c|}
\hline \multirow{3}{*}{$\begin{array}{l}\text { Property or constituent } \\
\quad \text { (unit of measure) }\end{array}$} & \multicolumn{4}{|c|}{1988 (model calibration year) } & \multicolumn{4}{|c|}{1989 (model test year) } \\
\hline & \multicolumn{2}{|c|}{ Segment 19} & \multicolumn{2}{|c|}{ Segment 32} & \multicolumn{2}{|c|}{ Segment 19} & \multicolumn{2}{|c|}{ Segment 32} \\
\hline & Observed & Simulated & Observed & Simulated & Observed & Simulated & Observed & Simulated \\
\hline Water temperature $\left({ }^{\circ} \mathrm{C}\right)$ & 27.1 & 27.3 & 25.8 & 25.6 & 23.6 & 24.2 & 23.0 & 23.4 \\
\hline Phosphorus (mg/L) & .18 & .93 & .14 & .72 & .16 & .62 & .18 & .57 \\
\hline Ammonia nitrogen $(\mathrm{mg} / \mathrm{L})$ & .03 & .04 & .02 & .04 & .05 & .05 & .05 & .05 \\
\hline Nitrite plus nitrate nitrogen $(\mathrm{mg} / \mathrm{L})$ & .10 & 1.04 & .13 & .85 & .10 & .76 & .14 & .60 \\
\hline Algal biomass (mg/L) & .50 & .18 & .19 & .16 & .20 & .04 & .07 & .06 \\
\hline Dissolved oxygen (mg/L) & 6.18 & 6.11 & 5.93 & 6.06 & 6.02 & 6.63 & 5.88 & 6.43 \\
\hline Total dissolved solids (mg/L) & 140.1 & 191.6 & 142.5 & 175.3 & 112.5 & 218.7 & 118.5 & 215.5 \\
\hline Labile DOM (mg/L) & 3.95 & 3.25 & 4.18 & 3.34 & 5.09 & 3.28 & 5.43 & 3.23 \\
\hline Refractory DOM (mg/L) & 9.21 & 8.60 & 9.77 & 9.18 & 11.87 & 8.16 & 12.68 & 8.17 \\
\hline Detritus (mg/L) & 5.64 & 4.85 & 5.97 & 5.07 & 7.27 & 4.79 & 7.76 & 4.75 \\
\hline Iron $(\mathrm{mg} / \mathrm{L})$ & .03 & .07 & .04 & .06 & .18 & .06 & .21 & .07 \\
\hline
\end{tabular}

"goodness-of-fit" criteria (previously stated) for two main parts of the reservoir (segment 19, transect E just downstream from transect $\mathrm{F}$; and segment 32, transect A near the dam-as shown in fig. 3).

Calibration and testing results are summarized by comparing observed and simulated data at segments 19 and 32 of Lake Houston on three selected dates for the calibration year (May 20, July 13, and September 6) and for the testing year (June 16, July 13, and September 7) (figs. 4a-v at end of report); by comparing observed and simulated volume-weighted daily means between calibration and testing years (table 4); and by assessing the RI for calibration and testing years (table 5). The results are summarized for both the targeted properties and constituents-water temperature, phosphorus, ammonia nitrogen, nitrite plus nitrate nitrogen, algal biomass, and dissolved oxygen - as well as those required by the model to compute the targeted properties and constituents-total dissolved solids, labile DOM, refractory DOM, detritus, and iron. Calibration and testing results are considered sufficiently accurate and reliable if they compare favorably to results from previous application. Calibration and testing results from Martin (1987) were compared to results from this study.

The model produced reliable results for water temperature and dissolved oxygen. In the authors' opinion, profile plots indicate very good correlation between observed and simulated data (figs. 4a-b, 4k-1). $\mathrm{RI}$ for model calibration and testing ranged from 1.04 to 1.15 for water temperature and from 1.17 to 1.23 for dissolved oxygen (table 5). The model also produced reliable results for ammonia nitrogen, total dissolved solids, labile and refractory DOM, and detritus. Profile plots indicate good correlation between observed and simulated data (figs. $4 \mathrm{e}-\mathrm{f}, 4 \mathrm{~m}-\mathrm{t}$ ). RI for model calibration and testing for the organic matter constituents ranged from a best (refractory DOM, 1.10 to 1.61) to a worst (ammonia nitrogen, 1.53 to 2.13). Observed and simulated phosphorus data are shown in figs. $4 \mathrm{c}-\mathrm{d}$. While vertical variation was simulated sufficiently, the model consistently overpredicted observed values at all sites. This overprediction was most likely caused by the fact that total phosphorus data were used as model input while CE-QUAL-W2 expects orthophosphorus. Orthophosphorus data were not collected from Lake Houston, therefore, total phosphorus was used as a surrogate. However, total phosphorus most probably settles in the reservoir but does not in the simulation, thus the overprediction. The objective of the model is not to make exact predictions of phosphorus concentrations but instead is to allow for comparison of the various water-transfer scenarios. As such, the use of total phosphorus still allows comparison of relative values, which meets the stated purpose. 
Table 5. Summary of reliability index computed for selected properties and constituents at segments 19 and 32 during calibration and test years

[DOM, dissolved organic matter]

\begin{tabular}{|c|c|c|c|c|}
\hline \multirow[t]{2}{*}{ Property or constituent } & \multicolumn{2}{|c|}{$\begin{array}{l}\text { Reliability index for } 1988 \\
\text { (model calibration year) }\end{array}$} & \multicolumn{2}{|c|}{$\begin{array}{l}\text { Reliability index for } 1989 \\
\text { (model test year) }\end{array}$} \\
\hline & Segment 19 & Segment 32 & Segment 19 & Segment 32 \\
\hline Water temperature & 1.05 & 1.04 & 1.15 & 1.11 \\
\hline Phosphorus & 4.42 & 4.42 & 3.92 & 3.18 \\
\hline Ammonia nitrogen & 2.13 & 2.08 & 1.53 & 1.57 \\
\hline Nitrite plus nitrate nitrogen & 9.78 & 7.27 & 6.55 & 4.44 \\
\hline Algal biomass & 4.14 & 3.08 & 33.10 & 31.95 \\
\hline Dissolved oxygen & 1.19 & 1.17 & 1.23 & 1.21 \\
\hline Total dissolved solids & 1.37 & 1.24 & 2.02 & 1.95 \\
\hline Labile DOM & 1.25 & 1.26 & 1.61 & 1.74 \\
\hline Refractory DOM & 1.16 & 1.10 & 1.53 & 1.61 \\
\hline Detritus & 1.21 & 1.19 & 1.57 & 1.68 \\
\hline Iron & 2.95 & 3.24 & 5.45 & 4.09 \\
\hline
\end{tabular}

RI values for model calibration and testing for nitrite plus nitrate nitrogen, algal biomass, and iron, which ranged from a best (iron, 2.95 to 5.45) to a worst (algal biomass, 3.08 to 33.10), indicate that model results might be inaccurate. As was the case for phosphorus, the objective of the model is not to make exact predictions of constituent concentrations but instead is to allow for comparison of the various water-transfer scenarios. As such, even though the model did not accurately predict nitrite plus nitrate nitrogen, algal biomass, and iron, relative comparison of simulated values for these constituents can still be made for various scenarios to assess potential effects of interbasin transfer.

This also is indicated by the profile plots for these constituents (figs. $4 \mathrm{~g}-\mathrm{j}, 4 \mathrm{u}-\mathrm{v}$ ). Improvements in the model calibration could be accomplished through improvements to various algorithms, as well as improvements to the calibration database. For instance, a more reliable computation of algal biomass and the inclusion of suspended sediment data for the inflows to Lake Houston and for the lake itself could improve the model components because of the interaction between either nutrients or iron and suspended sediments. However, RI values computed for these waterquality constituents are quite similar to those reported by Martin (1987). Therefore, it was determined that the
Lake Houston model was sufficiently calibrated within acceptable model tolerances.

\section{ESTIMATED EFFECTS OF INTERBASIN TRANSFER}

After calibrating and testing the model using observed data, model simulations were run for three categories of input data. These consisted of a base dataset and data for the two general water-transfer scenarios (augmenting East Fork tributary streamflow, replacing West Fork tributary streamflow) developed for this study. (See "Interbasin Water-Transfer Scenarios" section.) The base dataset was developed by a simulation using the observed data for January 1985-September 1990 at the tributary sites to Lake Houston and the model coefficients and constants determined in the calibration. The possible effects that interbasin transfers could have on the six targeted water-quality properties and constituents (water temperature, phosphorus, ammonia nitrogen, nitrite plus nitrate nitrogen, algal biomass, and dissolved oxygen) in Lake Houston were estimated by comparing the results of model simulations using the base dataset to the results of model simulations using the data for the two general watertransfer scenarios.

Model simulations using the model coefficients and constants determined during calibration (table 3) 
were made for each calendar year (or partial year) during January 1985-September 1990 for the base dataset and for each of the six water-transfer scenarios. Model results are illustrated by the volume-weighted daily mean concentrations simulated for each targeted property or constituent by day, selected calendar year, and entire simulation period. The selected calendar years were 1988, the low-flow year for the period, and 1985, the high-flow year for the period. Changes in the volume-weighted daily mean concentrations of the targeted properties and constituents for each of the six scenarios are shown for the low-flow and high-flow years (figs. 5a-f at end of report).

The estimated effects of the six water-transfer scenarios were evaluated on the basis of a compatibility index (CI) and a comparison of the means of the volume-weighted daily mean properties and constituents. The CI compares the simulated values of the properties and constituents for the base dataset to those for each water-transfer scenario in the same way that the RI compares observed and simulated data during calibration runs. The $\mathrm{CI}$ for this report is computed as:

$$
\mathrm{CI}=\frac{1+\sqrt{\frac{1}{\mathrm{~N}} \cdot \sum_{\mathrm{n}=1}^{\mathrm{N}}\left[\frac{1-\left(\mathrm{Y}_{\mathrm{s}}\right) /\left(\mathrm{Y}_{\mathrm{b}}\right)}{1+\left(\mathrm{Y}_{\mathrm{s}}\right) /\left(\mathrm{Y}_{\mathrm{b}}\right)}\right]^{2}}}{1-\sqrt{\frac{1}{\mathrm{~N}} \cdot \sum_{\mathrm{n}=1}^{\mathrm{N}}\left[\frac{1-\left(\mathrm{Y}_{\mathrm{s}}\right) /\left(\mathrm{Y}_{\mathrm{b}}\right)}{1+\left(\mathrm{Y}_{\mathrm{s}}\right) /\left(\mathrm{Y}_{\mathrm{b}}\right)}\right]^{2}}},
$$

where

$$
\mathrm{N}=\text { all matching pairs of simulated values for base }
$$
dataset and for a water-transfer scenario,

$\mathrm{Y}_{\mathrm{S}}=$ simulated value for water-transfer scenario, and

$\mathrm{Y}_{\mathrm{b}}=$ simulated value for base dataset.

A CI of 1.0 indicates no difference between base dataset results and water-transfer-scenario results. The $\mathrm{CI}$ increases as the difference increases.

The effects of the transfer of Trinity River water into Lake Houston were assumed to be of most consequence when considering the reservoir as a public supply. Furthermore, that part of Lake Houston nearest the City of Houston withdrawal point was considered critical. This section, nearest the spillway and including transect A (fig. 2), is segment 32 of the model (fig. 3). The following discussion of model results for the six water-transfer scenarios is limited to the values of the six targeted properties and constituents simulated for segment 32 .

The comparison between volume-weighted daily means simulated for the base dataset and for the water-transfer scenarios (figs. 5a-f) gave the following results:

\section{Low-flow year (1988)}

Water temperature - no appreciable difference Phosphorus - appreciable difference Ammonia nitrogen - minimal difference Nitrite plus nitrate nitrogen - appreciable difference Algal biomass - appreciable difference Dissolved oxygen - no appreciable difference

\section{High-flow year (1985)}

Water temperature - no appreciable difference Phosphorus - minimal difference Ammonia nitrogen - minimal difference Nitrite plus nitrate nitrogen - minimal difference Algal biomass - no appreciable difference Dissolved oxygen - no appreciable difference

The CI for water temperature indicated close agreement between simulations for the base dataset and each transfer scenario (table 6). The percent change between simulations for the base dataset and each transfer scenario was zero (table 7).

The CI confirmed that the differences between volume-weighted daily mean phosphorus, ammonia nitrogen, and nitrite plus nitrate nitrogen simulated for the base dataset and for the transfer scenarios increase as the percentage of transferred Trinity River water increases (table 6). As the percentage of transferred Trinity River water to augment East Fork tributary streamflow increased (scenarios 1-3), the volumeweighted daily means simulated for the nutrients generally stayed about the same or decreased slightly (figs. 5b-d); and as the percentage of transferred Trinity River water to replace West Fork tributary streamflow increased (scenarios 4-6), the volume-weighted daily means simulated generally decreased somewhat more than for the East Fork augmentation scenarios. However, the authors have less confidence in the results for phosphorus and nitrite plus nitrate nitrogen than for some of the other constituents because of problems encountered during calibration of these two nutrients. The percent change between simulations for the base dataset and for each of the water-transfer scenarios (table 7) indicated that replacing West Fork San Jacinto River streamflow with Trinity River water had a greater 
Table 6. Summary of compatibility index for volume-weighted daily mean properties and constituents simulated for base dataset and for six water-transfer scenarios at segment 32 in Lake Houston, during selected simulation periods

[DOM, dissolved organic material]

\begin{tabular}{|c|c|c|c|c|c|c|}
\hline \multirow[b]{2}{*}{ Property or constituent } & \multicolumn{6}{|c|}{ Compatibility index for simulation period, $1985-90$} \\
\hline & $\begin{array}{c}\text { Transfer } \\
\text { scenario } 1 \\
\text { (50 percent } \\
\text { of East } \\
\text { Fork flow) }\end{array}$ & $\begin{array}{c}\text { Transfer } \\
\text { scenario } 2 \\
\text { (100 percent } \\
\text { of East } \\
\text { Fork flow) }\end{array}$ & $\begin{array}{c}\text { Transfer } \\
\text { scenario } 3 \\
\text { (200 percent } \\
\text { of East } \\
\text { Fork flow) }\end{array}$ & $\begin{array}{c}\text { Transfer } \\
\text { scenario } 4 \\
\text { (25 percent } \\
\text { of West } \\
\text { Fork flow) }\end{array}$ & $\begin{array}{c}\text { Transfer } \\
\text { scenario } 5 \\
\text { (50 percent } \\
\text { of West } \\
\text { Fork flow) }\end{array}$ & $\begin{array}{c}\text { Transfer } \\
\text { scenario } 6 \\
\text { (100 percent } \\
\text { of West } \\
\text { Fork flow) }\end{array}$ \\
\hline Water temperature & 1.01 & 1.01 & 1.01 & 1.00 & 1.01 & 1.00 \\
\hline Phosphorus & 1.06 & 1.15 & 1.18 & 1.15 & 1.29 & 1.65 \\
\hline Ammonia nitrogen & 1.07 & 1.09 & 1.14 & 1.10 & 1.17 & 1.25 \\
\hline Nitrite plus nitrate nitrogen & 1.05 & 1.07 & 1.10 & 1.14 & 1.29 & 1.71 \\
\hline Algal biomass & 5.83 & 6.09 & 6.27 & 5.11 & 5.15 & 5.19 \\
\hline Dissolved oxygen & 1.02 & 1.03 & 1.04 & 1.01 & 1.01 & 1.02 \\
\hline
\end{tabular}

\begin{tabular}{lcccccc}
\hline & \multicolumn{7}{c}{ Compatibility index for low-flow year (1988) } \\
\cline { 2 - 7 } Property or constituent & $\begin{array}{c}\text { Transfer } \\
\text { scenario 1 } \\
\text { (50 percent } \\
\text { of East } \\
\text { Fork flow) }\end{array}$ & $\begin{array}{c}\text { Transfer } \\
\text { scenario 2 } \\
\text { (100 percent } \\
\text { of East } \\
\text { Fork flow) }\end{array}$ & $\begin{array}{c}\text { Transfer } \\
\text { scenario 3 } \\
\text { (200 percent } \\
\text { of East } \\
\text { Fork flow) }\end{array}$ & $\begin{array}{c}\text { Transfer } \\
\text { scenario 4 } \\
\text { (25 percent } \\
\text { of West } \\
\text { Fork flow) }\end{array}$ & $\begin{array}{c}\text { Transfer } \\
\text { scenario 5 } \\
\text { (50 percent } \\
\text { of West } \\
\text { Fork flow) }\end{array}$ & $\begin{array}{c}\text { Transfer } \\
\text { scenario 6 } \\
\text { (100 percent } \\
\text { of West } \\
\text { Fork flow) }\end{array}$ \\
\hline Water temperature & 1.01 & 1.01 & 1.01 & 1.00 & 1.00 & 1.01 \\
Phosphorus & 1.06 & 1.11 & 1.19 & 1.27 & 1.51 & 2.53 \\
Ammonia nitrogen & 1.10 & 1.16 & 1.19 & 1.09 & 1.16 & 1.31 \\
Nitrite plus nitrate nitrogen & 1.02 & 1.05 & 1.11 & 1.18 & 1.44 & 2.66 \\
Algal biomass & 1.48 & 1.85 & 1.98 & 1.17 & 1.31 & 1.64 \\
Dissolved oxygen & 1.02 & 1.02 & 1.02 & 1.01 & 1.01 & 1.02 \\
\hline
\end{tabular}

\begin{tabular}{lcccccc}
\hline \multirow{2}{*}{ Property or constituent } & \multicolumn{7}{c}{ Compatibility index for high-flow year (1985) } \\
\cline { 2 - 7 } & $\begin{array}{c}\text { Transfer } \\
\text { scenario 1 } \\
\text { (50 percent } \\
\text { of East } \\
\text { Fork flow) }\end{array}$ & $\begin{array}{c}\text { Transfer } \\
\text { scenario 2 } \\
\text { (100 percent } \\
\text { of East } \\
\text { Fork flow) }\end{array}$ & $\begin{array}{c}\text { Transfer } \\
\text { scenario 3 } \\
\text { (200 percent } \\
\text { of East } \\
\text { Fork flow) }\end{array}$ & $\begin{array}{c}\text { Transfer } \\
\text { scenario 4 } \\
\text { (25 percent } \\
\text { of West } \\
\text { Fork flow) }\end{array}$ & $\begin{array}{c}\text { Transfer } \\
\text { scenario 5 } \\
\text { (50 percent } \\
\text { of West } \\
\text { Fork flow) }\end{array}$ & $\begin{array}{c}\text { Transfer } \\
\text { scenario 6 } \\
\text { (100 percent } \\
\text { of West } \\
\text { Fork flow) }\end{array}$ \\
\hline Water temperature & 1.01 & 1.01 & 1.01 & 1.01 & 1.01 & 1.01 \\
Phosphorus & 1.12 & 1.05 & 1.05 & 1.04 & 1.07 & 1.12 \\
Ammonia nitrogen & 1.05 & 1.09 & 1.15 & 1.11 & 1.19 & 1.32 \\
Nitrite plus nitrate nitrogen & 1.11 & 1.12 & 1.14 & 1.14 & 1.19 & 1.33 \\
Algal biomass & 1.22 & 1.21 & 1.22 & 1.12 & 1.12 & 1.04 \\
Dissolved oxygen & 1.02 & 1.02 & 1.04 & 1.01 & 1.02 & 1.02 \\
\hline
\end{tabular}


Table 7. Summary of percent change between volume-weighted daily mean properties and constituents simulationed for base dataset and for six water-transfer scenarios at segment 32 in Lake Houston, 1985-90

$\left[{ }^{\circ} \mathrm{C}\right.$, degrees Celsius; $\mathrm{mg} / \mathrm{L}$, milligrams per liter; DOM, dissolved organic matter; $<$, less than]

\begin{tabular}{|c|c|c|c|c|c|c|c|}
\hline \multirow[b]{2}{*}{$\begin{array}{c}\text { Property or } \\
\text { constituent } \\
\text { (unit of measure) }\end{array}$} & \multirow{2}{*}{$\begin{array}{c}\text { Base } \\
\text { dataset } \\
\text { volume- } \\
\text { weighted } \\
\text { daily } \\
\text { mean }\end{array}$} & \multicolumn{3}{|c|}{$\begin{array}{l}\text { Percent change in volume-weighted } \\
\text { daily mean for water transfer to } \\
\text { augment East Fork flow }\end{array}$} & \multicolumn{3}{|c|}{$\begin{array}{l}\text { Percent change in volume- } \\
\text { weighted daily mean for water transfer } \\
\text { to replace West Fork flow }\end{array}$} \\
\hline & & $\begin{array}{l}\text { Transfer } \\
\text { scenario } 1 \\
\text { (50 per- } \\
\text { cent of } \\
\text { East } \\
\text { Fork flow) }\end{array}$ & $\begin{array}{l}\text { Transfer } \\
\text { scenario } 2 \\
\text { (100 per- } \\
\text { cent of } \\
\text { East } \\
\text { Fork flow) }\end{array}$ & $\begin{array}{l}\text { Transfer } \\
\text { scenario } 3 \\
\text { (200 per- } \\
\text { cent of } \\
\text { East } \\
\text { Fork flow) }\end{array}$ & $\begin{array}{c}\text { Transfer } \\
\text { scenario } 4 \\
\text { (25 per- } \\
\text { cent of } \\
\text { West } \\
\text { Fork flow) }\end{array}$ & $\begin{array}{c}\text { Transfer } \\
\text { scenario } 5 \\
\text { (50 per- } \\
\text { cent of } \\
\text { West } \\
\text { Fork flow) }\end{array}$ & $\begin{array}{l}\text { Transfer } \\
\text { scenario } 6 \\
\text { (100 per- } \\
\text { cent of } \\
\text { West } \\
\text { Fork flow) }\end{array}$ \\
\hline Water temperature $\left({ }^{\circ} \mathrm{C}\right)$ & 21.3 & 0 & 0 & 0 & 0 & 0 & 0 \\
\hline Phosphorus (mg/L) & .47 & -2 & -2 & -11 & -13 & -23 & -38 \\
\hline Ammonia nitrogen (mg/L) & .06 & 0 & 0 & 0 & 0 & 0 & -17 \\
\hline Nitrite plus nitrate nitrogen $(\mathrm{mg} / \mathrm{L})$ & .62 & 0 & 0 & -2 & -6 & -19 & -34 \\
\hline Algal biomass (mg/L) & .05 & -20 & -20 & -20 & +20 & +20 & +40 \\
\hline Dissolved oxygen (mg/L) & 6.77 & +1 & +1 & +2 & $<+1$ & $<+1$ & +1 \\
\hline
\end{tabular}

effect on nutrient concentrations than augmenting East Fork streamflow.

Simulation results indicated that transferring water from the Trinity River would have an effect on algal biomass; however, the problems calibrating algal biomass also might affect the accuracy of the simulation results. Except for the high-flow year, the CI indicated that the differences between the simulations for the base dataset and for each water-transfer scenario increased as the percentage of transferred Trinity River water increased (table 6). The percent change between simulations for the base dataset and for each of the water-transfer scenarios (table 7) indicated that as the percentage of transferred Trinity River water to augment East Fork streamflow increased (scenarios 1-3), algal biomass decreased; as the percentage of transferred Trinity River water to replace West Fork San Jacinto River streamflow increased (scenarios 4-6), algal biomass increased. Model results indicated that light was the limiting factor for algal biomass growth for each scenario simulated. These results are in agreement with Lee and Rast (1997) who concluded that primary production of algal biomass in Lake Houston is limited by light rather than by the nutrients, phosphorus and nitrogen.
The CI for dissolved oxygen indicated close agreement between simulated results for the base dataset and for each water-transfer scenario (table 6). The percent change between simulations for the base dataset and for each of the water-transfer scenarios (table 7) indicated that as the percentage of transferred Trinity River water to augment East Fork streamflow increased (scenarios 1-3), dissolved oxygen concentrations increased; as the percentage of transferred Trinity River water to replace West Fork streamflow increased (scenarios 4-6), dissolved oxygen concentrations increased.

The estimated effect on the water quality of Lake Houston from the transfer of Trinity River water to augment East Fork streamflow during the 1985-90 simulation period is as follows (table 7): Water temperature was not affected. The nutrients phosphorus and nitrite plus nitrate nitrogen decreased only slightly as the percentage of transferred Trinity River water increased-phosphorus by 2 to 11 percent, nitrite plus nitrate nitrogen by 0 to 2 percent; ammonia nitrogen did not change. Algal biomass decreased by 20 percent for all transfers of Trinity River water. Dissolved oxygen increased only slightly, by 1 to 2 percent, as the percentage of transferred Trinity River water increased.

The estimated effect on the water quality of Lake Houston from the transfer of Trinity River water to 
replace West Fork streamflow during the 1985-90 simulation period is as follows (table 7): Water temperature was not affected. Phosphorus and nitrite plus nitrate nitrogen decreased considerably as the percentage of transferred Trinity River water increased-phosphorus by 13 to 38 percent, nitrite plus nitrate nitrogen by 6 to 34 percent; ammonia nitrogen decreased by 0 to 17 percent. Algal biomass increased by 20 to 40 percent as the percentage of transferred Trinity River water increased. Dissolved oxygen increased about 1 percent for all transfers of Trinity River water.

The effects of transferring Trinity River water into Lake Houston, either to augment East Fork streamflow or to replace West Fork streamflow, do not appear to be detrimental to water temperature, ammonia nitrogen, or dissolved oxygen regardless of water-transfer scenario. Phosphorus and nitrite plus nitrate nitrogen showed fairly large changes if Trinity River water was transferred into Lake Houston to replace West Fork streamflow and minimal or no change if Trinity River water was transferred to augment East Fork streamflow. Algal biomass showed large decreases if Trinity River water was transferred into Lake Houston to augment East Fork streamflow and large increases if Trinity River water was transferred to replace West Fork streamflow. Regardless of the water-transfer scenario simulated, the model indicated that light was the limiting factor for algal biomass growth. It should be noted that improvements to this model application, including an improved algorithm for computing algal biomass and data for inflowing suspended sediments, might change the magnitude of some of the results, especially for phosphorus, nitrite plus nitrate nitrogen, and algal biomass. However, any changes between properties and constituents simulated for the various water-transfer scenarios should be consistent with results presented here because extensive experience with the model has shown that the model produces results consistent with the input data used.

\section{SUMMARY}

The City of Houston is considering the transfer of water from the Trinity River to Lake Houston on the San Jacinto River to alleviate concerns about adequate water supplies for future water demands. The U.S. Geological Survey, in cooperation with the City of Houston, conducted a study to estimate the effects on the water quality of Lake Houston from the transfer of Trinity River water. A water-quality model, CE-QUAL-W2, devel- oped by the U.S. Army Corps of Engineers was selected for the study.

Two general assumptions for water transfer were made. First, it was assumed that the continued population increase of Houston would require a larger supply of water than that currently (1999) available from Lake Houston. Second, it was assumed that if water that currently supplies Lake Houston were transferred to an area of the State in need of water, an additional water supply to Lake Houston would be needed. Six scenarios for water transfer from the Trinity River into Lake Houston were developed - three scenarios with Trinity River water augmenting streamflow from the East Fork of the lake and three scenarios with Trinity River water replacing streamflow from the West Fork of the San Jacinto River.

After calibrating and testing the model, model simulations were run for a base dataset (developed using observed data for January 1985-September 1990), the water-transfer scenarios augmenting East Fork streamflow, and the water-transfer scenarios replacing West Fork San Jacinto River streamflow. The model simulated volume-weighted daily means for six targeted properties and constituents-water temperature, phosphorus, ammonia nitrogen, nitrite plus nitrate nitrogen, algal biomass, and dissolved oxygen. Estimated effects were determined by comparing the results for each of the transfer scenarios to the results for the base dataset.

The estimated effect on the water quality of Lake Houston from the transfer of Trinity River water to augment East Fork streamflow during the 1985-90 simulation period is as follows: Water temperature and ammonia nitrogen were not affected. As the percentage of transferred Trinity River water increased, phosphorus and nitrite plus nitrate nitrogen decreased slightly and dissolved oxygen increased slightly. Algal biomass decreased by 20 percent for all transfers of Trinity River water.

The estimated effect on the water quality of Lake Houston from the transfer of Trinity River water to replace West Fork San Jacinto River streamflow during the 1985-90 simulation period is as follows: Water temperature was not affected; dissolved oxygen increased slightly. As the percentage of transferred Trinity River water increased, phosphorus decreased by 13 to 38 percent, ammonia nitrogen decreased by 0 to 17 percent, and nitrite plus nitrate nitrogen decreased by 6 to 34 percent. Algal biomass increased by 20 to 40 percent. 
The effects of transferring Trinity River water into Lake Houston, either to augment East Fork streamflow or to replace West Fork San Jacinto River streamflow, do not appear to be detrimental to water temperature, ammonia nitrogen, or dissolved oxygen regardless of water-transfer scenario. Phosphorus and nitrite plus nitrate nitrogen show fairly large changes when Trinity River water is transferred into Lake Houston to replace West Fork streamflow and minimal or no change when Trinity River water is transferred to augment East Fork streamflow. Algal biomass shows large decreases when Trinity River water is transferred into Lake Houston to augment East Fork streamflow and large increases when Trinity River water is transferred to replace West Fork streamflow. Regardless of the water-transfer scenario simulated, the model indicated that light was the limiting factor for algal biomass growth.

\section{SELECTED REFERENCES}

Baca, Ernesto, Bedient, P.B., and Olsen, R.J., 1982, Urban impacts of water supply reservoir: American Society of Civil Engineers, Journal of the Environmental Engineering Division, v. 108, no. 1, p. 73-87.

Bedient, P.B., Olsen, R.J., Baca, Ernesto, Newell, C.J., Lambert, J., Anderson, J., Rowe, P.G., and Ward, C.H., 1980, Environmental study of the Lake Houston watershed (phase I): Houston, City of Houston Department of Public Health Engineering; Rice University, Department of Environmental Science and Engineering.

Bowie, G.L., Mills, W.B., Porcella, D.B., Campbell, C.L., Pagenkopf, J.R., Rupp, G.L., Johnson, K.M., Chan, P.W.H., Gherini, S.A., and Chamberlin, C.E., 1985, Rates, constants, and kinetics formulations in surface water quality modeling ( $2 \mathrm{~d}$ ed.): Athens, Ga., U.S. Environmental Protection Agency, Environmental Research Laboratory, EPA/600/3-85/040, 455 p.

Cole, T.M., and Buchak, E.M., 1995, CE-QUAL-W2-A two-dimensional, laterally averaged, hydrodynamic and water-quality model, version 2.0: Vicksburg Miss., U.S. Army Corps of Engineers Waterways Experiment Station, Instruction Report EL-95-1, 57 p.

Environmental Laboratory, 1986, CE-QUAL-R1-A numerical one-dimensional model of reservoir water quality, user's manual (revised edition): Vicksburg,
Miss., U.S. Army Corps of Engineers Waterways Experiment Station, 400 p., 6 app.

Houston-Galveston Area Council, 1984, Nonpoint source pollution management in the Lake Houston watershed: Houston-Galveston Area Council, Community and Environmental Planning Department, $44 \mathrm{p}$.

Kingston, Mike, ed., 1991, Texas almanac 1992-1993: Dallas, The Dallas Morning News, $656 \mathrm{p}$.

Lee, R.W. and Rast, Walter, 1997, Light attenuation in a shallow, turbid reservoir, Lake Houston, Texas: U.S. Geological Survey Water-Resources Investigations Report 97-4064, 33 p.

Leggett, R.W., and Williams, L.R., 1981, A reliability index for models: Ecological Modeling, v. 13, p. 303-312.

Liscum, Fred, Goss, R.L., and Rast, Walter, 1999, Characteristics of water-quality data for Lake Houston, selected tributary inflows to Lake Houston, and the Trinity River (a potential source for interbasin transfer), August 1983-September 1990: U.S. Geological Survey Water-Resources Investigations Report 99-4129, $56 \mathrm{p}$.

Martin, J.L., 1987, Application of a two-dimensional model of hydrodynamics and water quality (CE-QUAL-W2) to Degray Lake, Arkansas: Vicksburg, Miss., U.S. Army Corps of Engineers Waterways Experiment Station, Technical Report E-87-1, 78 p., 1 app.

Matty, J.M., Anderson, J.B., and Dunbar, R.B., 1987, Suspended sediment transport, sedimentation, and resuspension in Lake Houston, Texas-Implications for water quality: Environmental Geology and Water Sciences, v. 10, no. 3, p.175-186.

Texas Water Development Board, 1990, Water for TexasToday and tomorrow: Texas Water Development Board, Document GP-5-1, $170 \mathrm{p}$.

Turner, Collie, and Braden, Inc., 1972, A comprehensive study of Houston's municipal water system, phase III, distribution system and overall cost scheduling: Consulting engineers' report, $14 \mathrm{p}$.

U.S. Geological Survey, 1984-91, Water resources data, Texas, water years 1983-90, v. 1-2: U.S. Geological Survey Water-Data Report, TX-83-1 to TX-90-1, and TX-83-2 to TX-90-2.

Wlosinski, J.H., 1984, Evaluation techniques for CE-QUAL-R1-A one-dimensional reservoir water quality model: Vicksburg, Miss., U.S. Army Corps of Engineers Waterways Experiment Station, Miscellaneous Paper E-84-1, 29 p. 
Segment 19

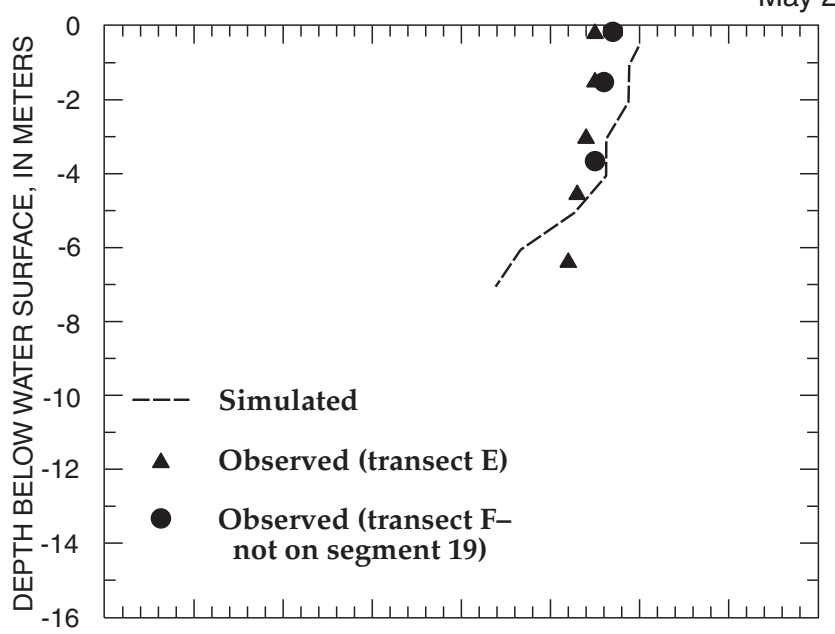

July 13,1988
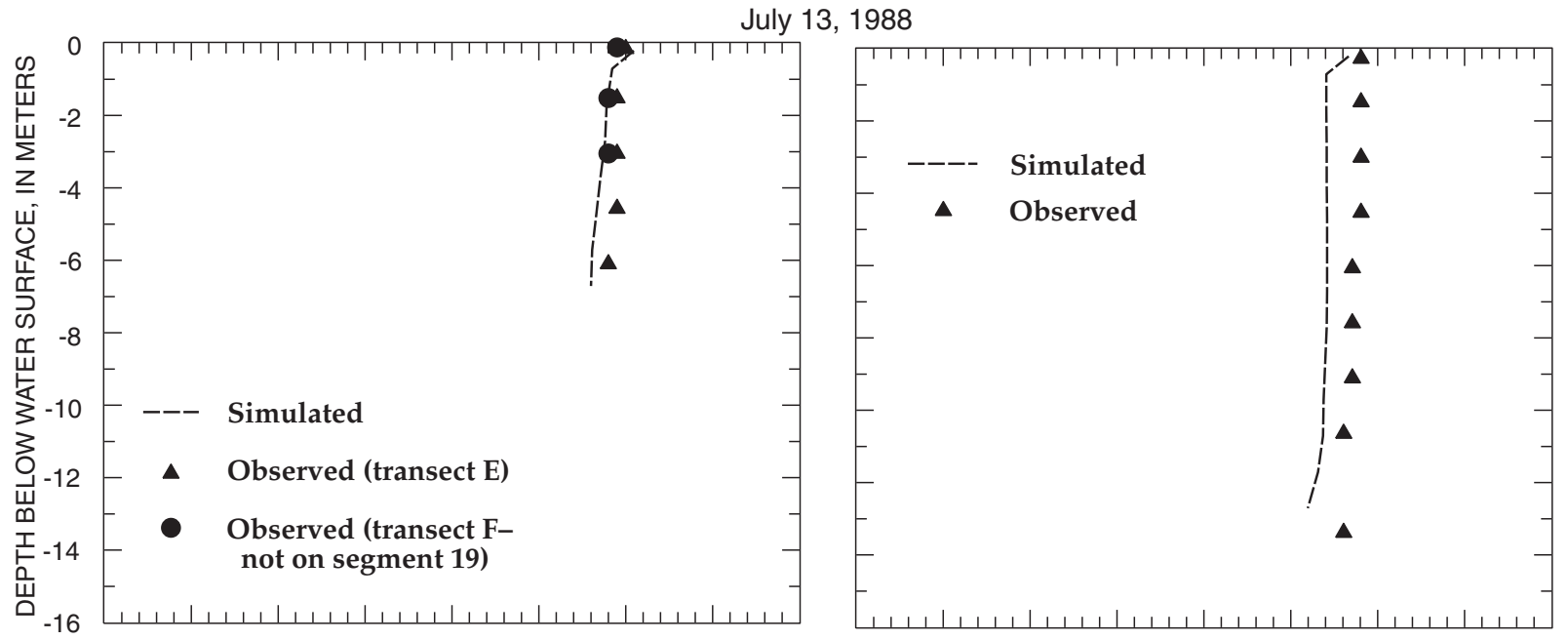

September 6, 1988
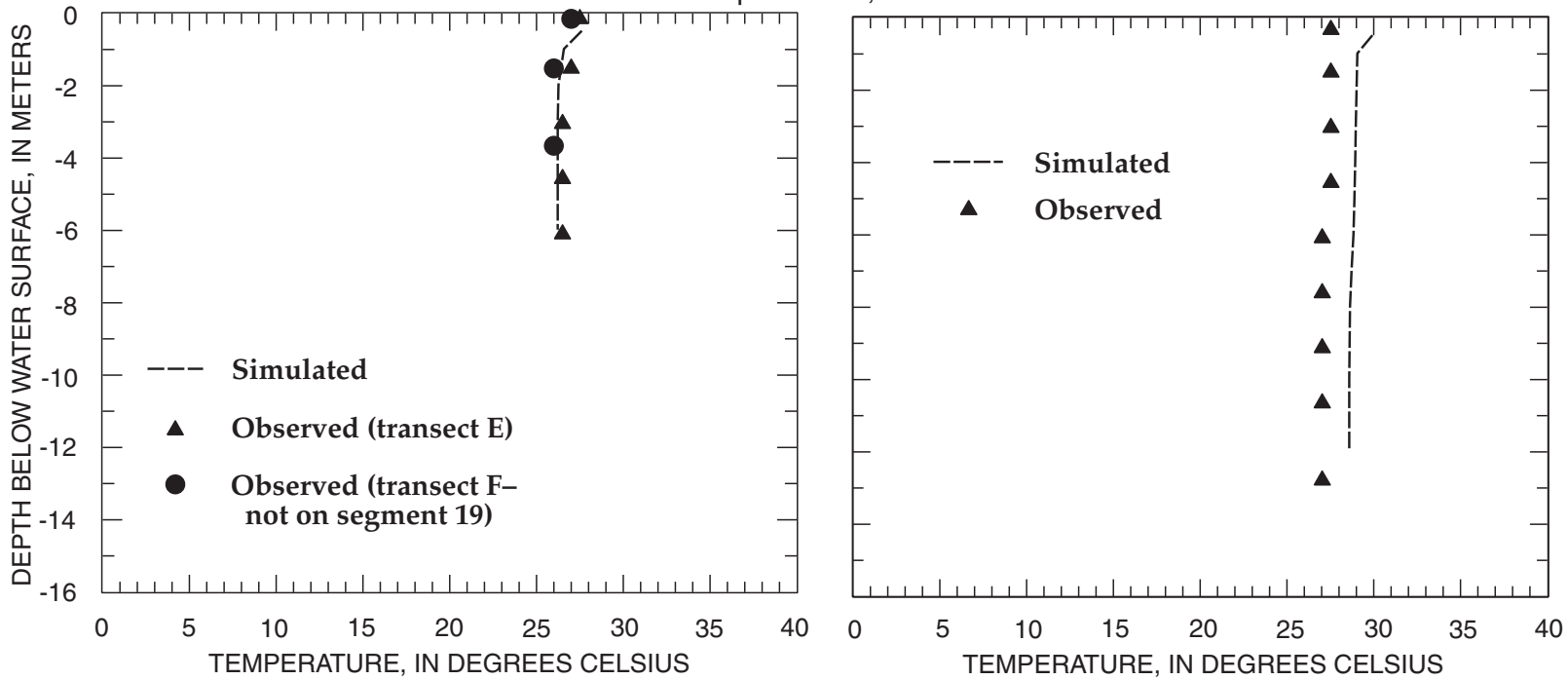

Figure 4a. Water temperature as computed during model calibration at segments 19 and 32 in Lake Houston for selected dates. 
Segment 19

June 16, 1989

Segment 32
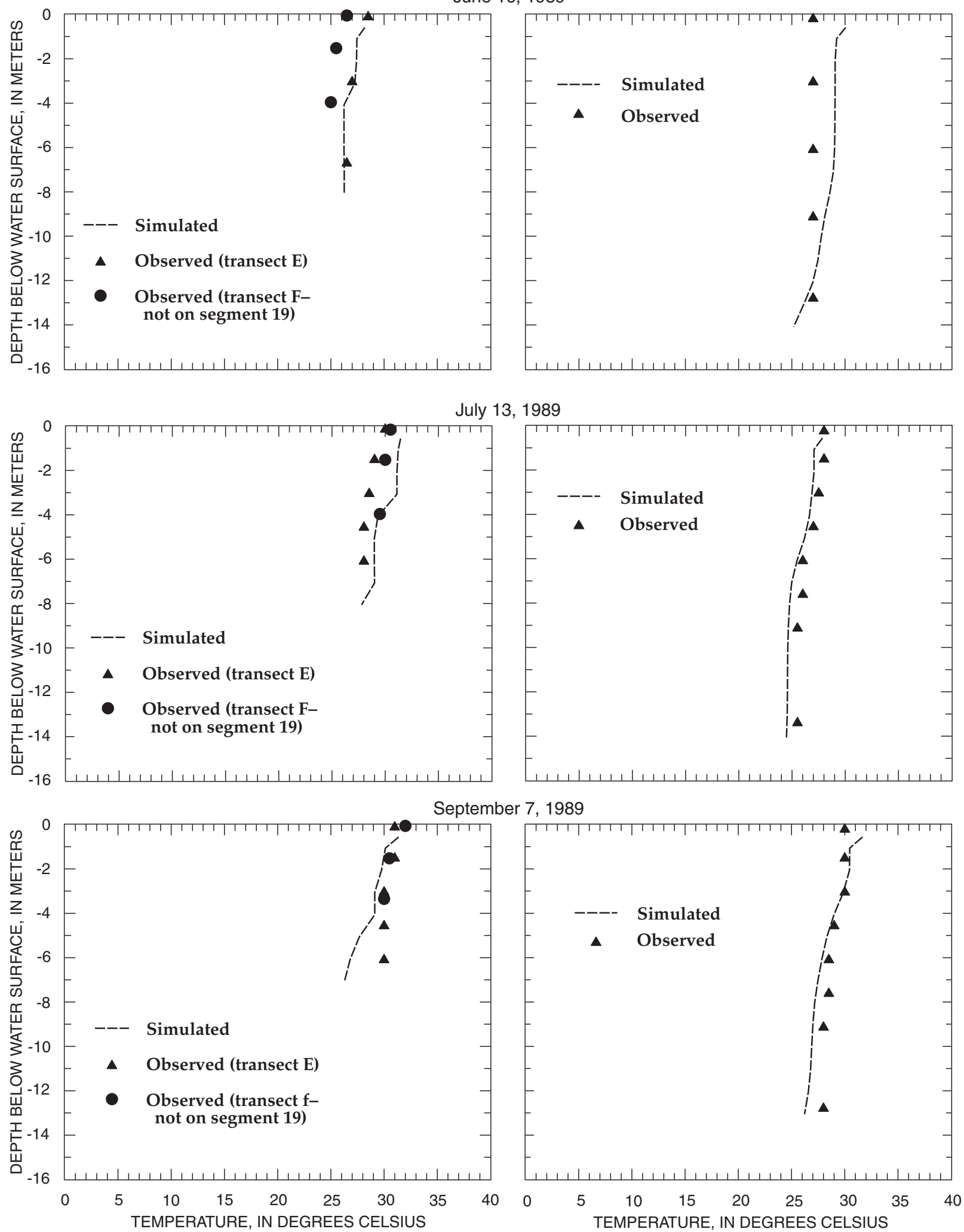

Figure 4b. Water temperature as computed during model test run at segments 19 and 32 in Lake Houston for selected dates. 

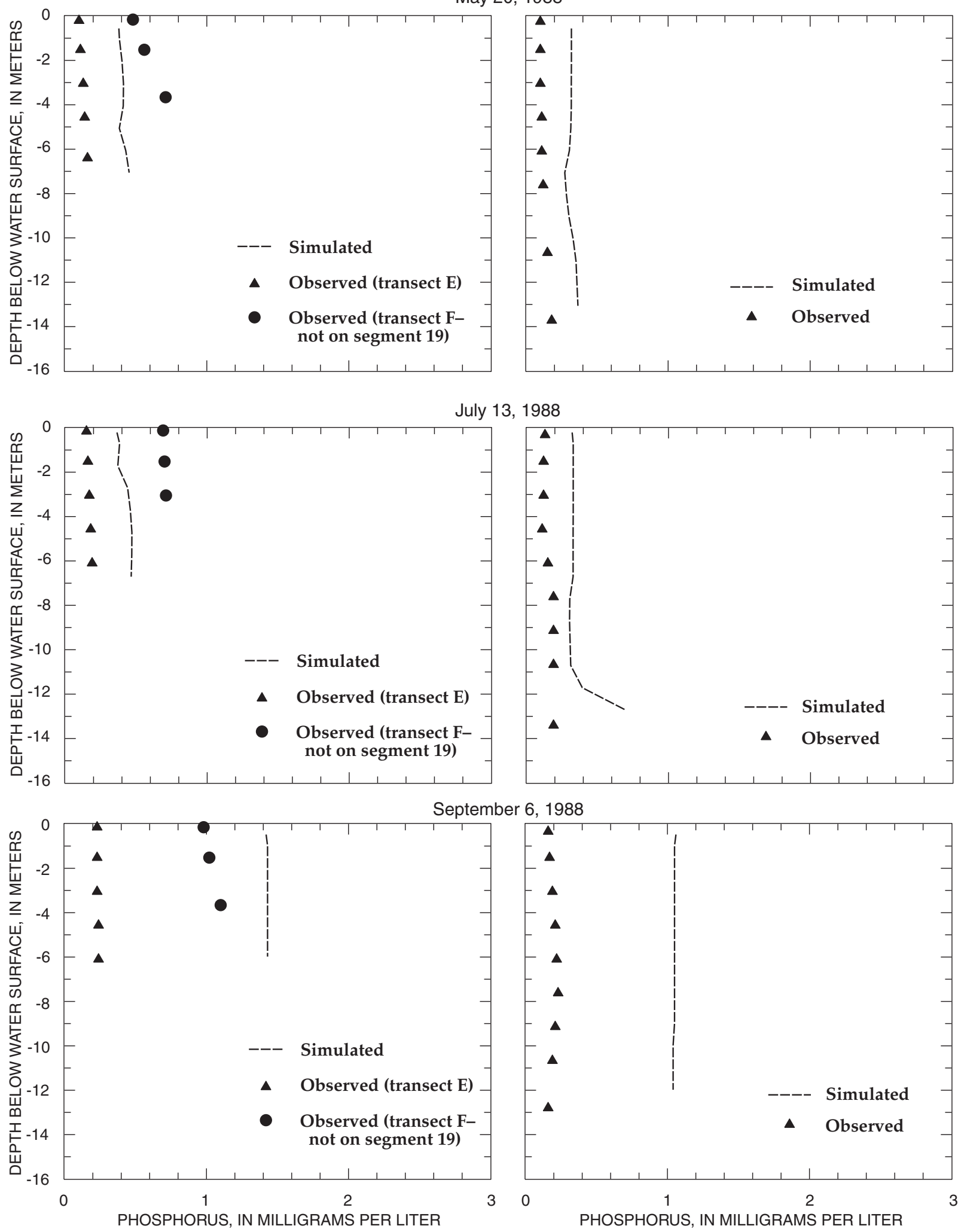

Figure 4c. Phosphorus as computed during model calibration at segments 19 and 32 in Lake Houston for selected dates. 

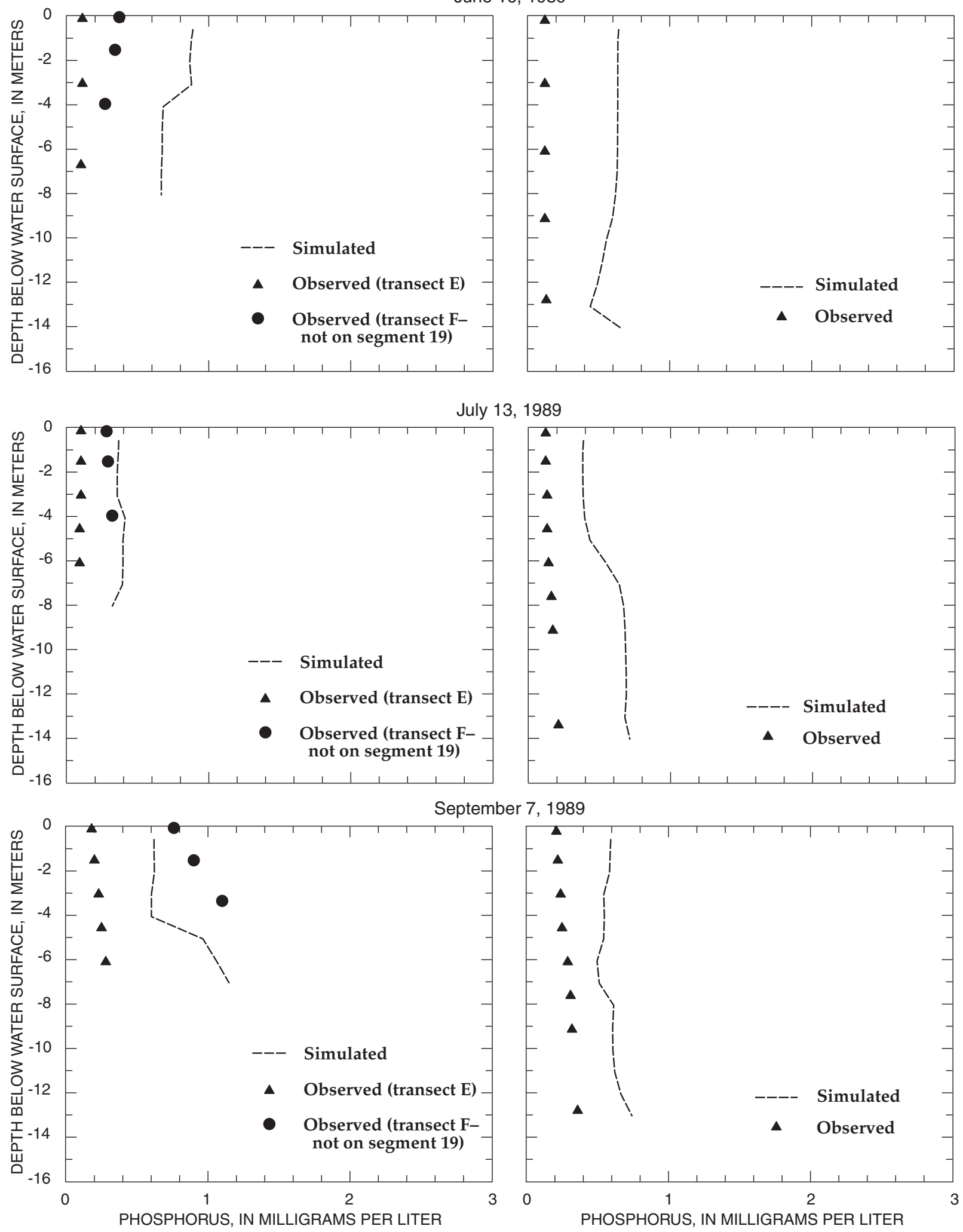

Figure 4d. Phosphorus as computed during model test run at segments 19 and 32 in Lake Houston for selected dates. 

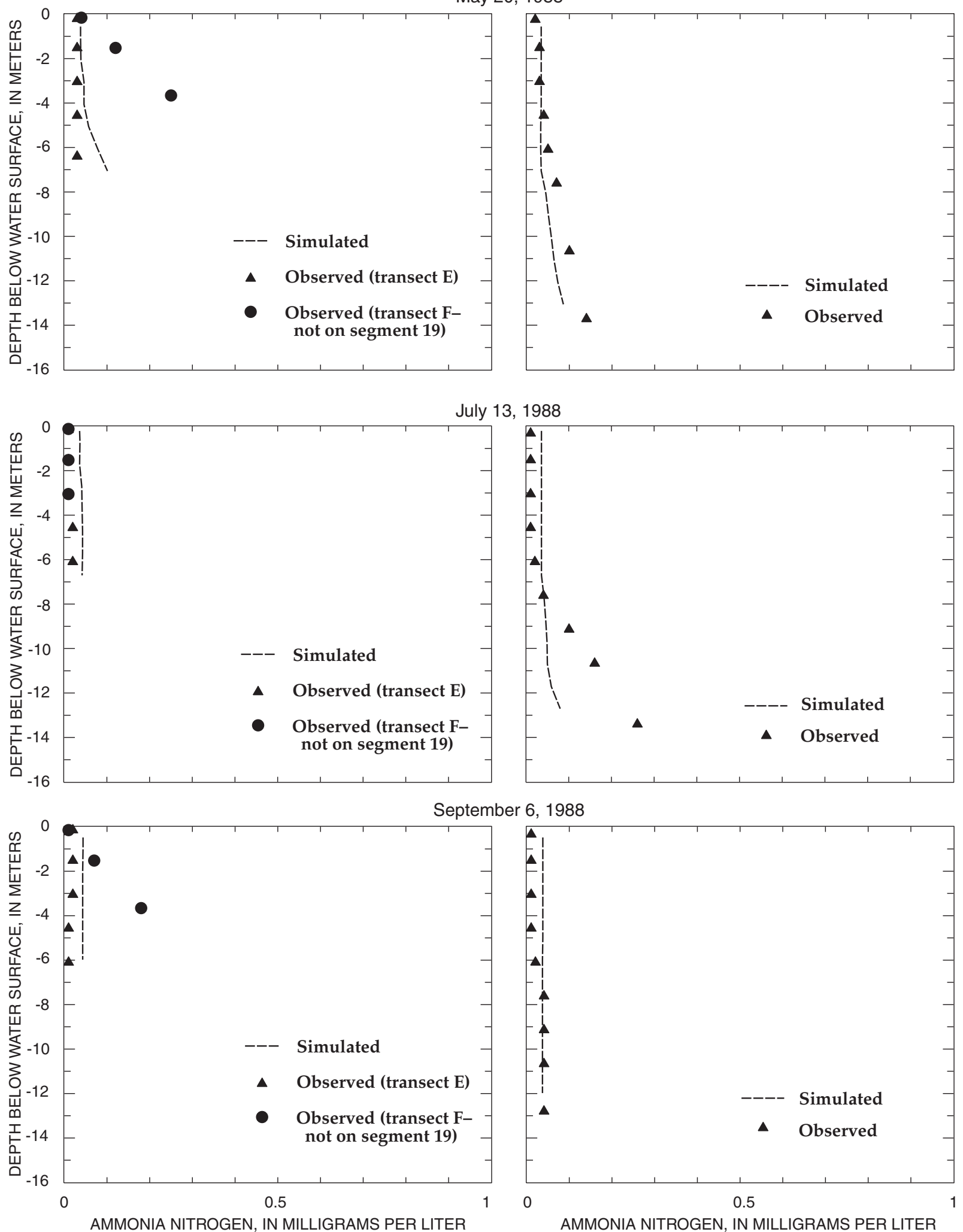

Figure 4e. Ammonia nitrogen as computed during model calibration at segments 19 and 32 in Lake Houston for selected dates. 


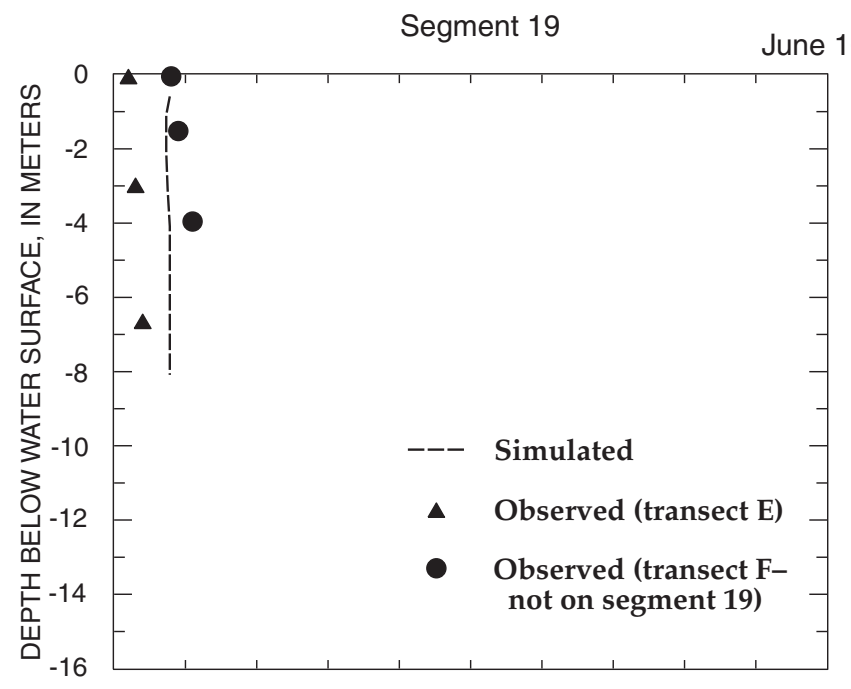

Segment 32
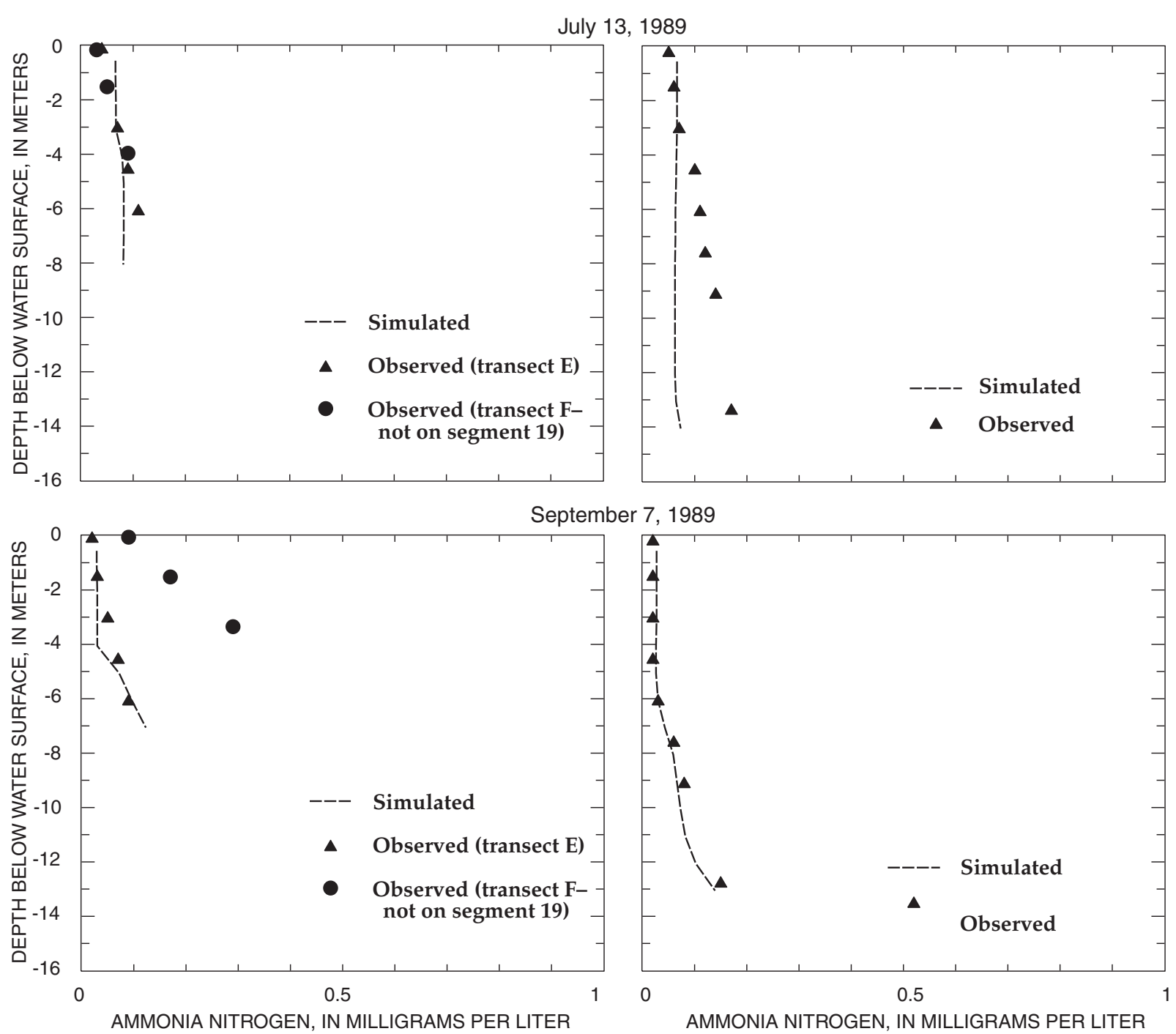

Figure 4f. Ammonia nitrogen as computed during model test run at segments 19 and 32 in Lake Houston for selected dates. 


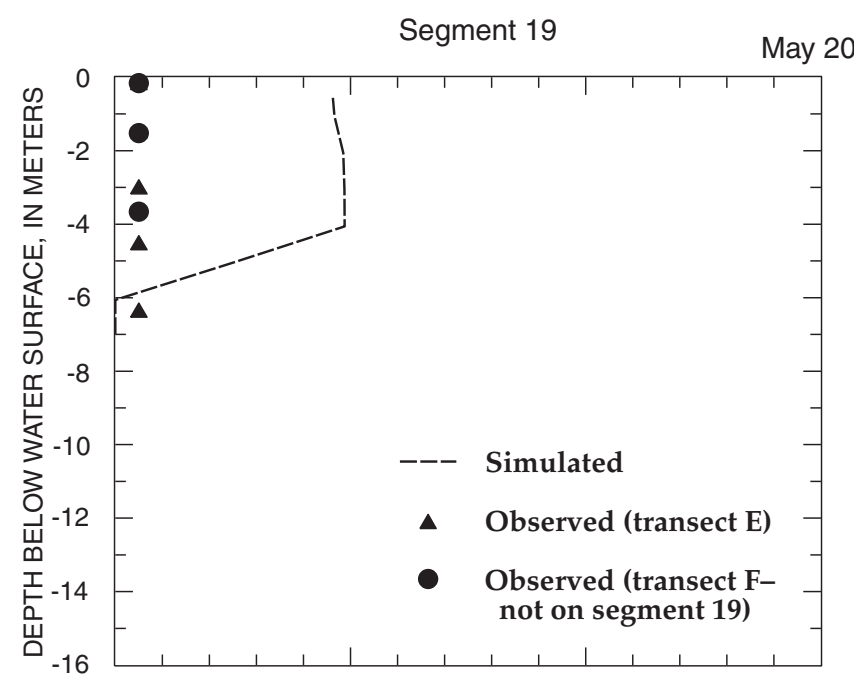

Segment 32
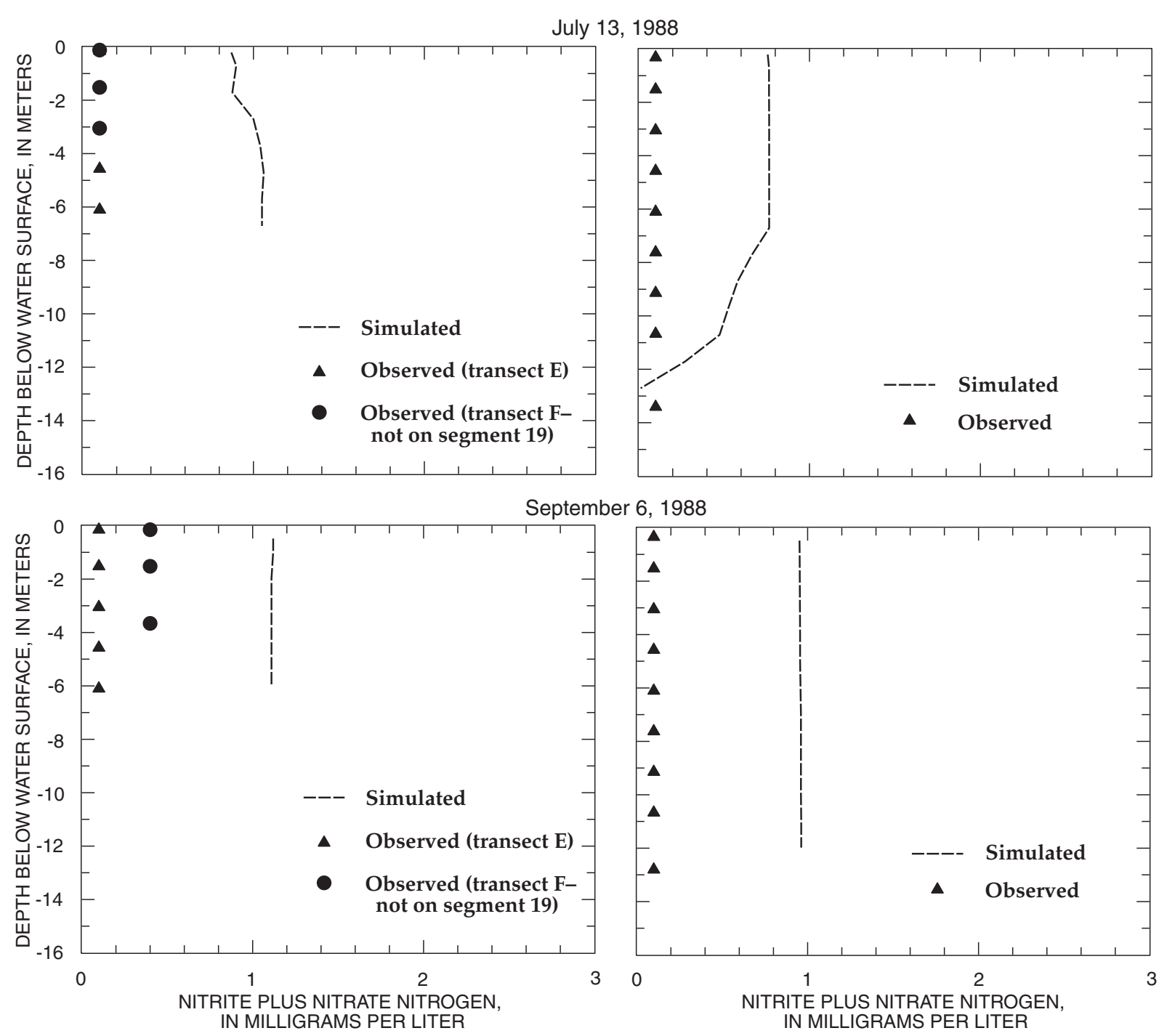

Figure 4g. Nitrite plus nitrate nitrogen as computed during model calibration at segments 19 and 32 in Lake Houston for selected dates. 

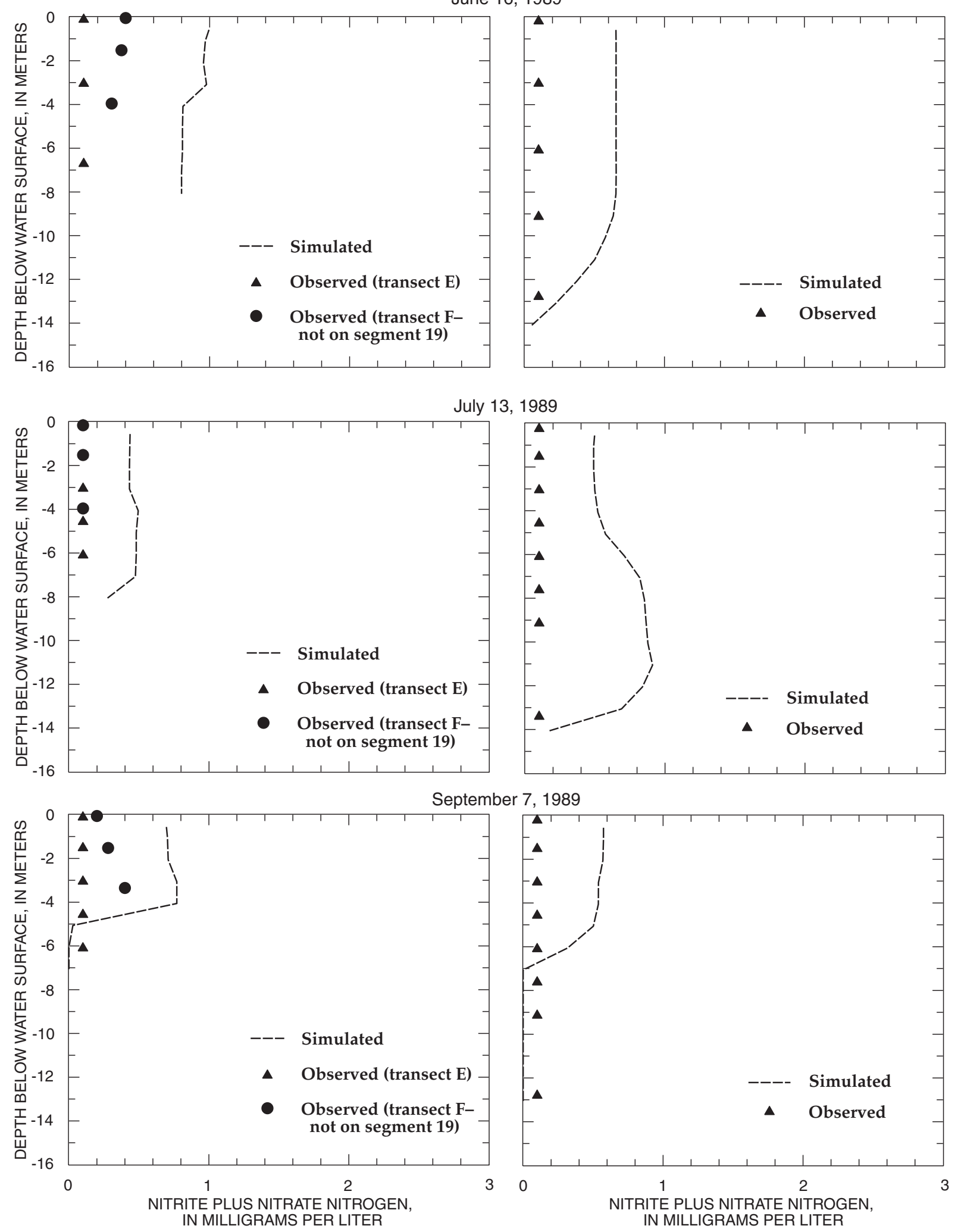

Figure 4h. Nitrite plus nitrate nitrogen as computed during model test run at segments 19 and 32 in Lake Houston for selected dates. 

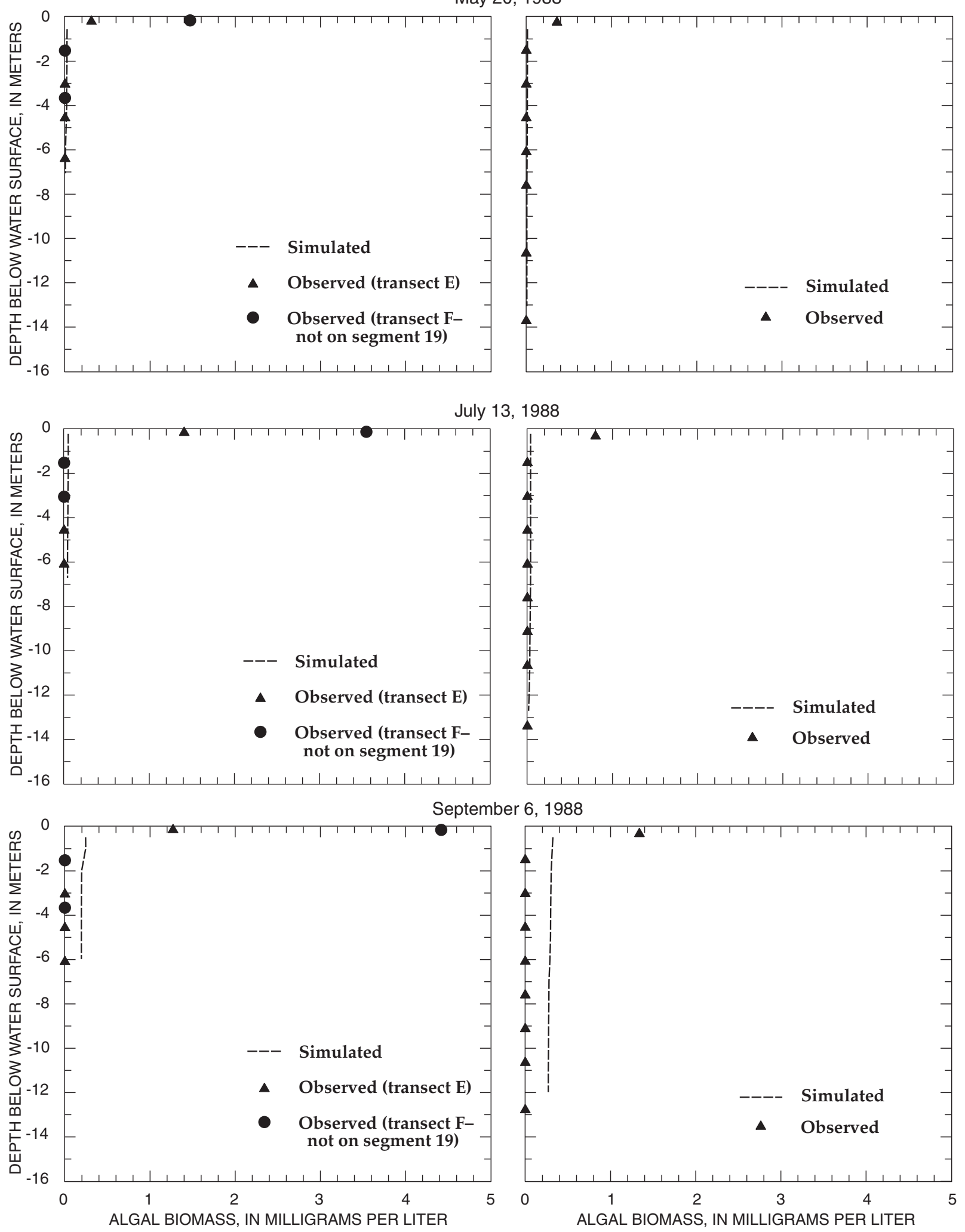

Figure 4i. Algal biomass as computed during model calibration at segments 19 and 32 in Lake Houston for selected dates. 

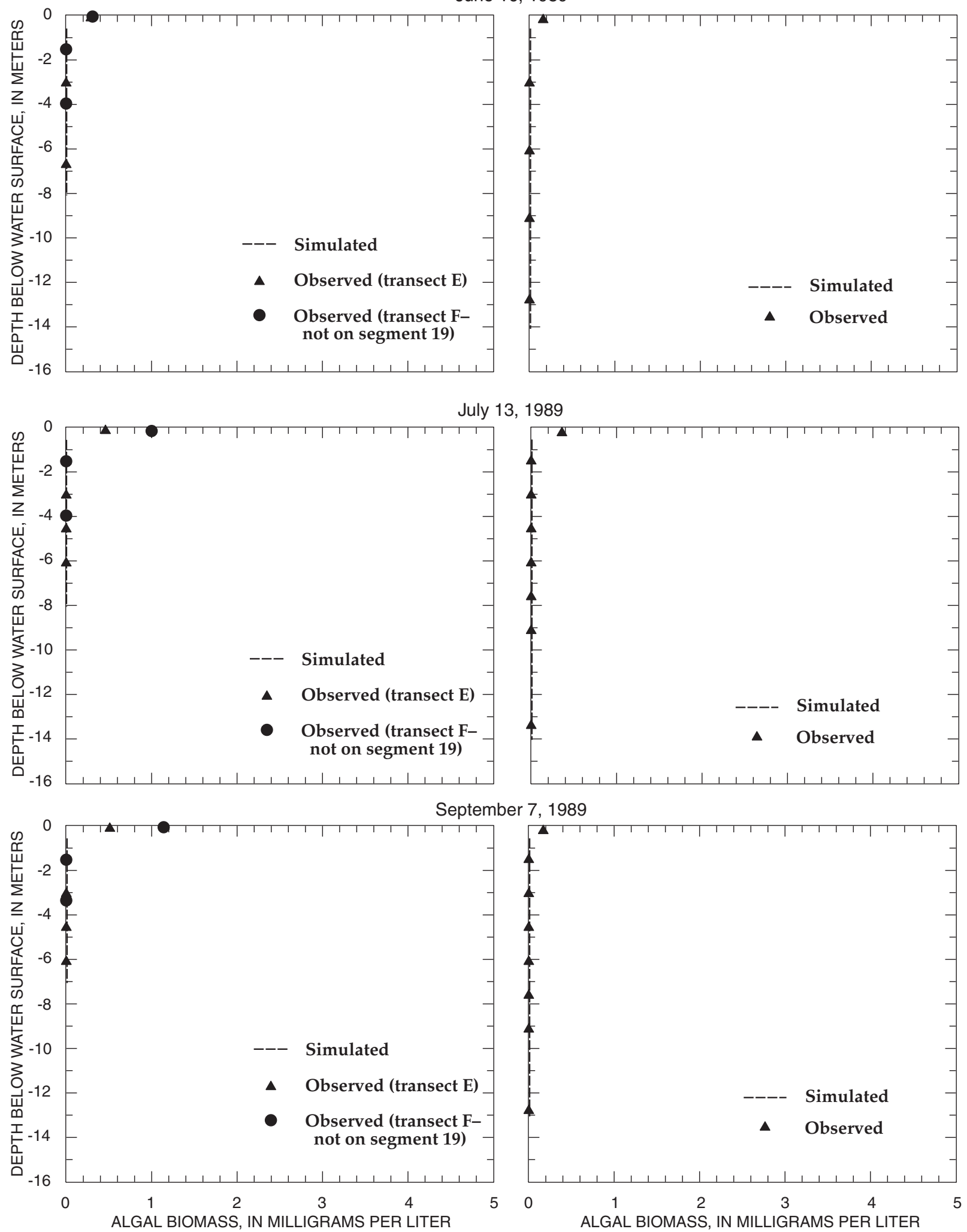

Figure 4j. Algal biomass as computed during model test run at segments 19 and 32 in Lake Houston for selected dates. 

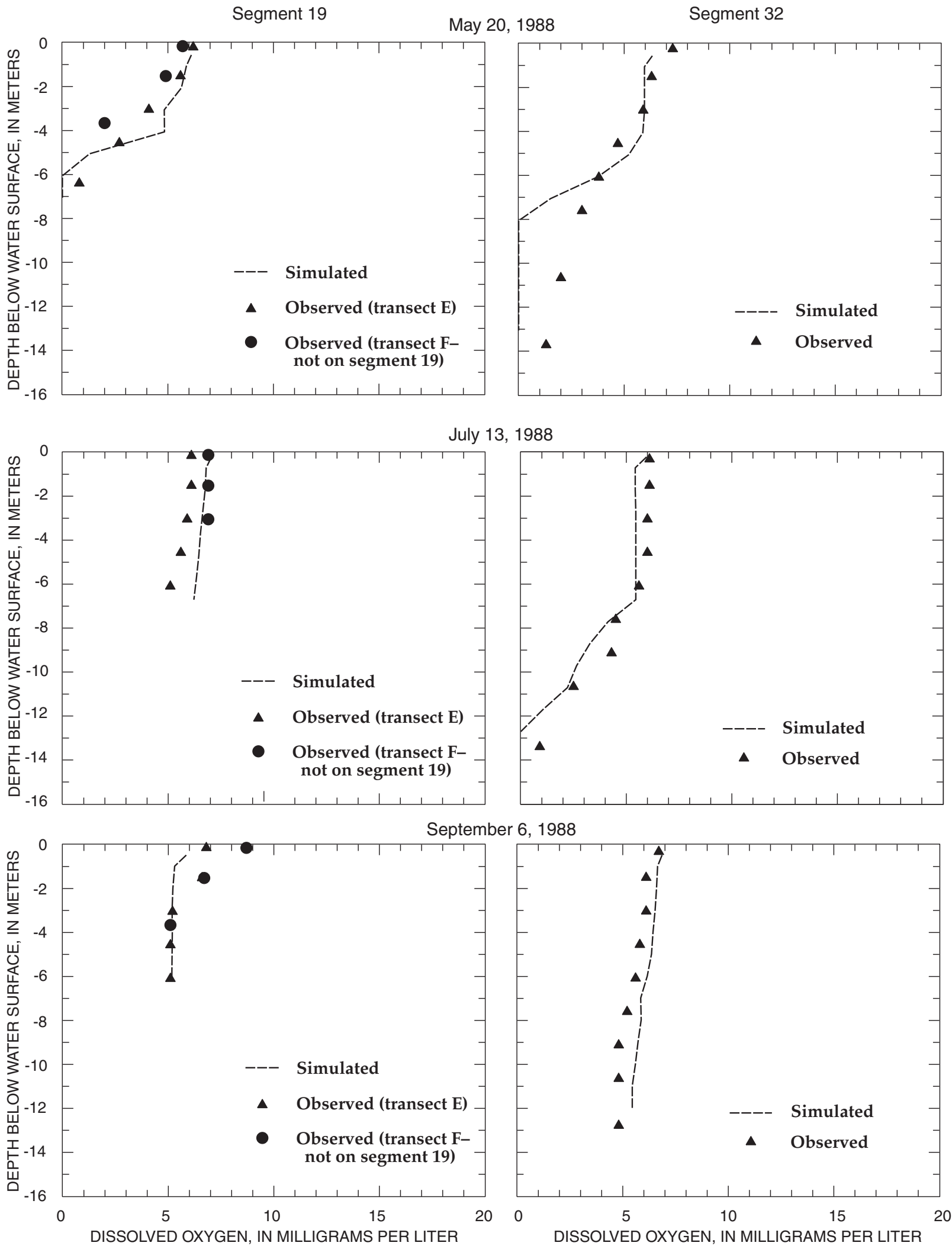

Figure 4k. Dissolved oxygen as computed during model calibration at segments 19 and 32 in Lake Houston for selected dates. 

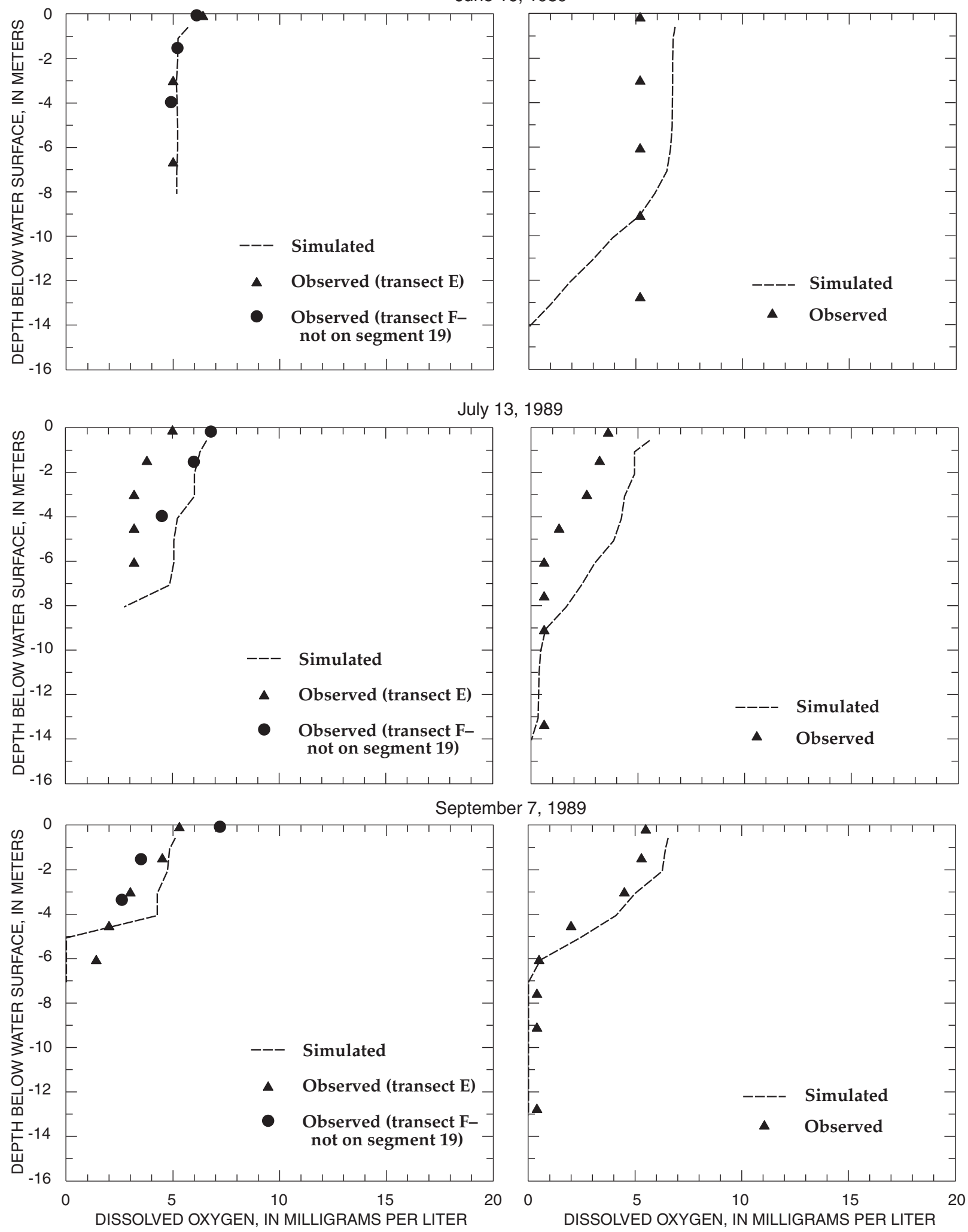

Figure 4l. Dissolved oxygen as computed during model test run at segments 19 and 32 in Lake Houston for selected dates. 

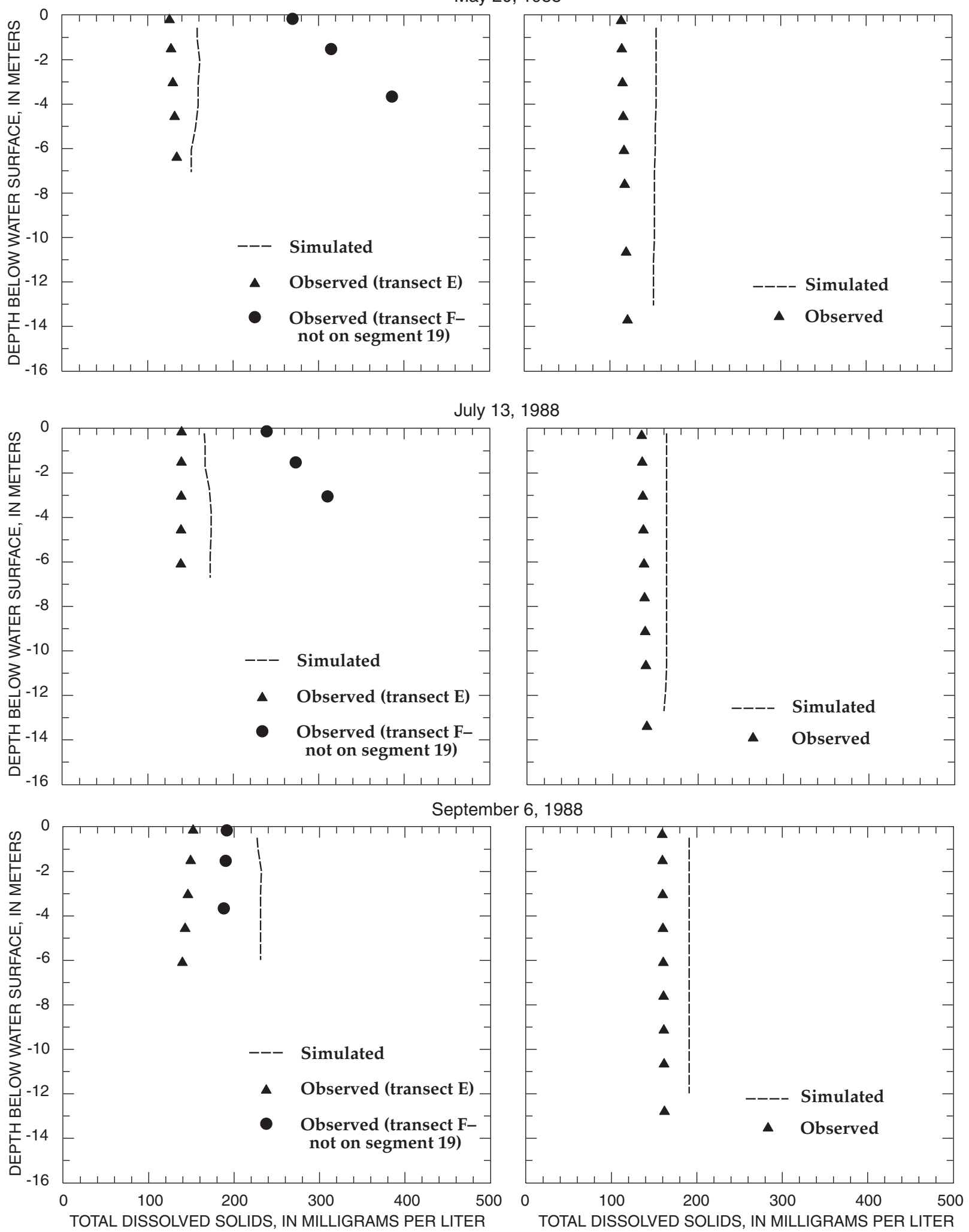

Figure $4 \mathrm{~m}$. Total dissolved solids as computed during model calibration at segments 19 and 32 in Lake Houston for selected dates. 

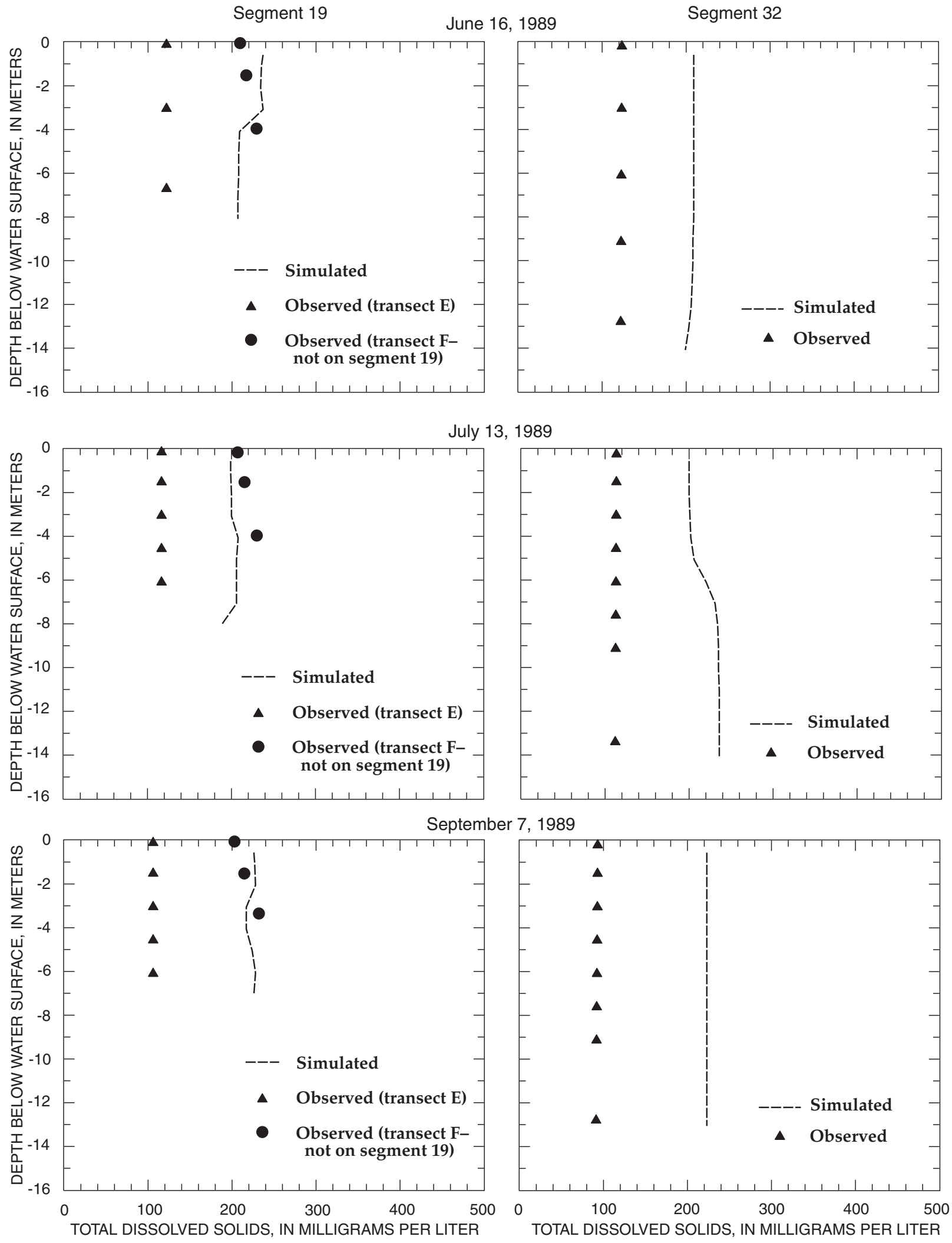

Figure 4n. Total dissolved solids as computed during model test run at segments 19 and 32 in Lake Houston for selected dates. 

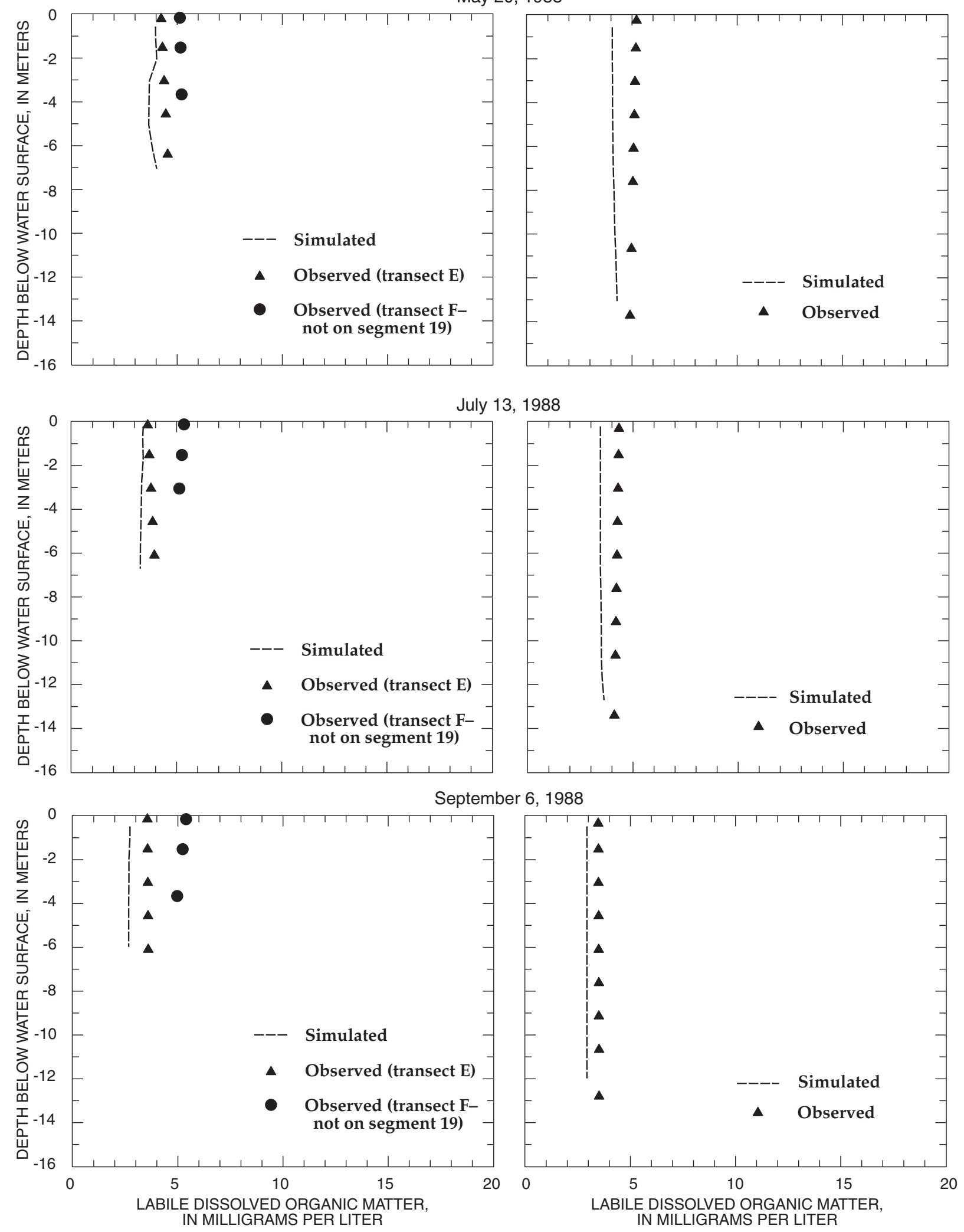

Figure 4o. Labile dissolved organic matter as computed during model calibration at segments 19 and 32 in Lake Houston for selected dates. 

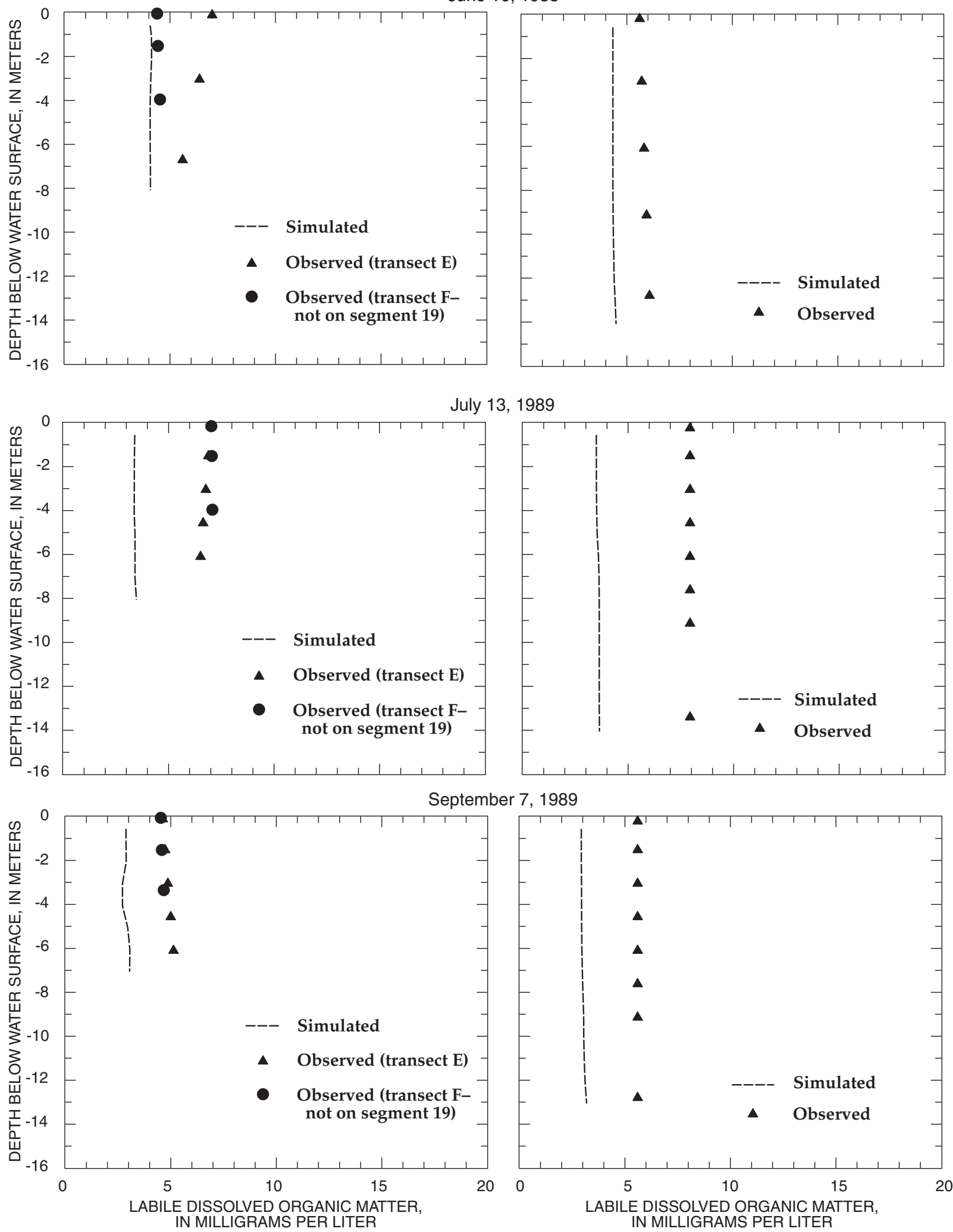

Figure 4p. Labile dissolved organic matter as computed during model test run at segments 19 and 32 in Lake Houston for selected dates. 

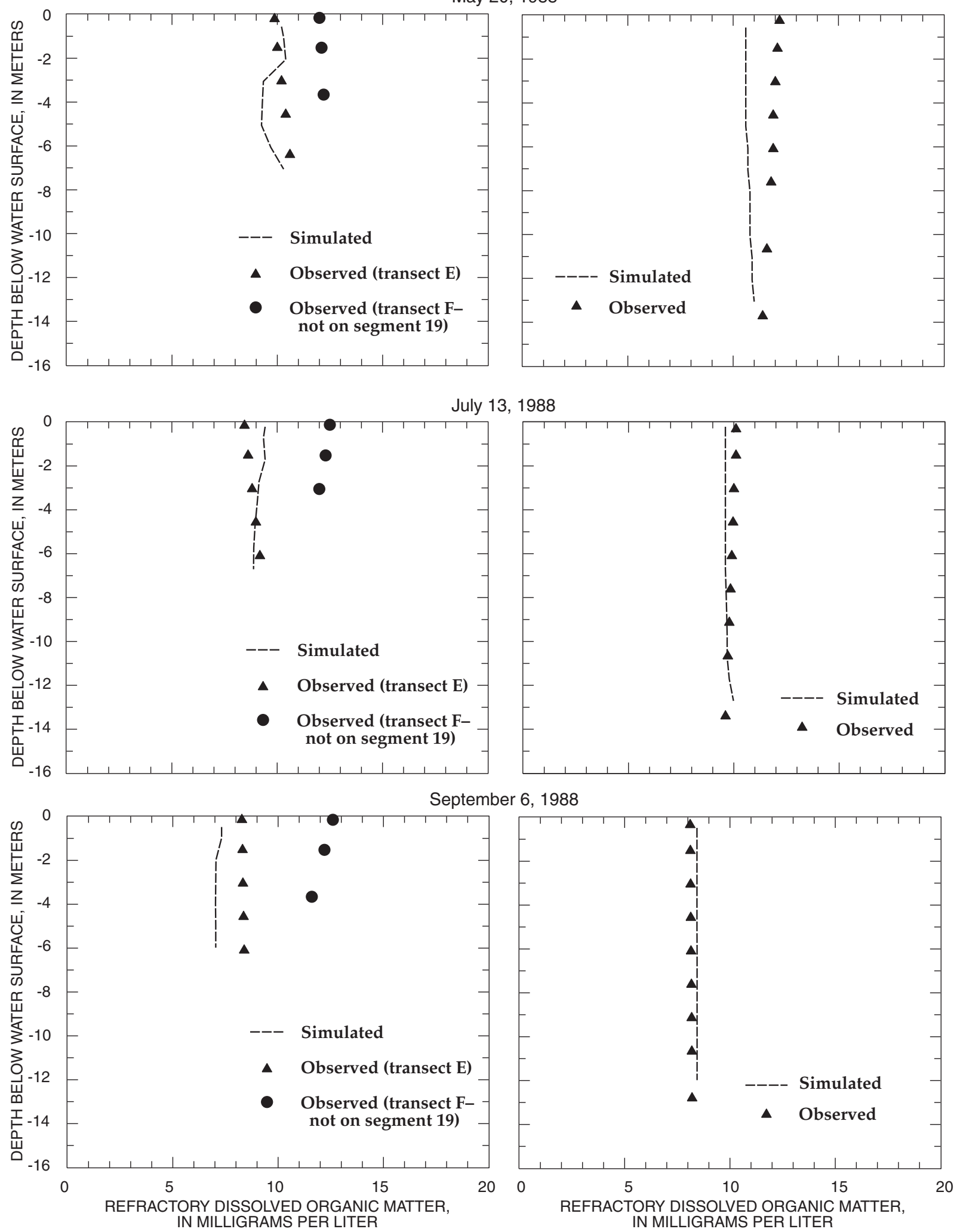

Figure 4q. Refractory dissolved organic matter as computed during model calibration at segments 19 and 32 in Lake Houston for selected dates. 

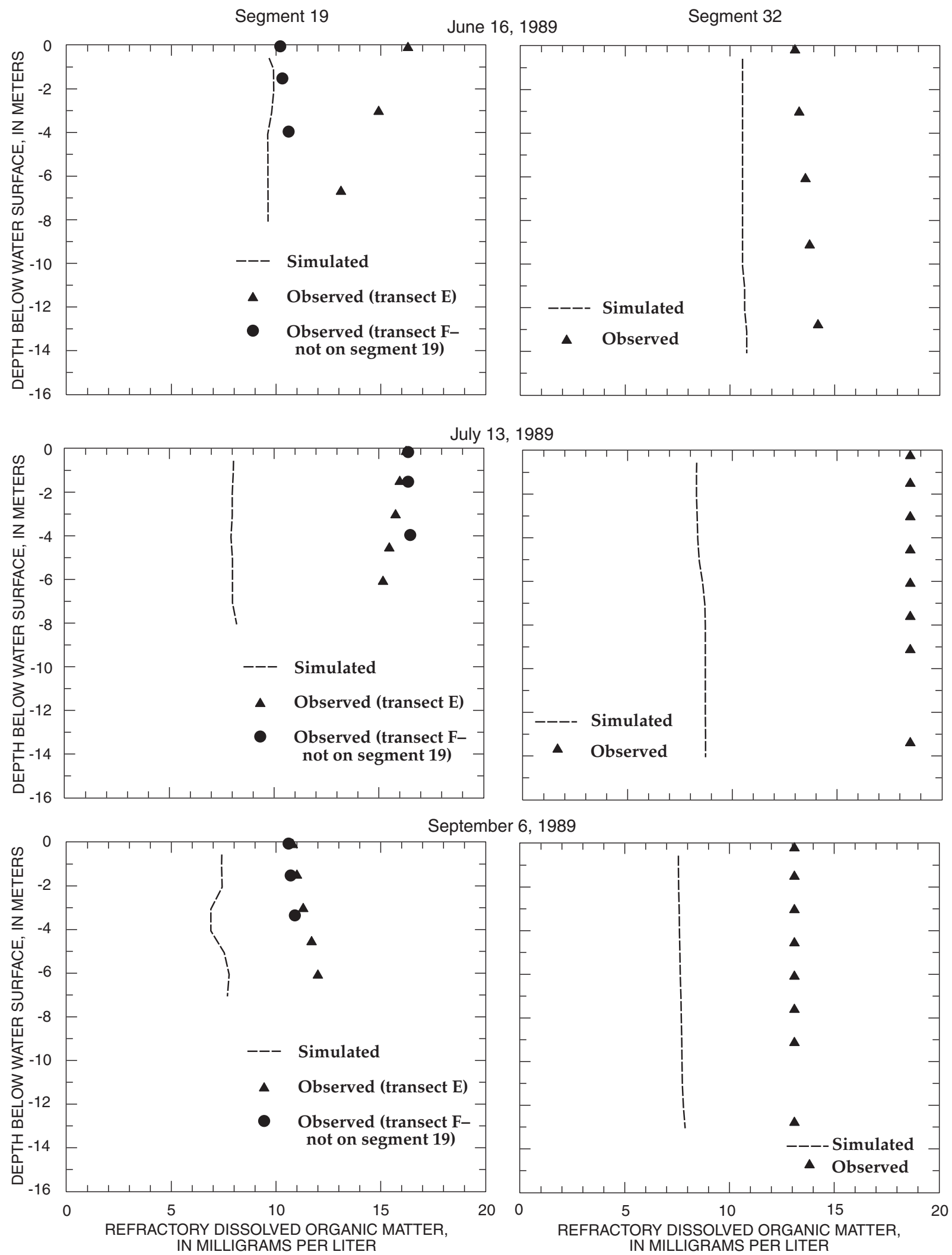

Figure 4r. Refractory dissolved organic matter as computed during model test run at segments 19 and 32 in Lake Houston for selected dates. 

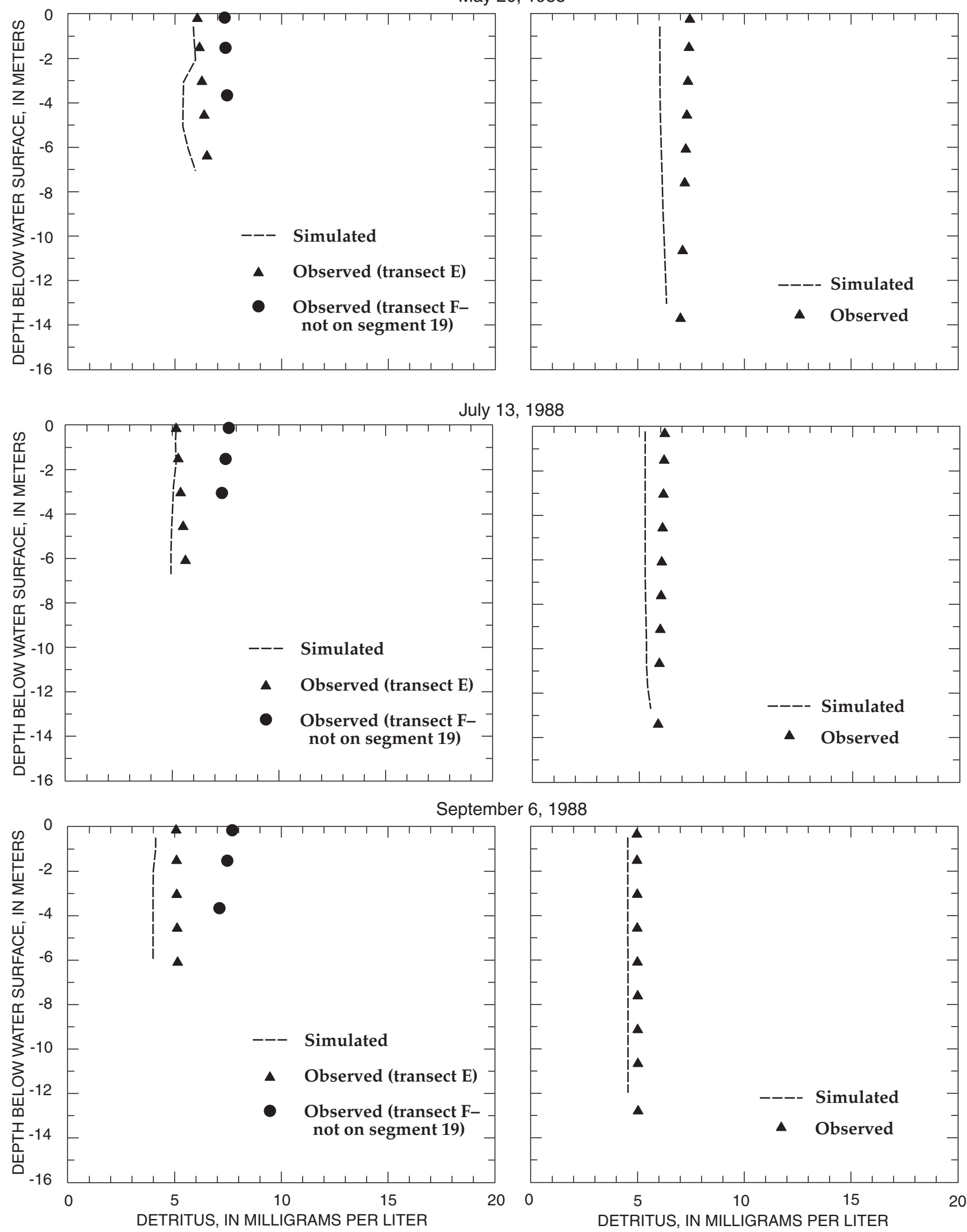

Figure 4s. Detritus as computed during model calibration at segments 19 and 32 in Lake Houston for selected dates. 
Segment 19

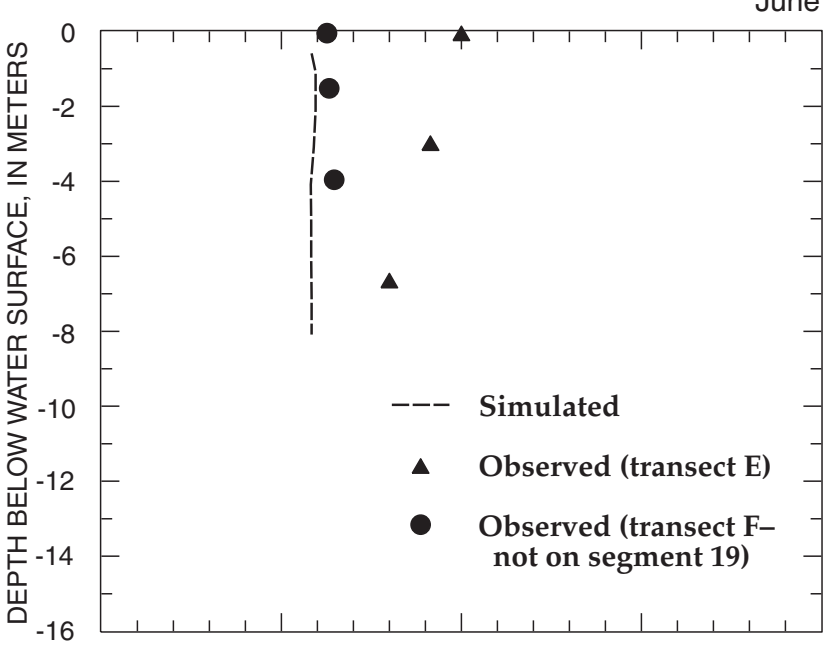

July 13, 1989

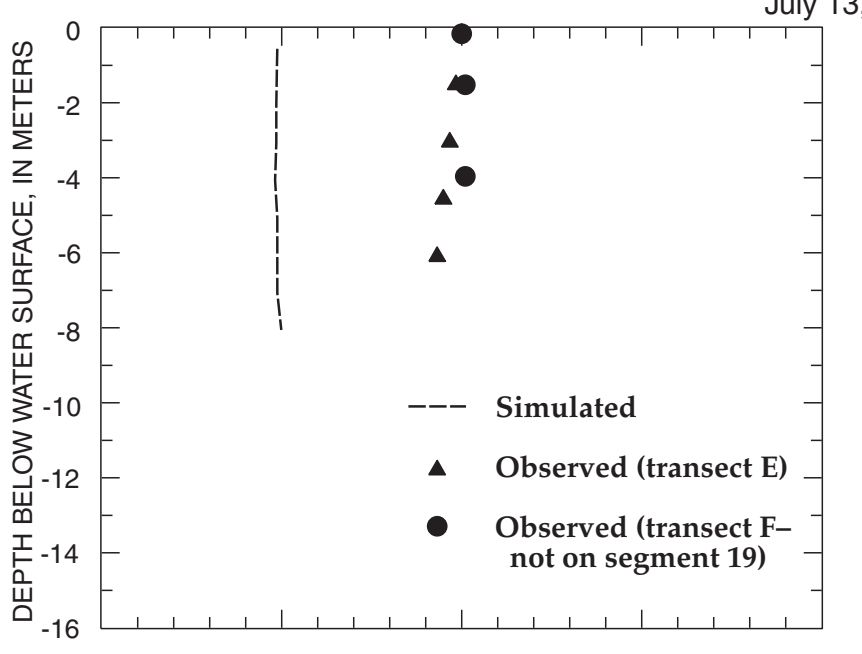

September 7, 1989
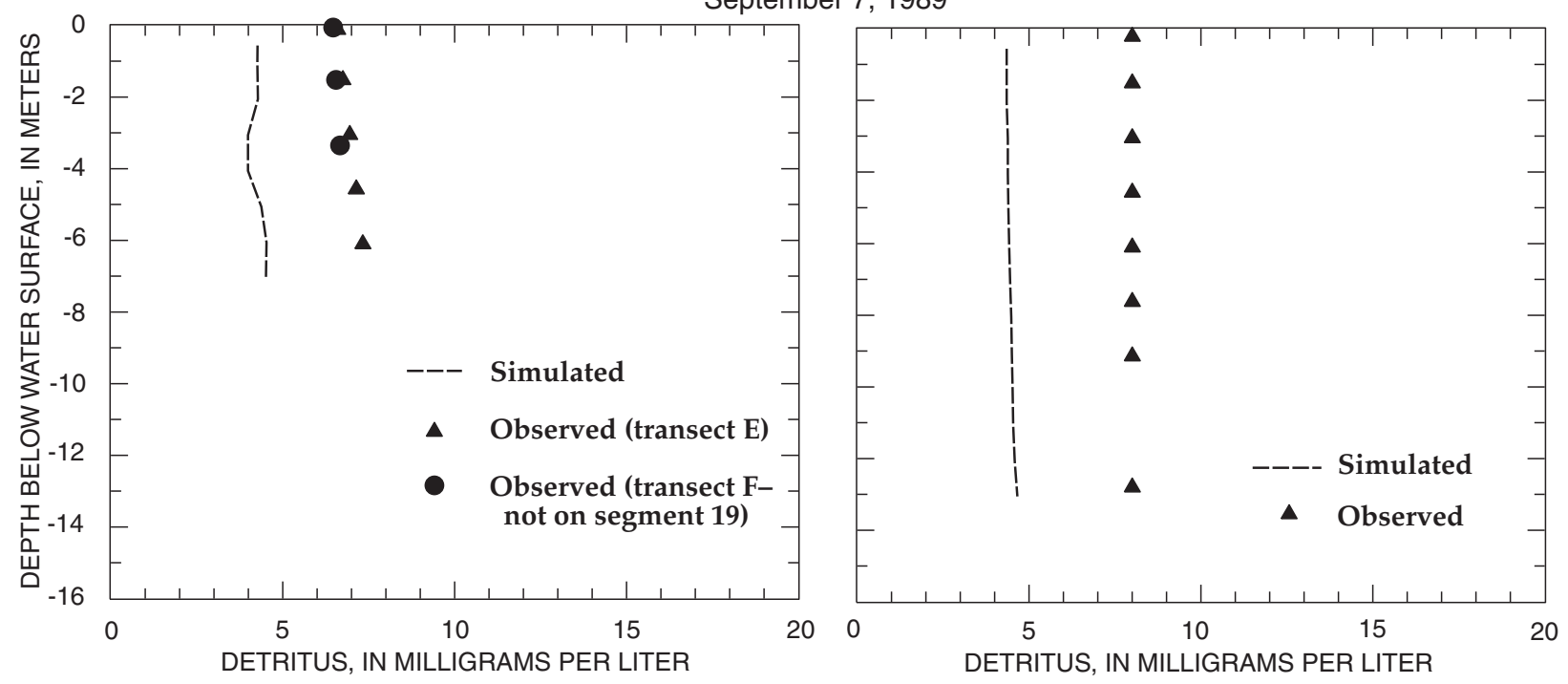

Figure 4t. Detritus as computed during model test run at segments 19 and 32 in Lake Houston for selected dates. 

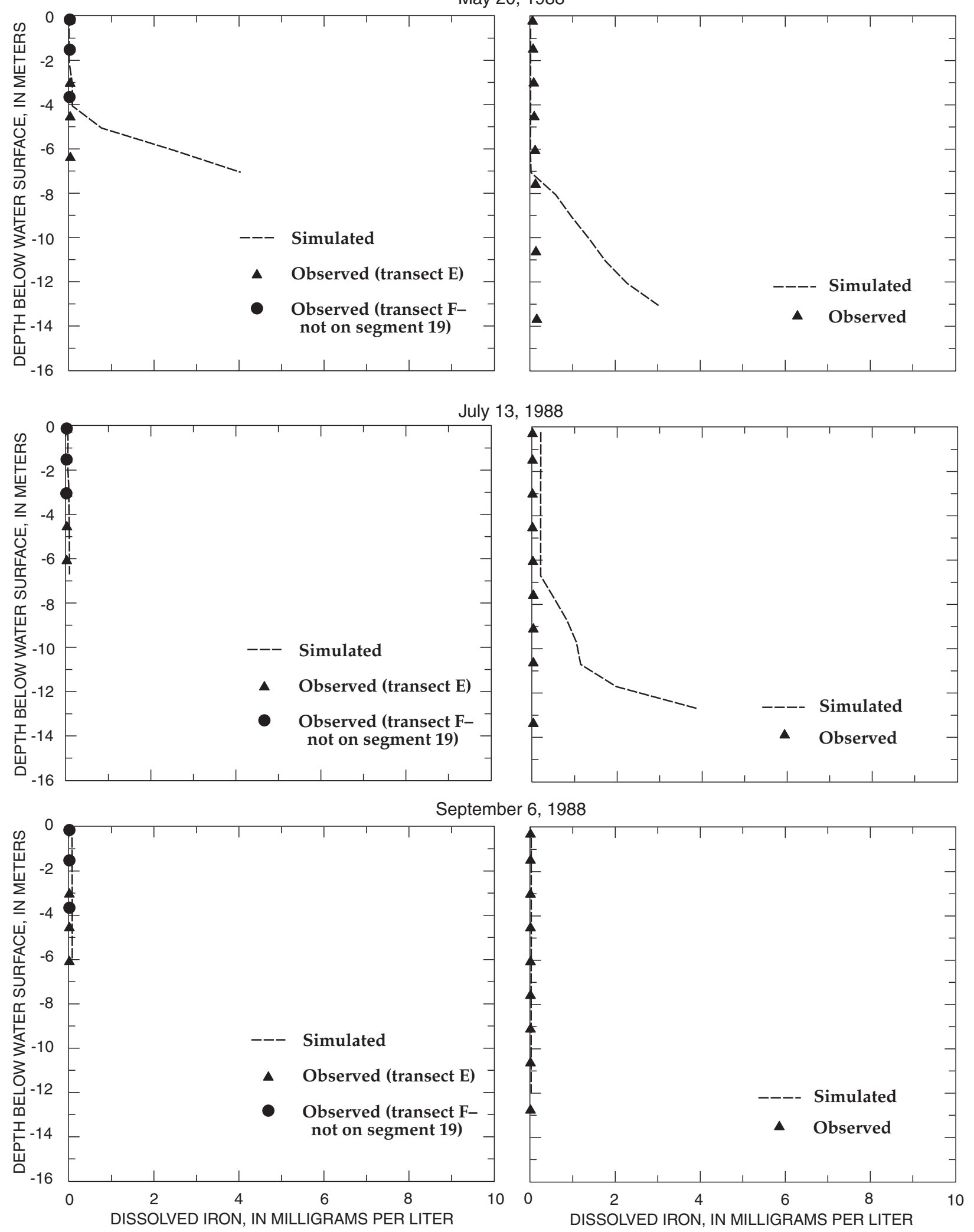

Figure 4u. Dissolved iron as computed during model calibration at segments 19 and 32 in Lake Houston for selected dates. 

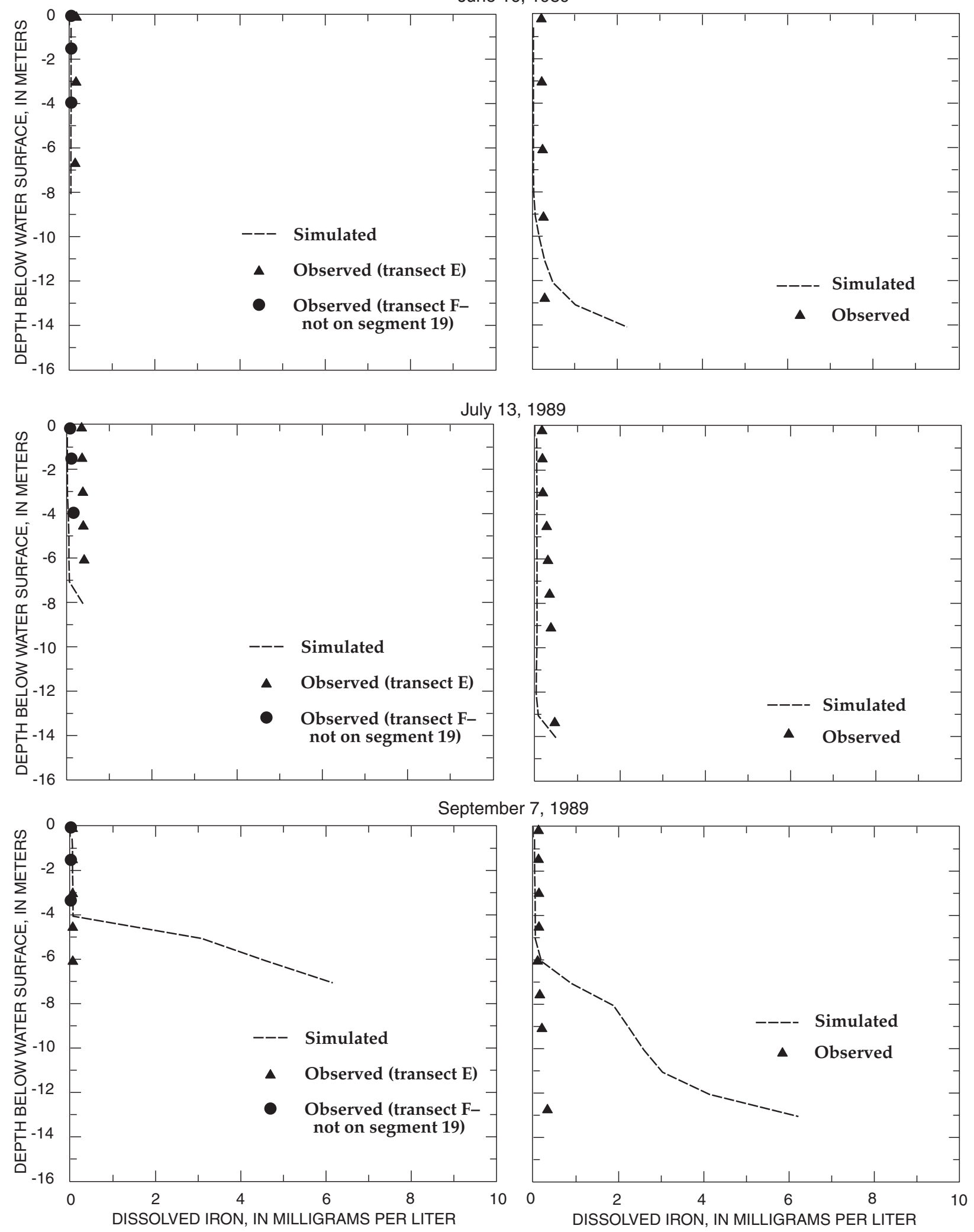

Figure 4v. Dissolved iron as computed during model test run at segments 19 and 32 in Lake Houston for selected dates. 

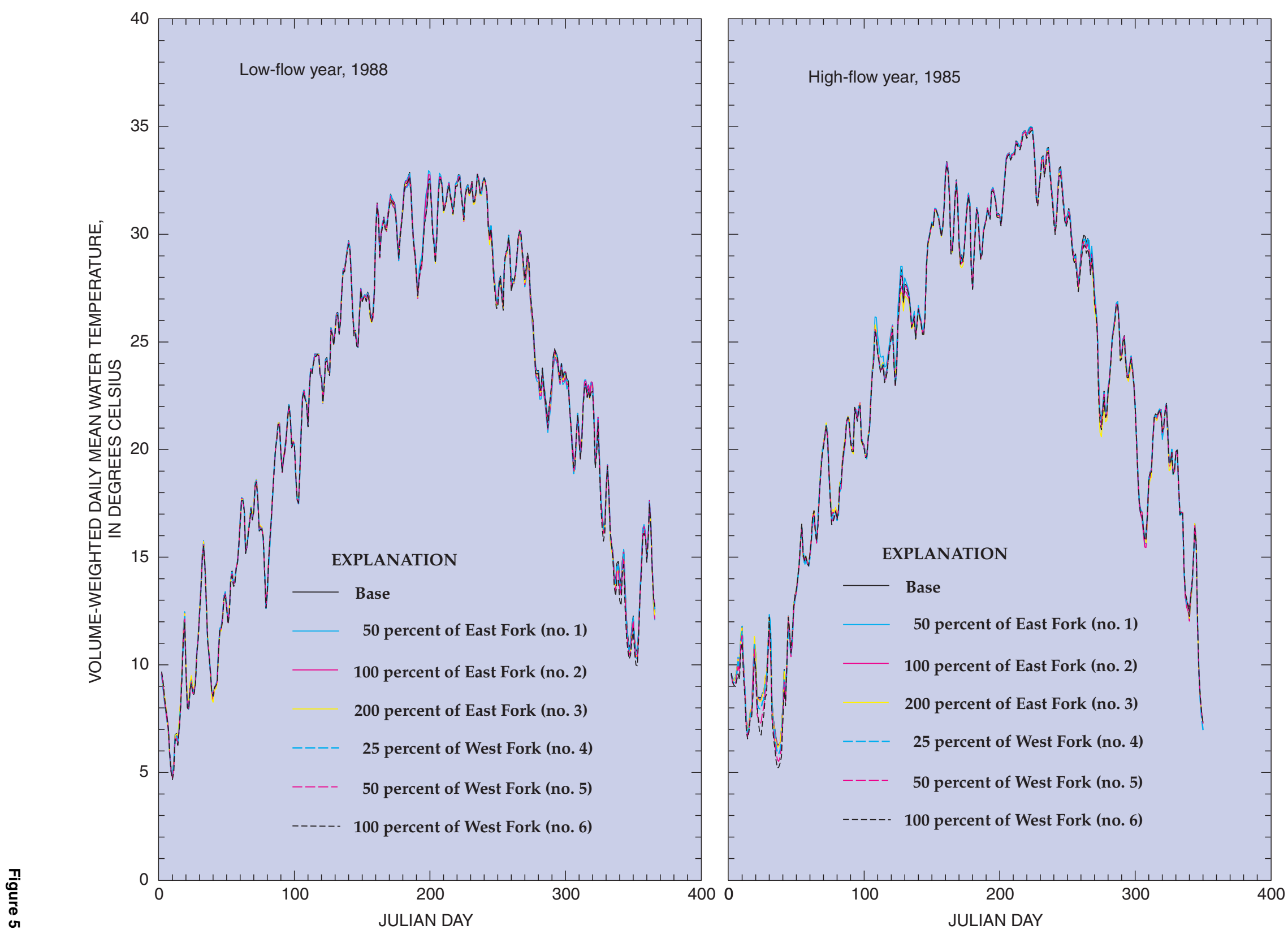

Figure 5a. Simulated volume-weighted daily mean water temperature for segment 32 in Lake Houston using base dataset and six water-transfer of scenarios for low- and high-flow years. 

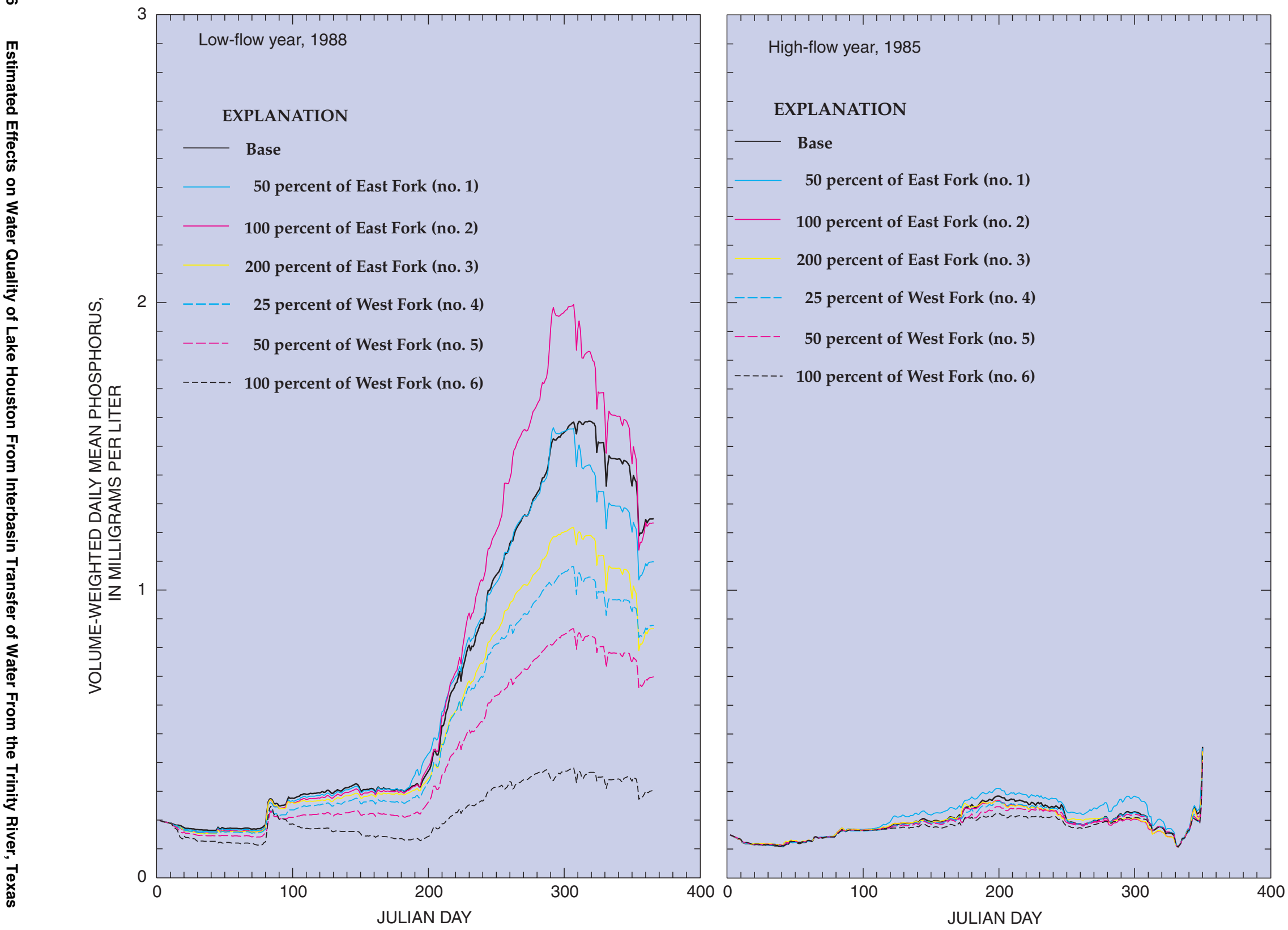

Figure 5b. Simulated volume-weighted daily mean phosphorus for segment 32 in Lake Houston using base dataset and six water-transfer scenarios for low- and high-flow years. 

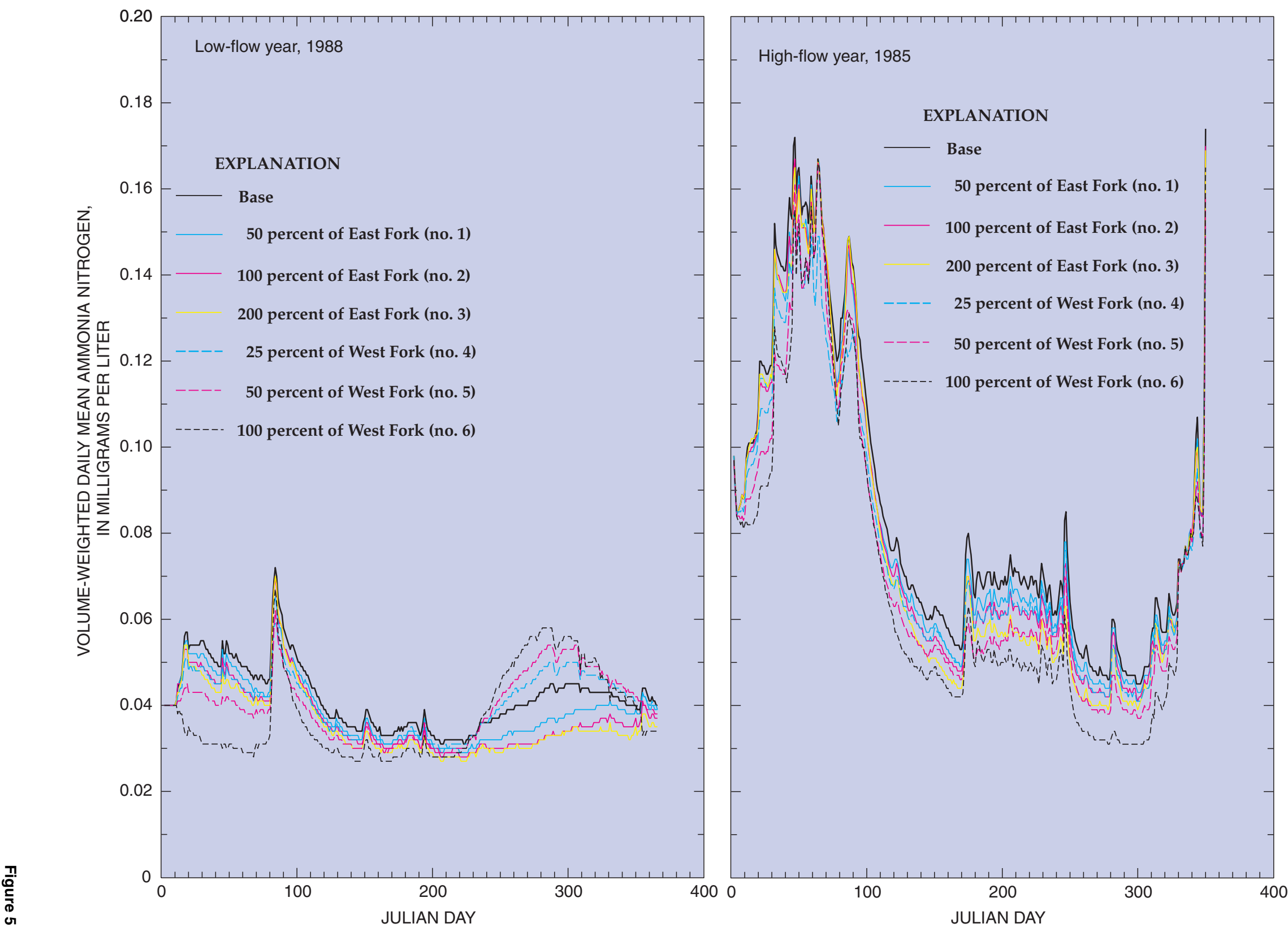

Figure 5c. Simulated volume-weighted daily mean ammonia nitrogen for segment 32 in Lake Houston using base dataset and six water-transfer i scenarios for low- and high-flow years. 

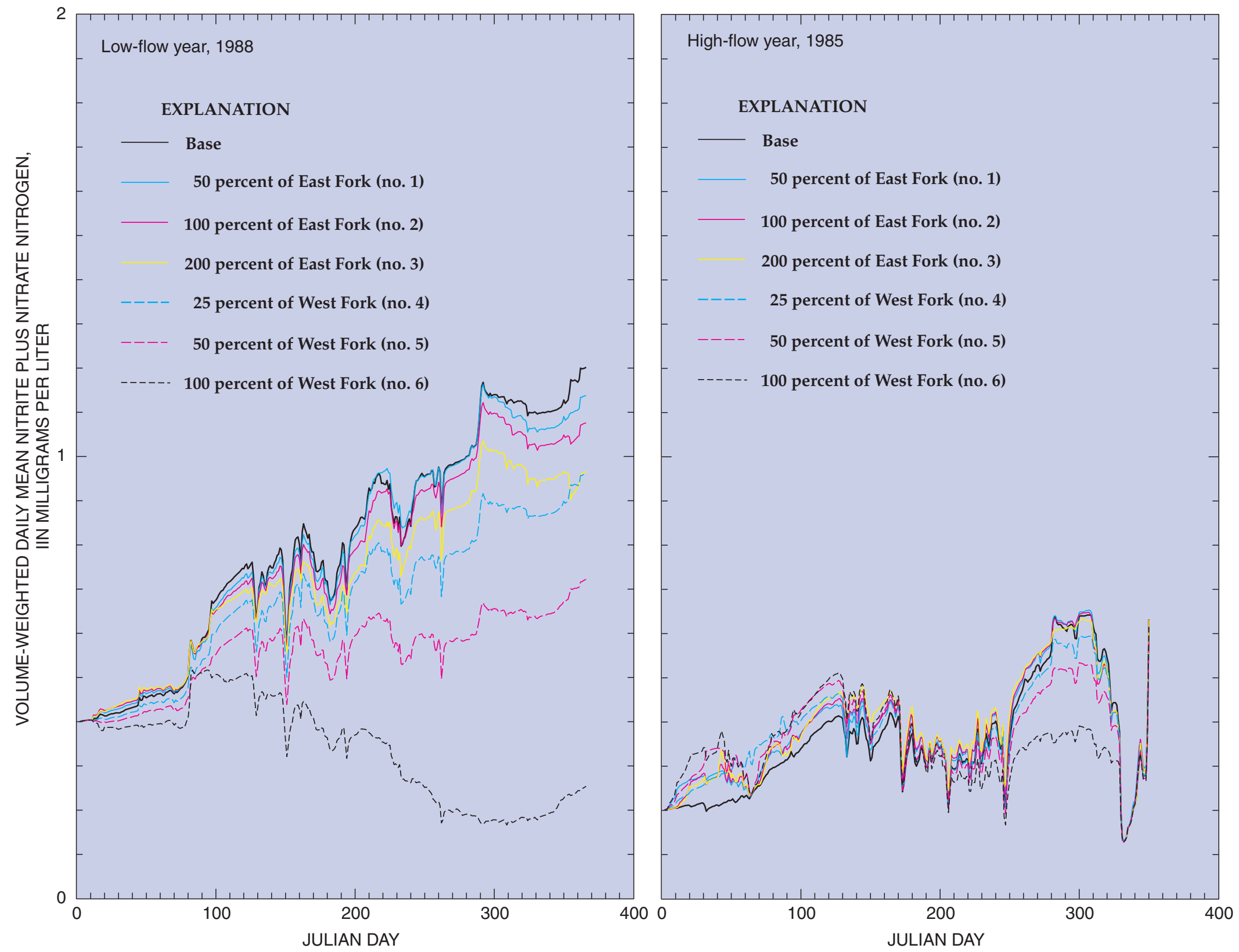

Figure 5d. Simulated volume-weighted daily mean nitrite plus nitrate nitrogen for segment 32 in Lake Houston using base dataset and six watertransfer scenarios for low- and high-flow years. 

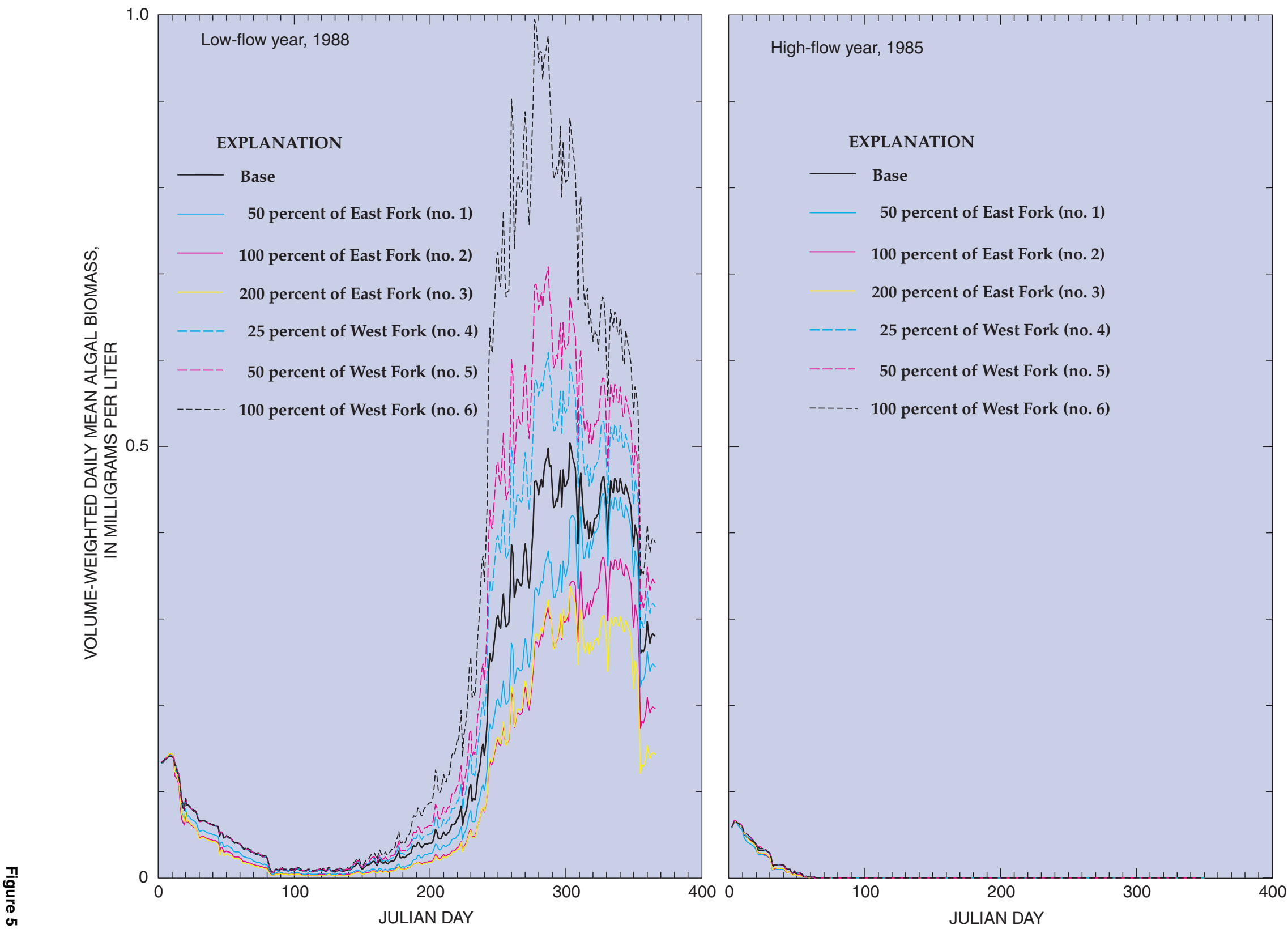

Figure 5e. Simulated volume-weighted daily mean algal biomass for segment 32 in Lake Houston using base dataset and six water-transfer $\stackrel{\bullet}{0}$ scenarios for low- and high-flow years. 

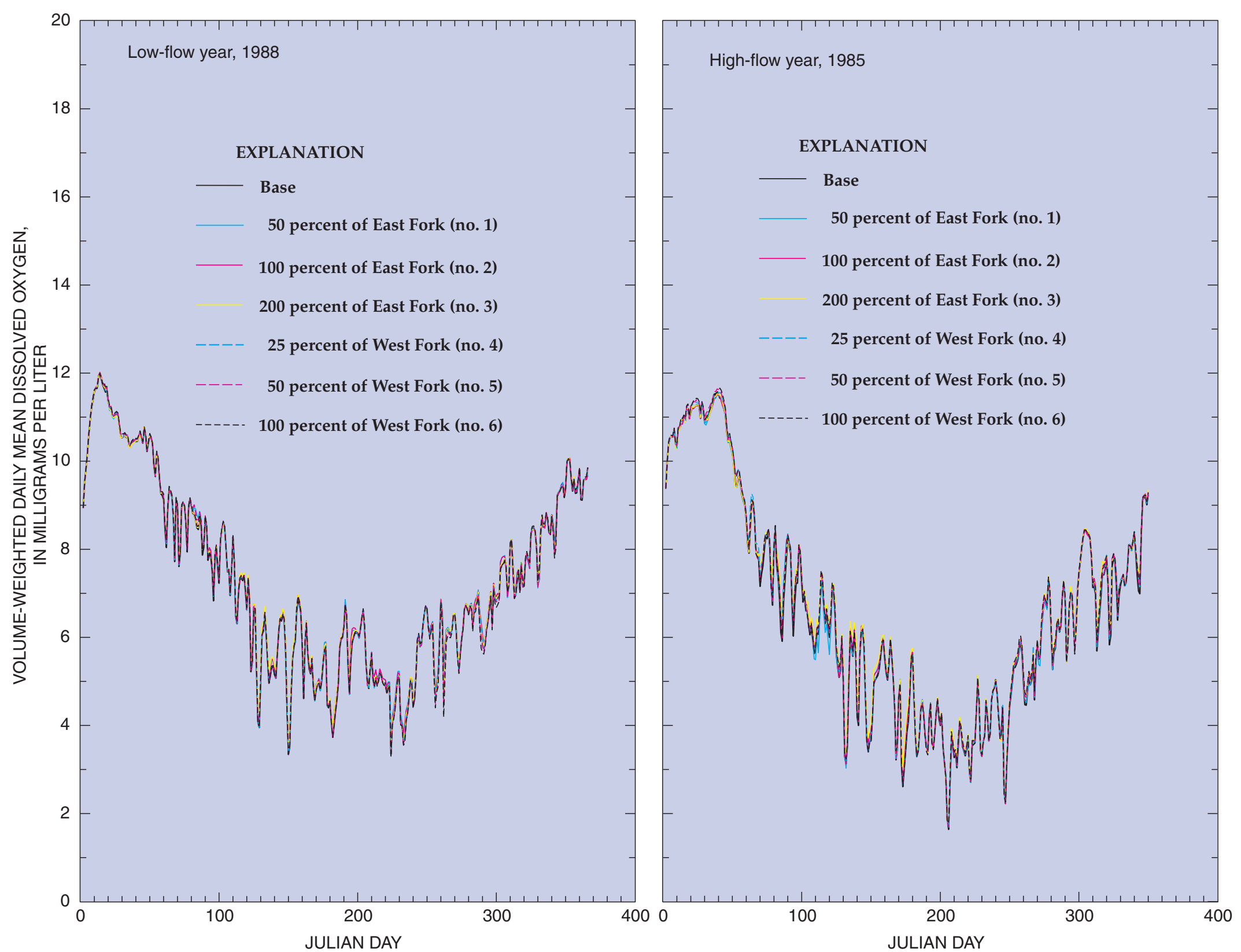

Figure 5f. Simulated volume-weighted daily mean dissolved oxygen for segment 32 in Lake Houston using base dataset and six water-transfer scenarios for low- and high-flow years. 